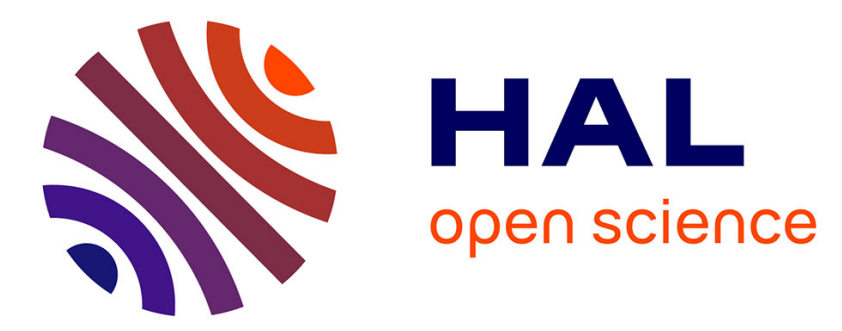

\title{
Heterogeneity of plural forms : a revised transaction cost approach
}

Paula Schnaider

\section{To cite this version:}

Paula Schnaider. Heterogeneity of plural forms : a revised transaction cost approach. Economics and Finance. Université Panthéon-Sorbonne - Paris I; Universidade de São Paulo (Brésil), 2016. English. NNT : 2016PA01E010 . tel-01820611

\section{HAL Id: tel-01820611 https://theses.hal.science/tel-01820611}

Submitted on 22 Jun 2018

HAL is a multi-disciplinary open access archive for the deposit and dissemination of scientific research documents, whether they are published or not. The documents may come from teaching and research institutions in France or abroad, or from public or private research centers.
L'archive ouverte pluridisciplinaire $\mathbf{H A L}$, est destinée au dépôt et à la diffusion de documents scientifiques de niveau recherche, publiés ou non, émanant des établissements d'enseignement et de recherche français ou étrangers, des laboratoires publics ou privés. 
Université de Paris I Panthéon-Sorbonne \& Universidade de São Paulo

U.F.R. de Sciences Economiques

Centre d'Economie de la Sorbonne (CES) \& Center for Organization Studies (CORS USP)

$\mathrm{N}^{\mathrm{o}}$ attribué par la bibliothèque

\title{
THÈSE
}

présentée en régime de cotutelle pour le grade de

Docteur ès sciences économiques

\section{HÉTÉROGÉNÉITÉ DES FORMES PLURIELLES: UNE APPROCHE PAR LES COÛTS DE TRANSACTION REVISÉE/ HETEROGENEITY OF PLURAL FORMS: A REVISED TRANSACTION COST APPROACH}

\author{
présentée et soutenue publiquement le 22 janvier 2016 \\ par \\ Paula Sarita Bigio Schnaider \\ Co-Directeurs de thèse: \\ Claude Ménard et Maria Sylvia Macchione Saes
}

\begin{tabular}{lll} 
& \multicolumn{1}{c}{ Jury } & \\
Mme. Annie Royer & Professeure à l'Université Laval (Québec) & Présidente \\
M. Decio Zylbersztajn & Professeur à l'Université de Sao Paulo & Rapporteur \\
M. Emmanuel Raynaud & Directeur de Recherche à l'INRA & Rapporteur \\
M. Sandro Cabral & Professeur à l'Université Fédérale de Bahia & Suffragant \\
M. Claude Ménard & Professeur à l'Université Paris 1 (Panthéon-Sorbonne) & Co-Directeur \\
Mme. Maria Sylvia Macchione Saes & Professeure à l'Université de Sao Paulo & Co-Directrice
\end{tabular}


L'UNIVERSITÉ PARIS 1 n'entend donner aucune approbation ou improbation aux opinions émises dans cette thèse. Ces opinions doivent être considérées comme propres à leur auteur. 


\section{Table of Contents}

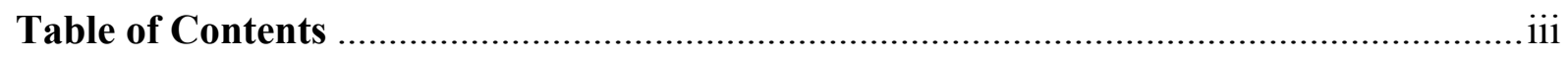

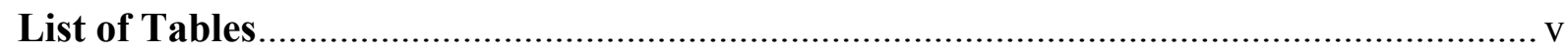

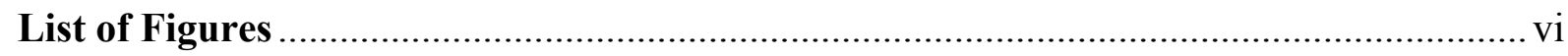

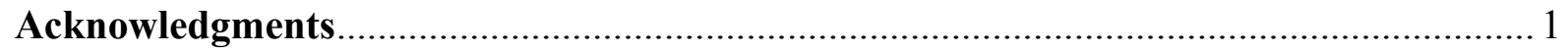

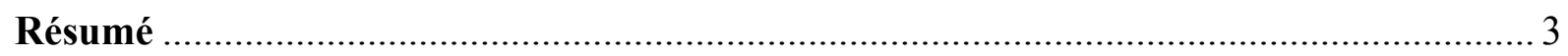

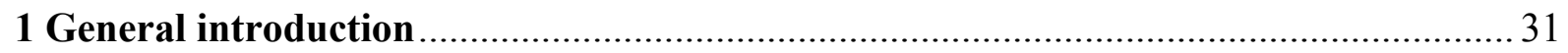

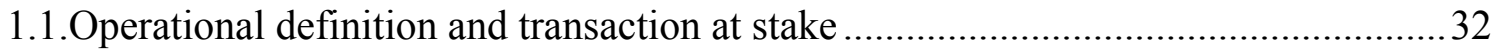

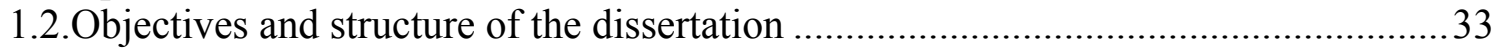

1.3.The building of this dissertation and the English language .................................... 38

2 Organization theory and plural forms: past, present and future directions ................. 39

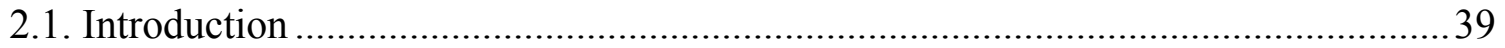

2.2. A brief literature overview - an exploratory bibliometric survey ............................42

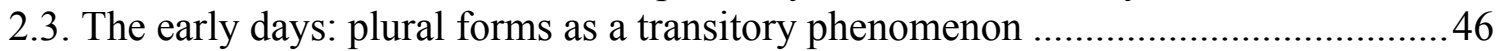

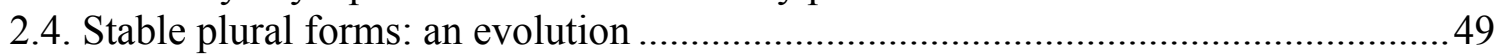

2.5. Organization Theory and plural forms: a challenge? ...........................................53

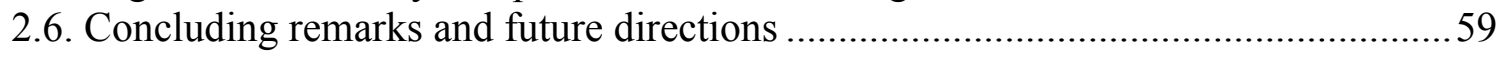

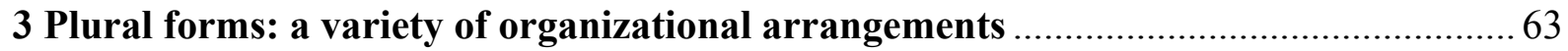

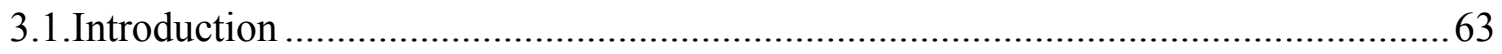

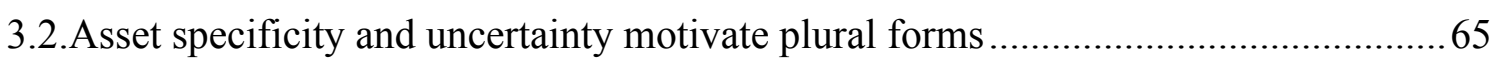

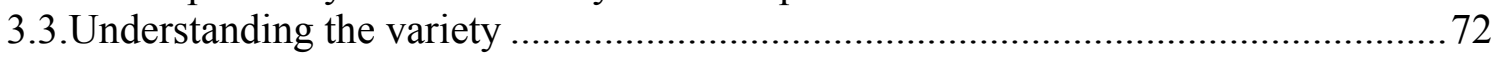

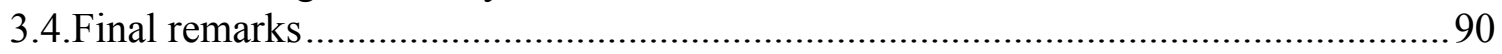

4 Predicting plural forms and diversified organizational arrangements with the combination of asset specificity and uncertainty: a case study in Brazil ........................ 93

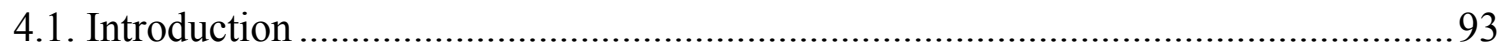

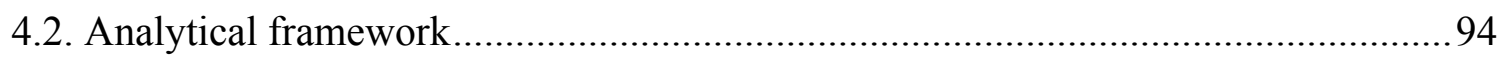

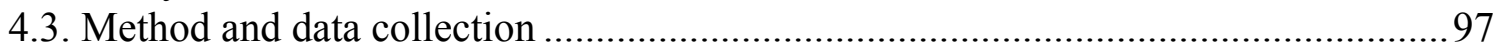

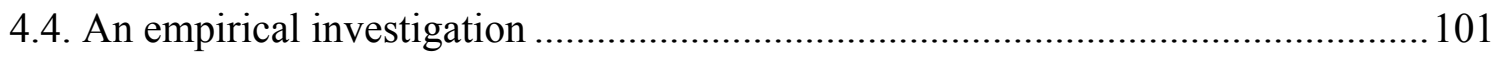

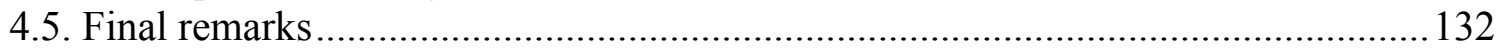


5 Heterogeneous plural forms under uncertainty: an empirical investigation 135

5.1. Introduction

5.2. Theoretical background......

5.3. Method and data

5.4. Main findings and discussion

5.5. Final remarks

6 Conclusion 


\section{List of Tables}

Table 1. 20 most highly cited publications between 1970 and 2014

Table 2. Leading Plural Form explanations in franchising ${ }^{\mathrm{a}}$ and some well known papers subscribing to each of them

Table 3. Leading Plural Form explanations in other sectors and some well known papers

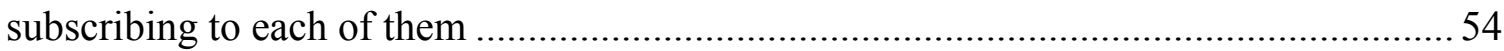

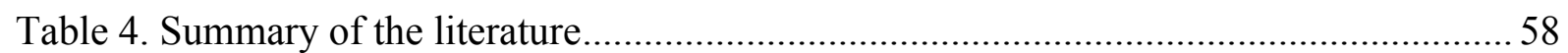

Table 5. Summary of our hypotheses relative to performance assessment uncertainty ...........85

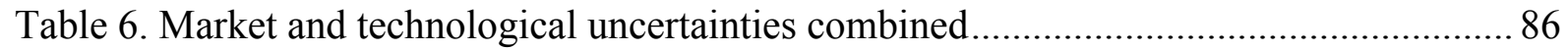

Table 7. Market or technological uncertainties and performance assessment uncertainty

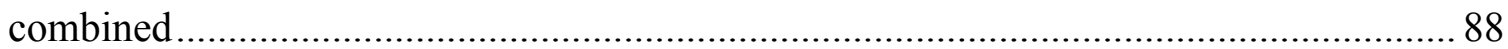

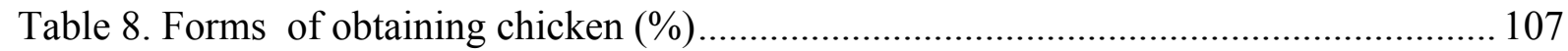

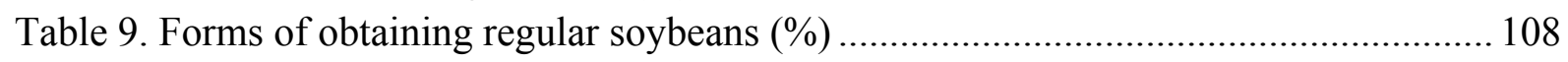

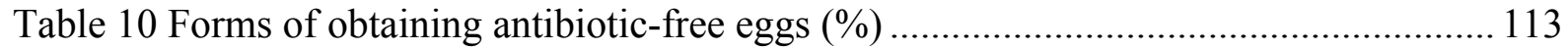

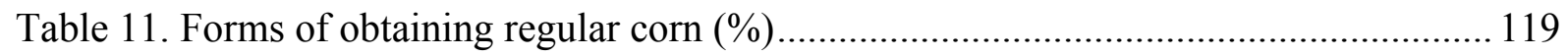

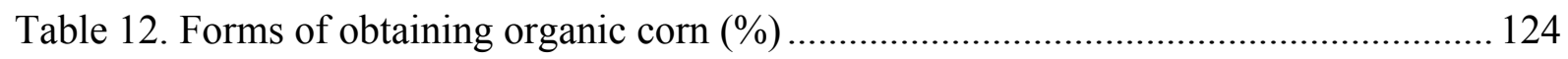

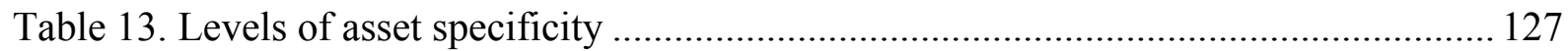

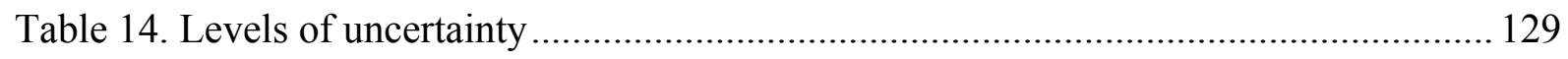

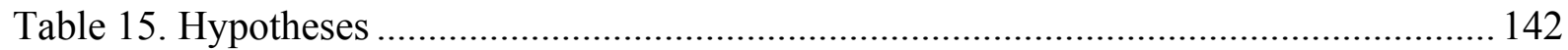

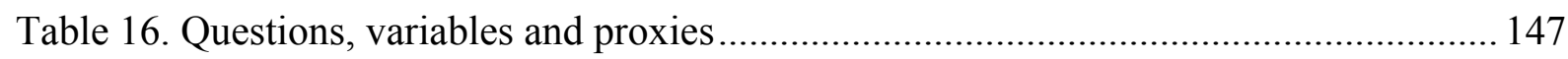

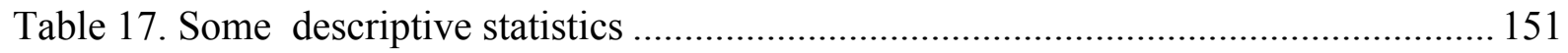

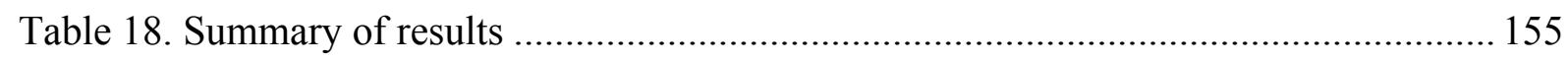

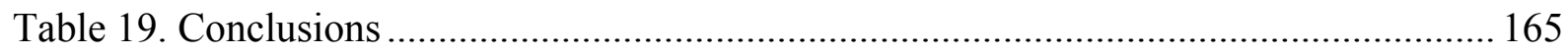

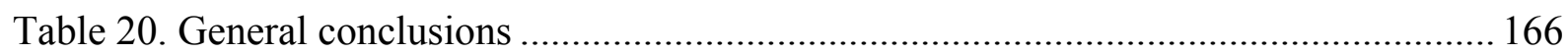




\section{List of Figures}

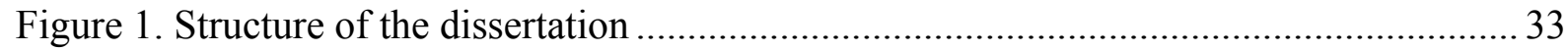

Figure 2. Schematic representation of the plurality of governance structures in the

procurement of inputs (A) and on the distribution of products (B) .............................. 41

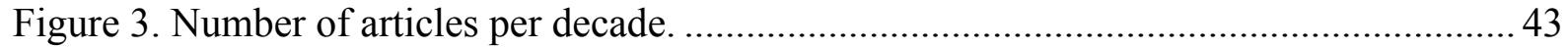

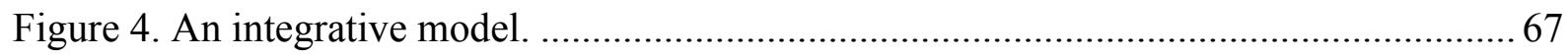

Figure 5. An integrative perspective of asset specificity and uncertainty and our contribution

Figure 6. Embedded case study - subunits of analysis in the Korin case. ............................. 99

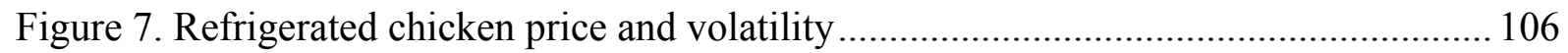

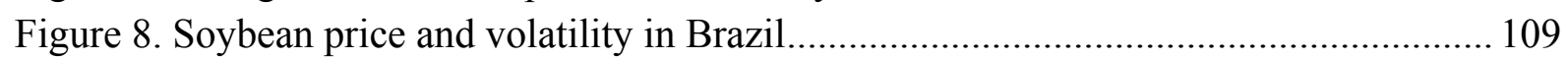

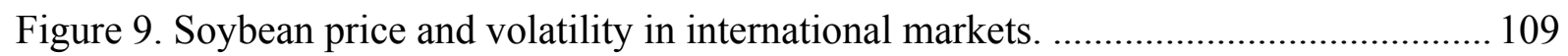

Figure 10. Schematic representation of the stages of the egg supply-chain which are controlled by Korin (green dotted line) and by its suppliers (black dotted line)........... 114

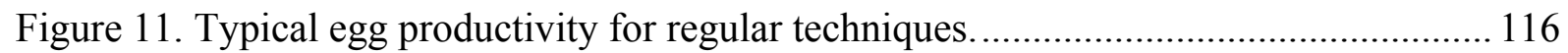

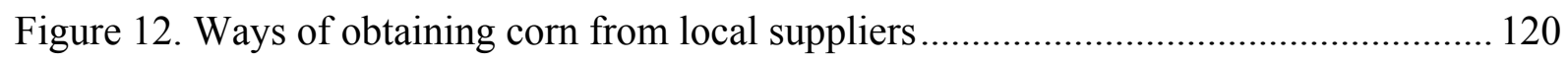

Figure 13 - Daily nominal corn price index in US Dollars. .............................................. 121

Figure 14. An empirical illustration of the integrative framework.131

Figure 15. An integrative model of asset specificity and uncertainty ................................ 137

Figure 16. The transaction at stake: procurement of the main input................................... 145 


\section{Acknowledgments}

The writing of this dissertation involved the interaction with a number of people and institutions to which I wish to express my sincere gratitude. I had the privilege of being formally supervised by not one, but two amazing advisors, with whom I am deeply indebted: Claude Menard and Sylvia Saes. My dual PhD (cotutelle), between the University of Sao Paulo and the University of Paris 1 - Panthéon-Sorbonne, would not have been possible without their kind assistance.

I would like to specially acknowledge Claude Menard for having warmly received me as a $\mathrm{PhD}$ student in Paris and for the valuable comments, advice and teachings during my entire program. I wish to thank Sylvia Saes for kindly introducing me to her research group (CORS) when I was still an undergraduate student. Her sense of humor, guidance, encouragement and support played a key role, especially when I found problems with my work.

I would also like to express my gratitude to Emmanuel Raynaud for having nicely received me at INRA as visiting PhD student and for all our discussions during the writing of this dissertation. I am certain that his advice and him challenging my ideas significantly enhanced the quality of this work.

During my visit to Paris, I also had the opportunity to discuss my research with Niels Peter Mols, whom I wish to thank for taking the time to read my work and comment on some of my ideas. I would also like to thank Carine Staropoli and Patricia Vornetti for providing guidance when I first arrived at Paris 1, and Patricia Perennes and Jean Beuve, who played a key role when I presented my work at the Seminar for Public Economics, Institutions \& Organizations in Paris.

I also had the opportunity to present partial versions of this dissertation at the European School for New Institutional Economics, at the Strategic Management Society Conference, at the Research Workshop on Institutions and Organizations and at the Ronald Coase Institute workshop on Institutional Analysis, having very much benefited from the comments by Birger Wernerfelt, Sandro Cabral, Guilherme Fowler, among other distinguished scholars.

I wish to thank my professors at the University of Sao Paulo for their valuable teachings during my undergraduate and graduate studies. I am particularly indebted to Decio Zylbersztajn for encouraging me to pursue the dual degree.

I must also express my gratitude to Luiz Carlos Dematte Filho, who provided me with valuable information from Korin.

My dear friends from the Center for Organization Studies (CORS) at USP also deserve a special recognition - Anders Fredriksson, Bruno Varella, Camila Dias, Carol Foscaches, Carol Moron, Eder Carvalho, Fabio Dolnikoff, Fernando Rocha, Fernando Kolya, Kassia Watanabe, Leandro Pongeluppe, Matheus Magalhães, Sara Gurfinkel, Thiago Carvalho, Yasser Salleh. Many thanks for the comments on this dissertation and for the laughs that made the writing process more pleasant and fun. Many thanks to Neca for helping me whenever I needed. 
I would like to express my gratitude to my parents, grandparents and husband, for always encouraging me to go further

Finally, I would like to thank the Sao Paulo State Research Foundation (FAPESP) for the financial support and both the University of Paris 1 and the University of Sao Paulo (where I completed my undergraduate and graduate studies) for making the cotutelle possible. 


\section{Résumé}

\section{Contexte}

Cette thèse a été écrite dans le contexte d'une convention de cotutelle entre l'Université de São Paulo et l'Université de Paris I - Panthéon - Sorbonne. L'accord m'a permis de développer une partie considérable de ce travail lors de mon séjour de l'année universitaire 2013 - 2014 à Paris grâce au support financier de la Fondation d'Aide à la Recherche de 1'État de São Paulo (FAPESP). Dans le but de faciliter ma communication envers les Français et les Brésiliens, j'ai été amené à rédiger ma thèse en anglais.

\section{Le sujet et la motivation}

Cette thèse analyse une importante régularité empirique, observable mais portant des étiquettes variées dans la littérature théorique: Formes Plurielles (Bradach \& Eccles, 1989; Menard, 2013), intégration effilée (Harrigan, 1983), double distribution (Dutta, Bergen, Heide \& John, 1995; Bai \& Tao, 2000; Mols, 2000; Penard, Raynaud \& Saussier, 2003), approvisionnements simultanés (Parmigiani, 2007; Mols, 2010), approvisionnement pluriel (Puranam, Gulati \& Bhattacharya, 2013; Krzeminska, Hoetker \& Mellewigt, 2014), voies de distributions hybrides (Rangan, Corey \& Cespedes,1993), multiples voies de distributions (Anderson, Day \& Rangan, 1997), Systèmes hybrides de commercialisation (Moriarti \& Moran, 1990), Intégration partielle (Adelman, 1949; Carlton, 1979) ou Combinaisons contractuelles (Bai \& Tao, 2000).

Dans tous les cas décrits sous ces différentes étiquettes, l'idée est la même : la même entreprise (ou société), dans un contexte institutionnel donné, s'appuie simultanément sur différentes modalités d'organisation pour contrôler des transactions similaires ${ }^{1}$ (ou identiques).

\footnotetext{
${ }^{1}$ Pour une discussion plus détaillée sur la similarité des transactions en formes plurielles, voir Krzeminska et al (2014).
} 
Pour illustrer cette idée, considérons par exemple la représentation simplifiée de deux faisceaux de transactions similaires, comme on le voit sur la Figure 1. La ligne pointillée dans A désigne la part de la production qui est intégrée dans la société 2 , tandis que dans $\mathrm{B}$ elle exprime la portion de la distribution qui appartient à la société 1 . Dans les deux cas, une partie de la production/distribution appartient à d'autres agents, auxquels une entreprise est liée soit par l'intermédiaire du marché, soit par différents types de contrats, soit encore à travers la combinaison de multiples modalités d'organisation pour se procurer/distribuer des ‘inputs's/produits similaires ${ }^{2}$.

Figure 1. Représentation schématique de la combinaison des modalités d'organisation dans l'obtention d'inputs (A) et dans la distribution des produits (B).

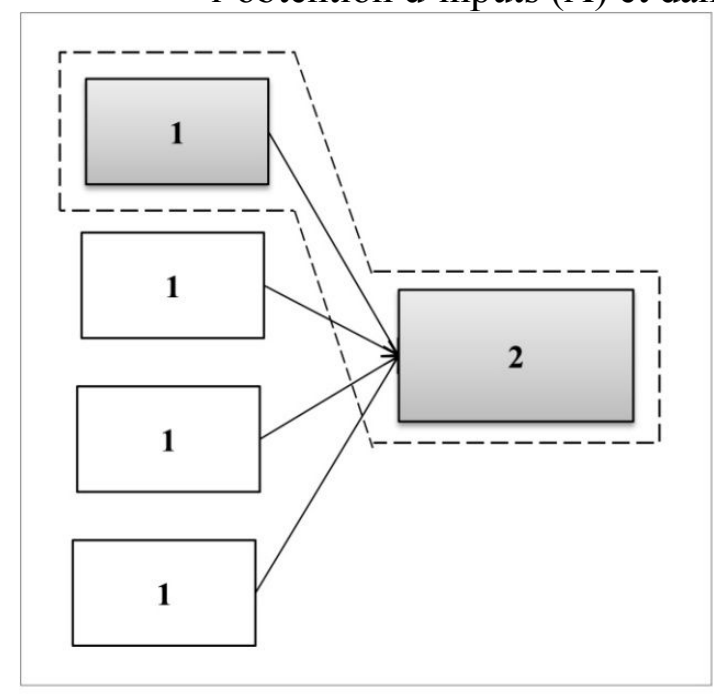

A

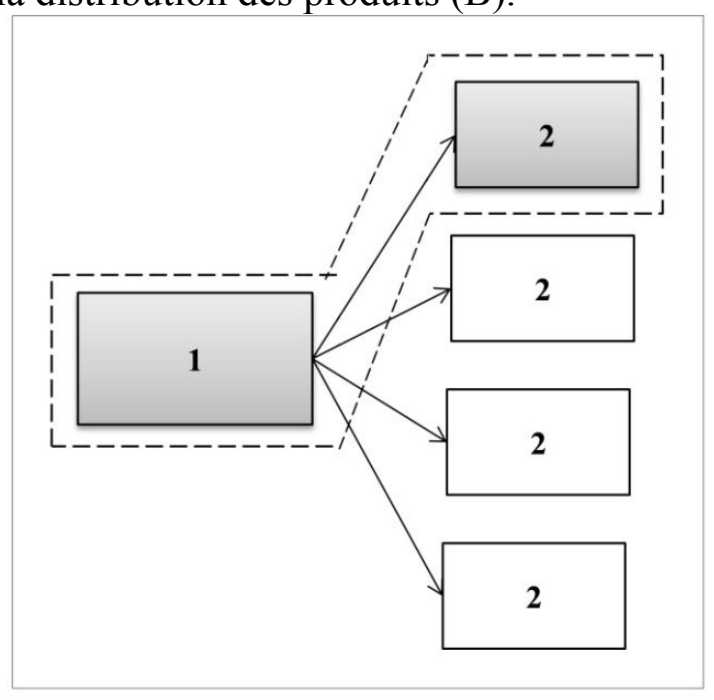

B

Note. Repris de «Le phénomène des formes plurielles » par Schnaider, Raynaud et Saes (2014) in Menard et al (2014).

Ce phénomène a été d'abord constaté dans les années 80 dans le contexte des systèmes de franchise, où on observe que plusieurs (la plupart) franchiseurs s'appuient simultanément sur des unités de sociétés franchisées et sur des unités appartenant à l'entreprise pour distribuer leurs produits (voir entre autres, Azevedo \& Silva, 2007, Lafontaine, 1992, Lafontaine \& Shaw, 2005) $)^{3}$. Et cela reste encore à ce jour l'exemple le plus remarquable du phénomène des formes plurielles, tel qu'illustré dans la Figure 1B).

\footnotetext{
${ }^{2}$ À titre d'illustration, nous avons choisi de mettre l'accent sur la combinaison de "faire-et-acheter" bien que plusieurs autres possibilités puissent exister.

${ }^{3}$ De même et plus récemment, Dutta et al (1995) et Heide (2003) ont fait apparaître l'utilisation simultanée de ventes directes et chaînes de distribution de tiers pour les mêmes produits. Par exemple, le fabricant de jouets LEGO combine les chaînes de distribution de ses tierces parties avec ses propres chaînes de distributions basées
} 
Des combinaisons semblables ont été trouvées plus tard dans divers autres secteurs (en amont et en aval). Par exemple, Parmigiani (2007) et Parmigiani et Mitchell (2009) ont montré que l'approvisionnement de composants métalliques par l'industrie d'outillages est fait en produisant et en achetant (Figure 1A). Au-delà des achats et de la distribution des produits, Nikerson et Silverman (2003) et He et Nickerson (2006) ont aussi montré dans leur analyse l'existence simultanée de plusieurs formes d'approvisionnement des services (Transports routiers dans leur analyse).

Cependant, comme je le démontre dans le chapitre 2, les théories les plus pertinentes, l'Économie des Coûts de Transaction (ECT), la Théorie 'moderne' des Droits de Propriété (PRT) et l'approche dite de 'Resource Based', ont des difficultés à expliquer la simple existence du phénomène, parce qu'elles défendent la supériorité d'une modalité unique d'organisation pour contrôler chaque transaction.

Je démontre aussi que face au défi que représente l'explication théorique de l'existence de formes plurielles, plusieurs explications théoriques différentes ont émergé au cours de la période récente, sans qu'on puisse aboutir à un consensus à ce jour sur les sources de motivation de cette coexistence de modalités organisationnelles diverses. Autrement dit, les motivations poussant vers les formes plurielles d'organisation ne sont pas encore bien comprises, même si elles ont donné lieu à des contributions théoriques intéressantes. C'est pourquoi j'ai choisi d'aborder ce sujet dans cette thèse.

En effet, des études empiriques nombreuses démontrent que la coexistence des modalités d'organisation va au-delà de la simple combinaison des caractéristiques des marchés et des 'hiérarchies' (Veuglers \& Cassiman, 1999, Krzeminska et al, 2014). Comme décrit plus loin dans Menard, Saes, Silva et Raynaud (2014), certaines entreprises réunissent plus de deux modalités d'organisation pour le même ensemble de transactions (par exemple, le marché au comptant, les contrats formels et l'intégration verticale); elles peuvent ainsi réunir simultanément diverses combinaisons et, selon les cas, en proposer des déclinaisons variées (par exemple en combinant différents types de formes hybrides). Ainsi, Delfi, un important acteur dans l'industrie du cacao, obtient $45 \%$ des fèves de cacao avec des contrats

sur internet (Mols, 2000). Et cette coexistence de chaînes de distribution a même été envisagée comme une conception dominante de design de marketing (Moriati \& Moran, 1990). 
relationnels, $50 \%$ avec des contrats formels à long terme et les 5\% restants sont obtenus avec des contrats formels à moyen terme (Menard et al, 2014).

Malgré la variété de ces manifestations et l'importance qu'elles ont au plan empirique, on connaît très peu la raison d'être de l'une ou l'autre de ces diverses combinaisons. En fait, il n'y a à ce jour, à ma connaissance, qu'un seul article traitant des conditions déterminant combien devrait être fait en interne et combien devrait être acheté par le biais de diverses formes, ce qiui est la caractéristique de ces arrangements complexes (Puranam, Gulatti \& Battcharia, 2003); et même dans ce cas de figure, cet article néglige la possibilité que les entreprises aillent au-delà de la simple combinaison du 'faire' et du 'faire-faire' (« make-andbuy ») C'est pourquoi j'ai choisi d'aborder cette question de façon détaillée dans les chapitres 3,4 et 5 de cette thèse.

\section{Définition opérationnelle et transaction en jeu}

La coexistence de diverses modalités d'organisation pour contrôler des transactions similaires (ou identiques) porte des noms différents dans la littérature existante, comme on l'a vu cidessus; dans cette thèse, je vais suivre Bradach et Eccles (1989) et Menard (2013) et identifier ces arrangements comme "formes plurielles". Je fais ce choix parce que ce concept est plus général puisqu'il peut être utilisé pour capter les deux types de transactions où ces combinaisons peuvent intervenir, soit en amont et/ou en aval.

Cependant, Il me faut mentionner d'emblée que dans les contributions empiriques présentées dans cette thèse, je suis seulement intéressée au cas des approvisionnements en 'inputs'. C'est pourquoi dans ma thèse, lorsque je me réfère aux formes plurielles, je fais exclusivement référence á des transactions en amont.

\section{Objectifs et structure de la thèse}

La thèse est composée de quatre (4) chapitres, outre l'introduction et la conclusion. Chaque chapitre est un article, proposant une approche différente mais complémentaire des formes plurielles. La première moitié de la thèse reste théorique, alors que la deuxième partie présente des contributions empiriques qualitatives destinées à donner de la substance au cadre 
théorique préalablement élaboré. Chaque article se concentre sur une seule question de recherche associée aux formes plurielles et est destiné à rester indépendant des autres, ce qui peut expliquer la présence de certains rappels en début de chapitres et, parce que ces chapitres sont fortement complémentaires, la présence de certains chevauchements.. La figure 2, cidessous, résume les relations entre les quatre (4) articles composant cette thèse.

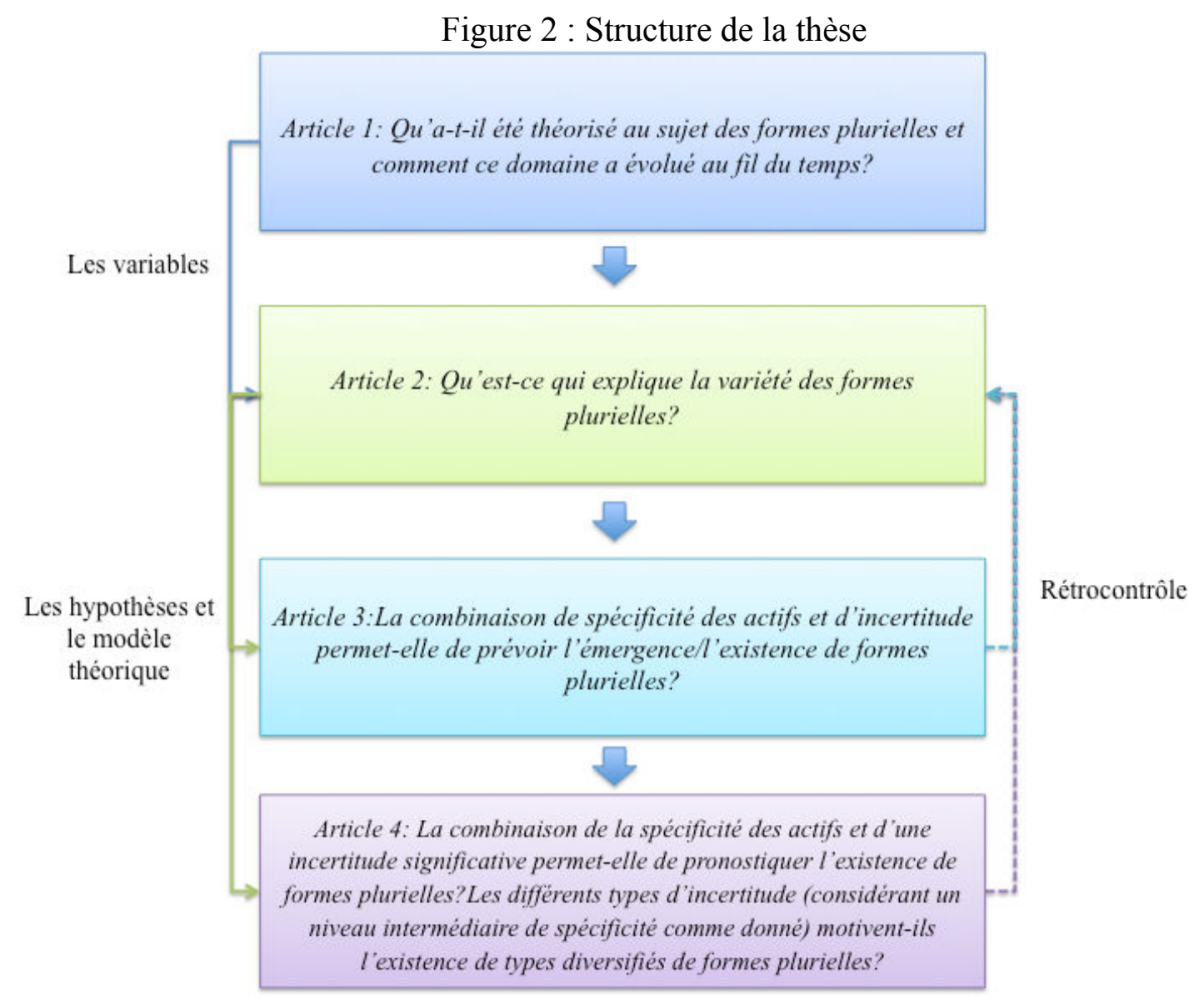

La logique fondamentale sous-jacente à la thèse et que ce schéma tente de capter est que chaque article sert soit comme entrée, soit comme complément au chapitre suivant. C'est ainsi que l'enquête bibliométrique dans l'article 1 alimente le développement du modèle théorique dans l'article 2, en identifiant des variables intéressantes et en faisant aussi apparaître des lacunes potentielles dans la littérature existante. Le second document fournit l'arrière-plan théorique qui soutient les deux articles 3 et 4. En dernier ressort, ces deux contributions empiriques sont ainsi destinées à donner de la substance et à contribuer à 'tester' le modèle théorique, bien que cela ne soit pas fait à l'aide d'un test économétrique, pour des raisons d'échantillon discutées dans la thèse. 
Dans les paragraphes qui suivent, je me propose donc de clarifier brièvement ces relations entre les divers articles.

\subsection{Article 1 - Chapitre 2}

Les principales théories auxquelles nous avons fait référence ci-dessus défendent la supériorité d'une modalité d'organisation par rapport aux alternatives existantes, compte tenu des conditions dans lesquelles a lieu la transaction (ou l'ensemble des transactions). Mais, si un seul mécanisme est le plus efficace, pourquoi deux ou même plusieurs d'entre eux sont-ils simultanément combinés pour organiser des opérations similaires (ou identiques)? C'est cette question qui motive les développements du premier document.

Fondamentalement, cet article entend vérifier ce qui a été théorisé au sujet des formes plurielles et comment ce domaine a évolué au fil du temps. Je m'y préoccupe particulièrement des multiples explications théoriques sur les raisons qui poussent les entreprises à adopter des formes plurielles, question qui à ce jour ne fait l'objet d'aucun consensus entre théoriciens.

C'est pourquoi, dans ce document, j'ai tout d'abord pris appui sur la plateforme scientifique ISI Web of Science afin d'identifier les articles disponibles sur mon thème de recherche, cde qui m'a permis de repérer 182 documents pertinents. J'ai poussé l'analyse plus loin en utilisant des mesures telles que le nombre de publications par an et le nombre de citations par article. Déjà à ce niveau, on voit apparaître des résultats intéressants, qui permettent de localiser les origines des analyses explicites portant sur ces modes d'organisation vers la fin des années 1980 et de faire aussi apparaître l'importante croissance de cette littérature au cours de la dernière décennie. Ainsi, le nombre moyen d'articles publiés chaque année au cours de cette période est de 12.4 versus 4.65 au cours des 20 années précédentes). L'exercice bibliométrique a aussi permis d'identifier les publications les plus pertinentes sur le sujet, i.e. ceux présentant le plus grand nombre de citations au fil du temps. Fait intéressant, un grand nombre d'entre elles ont été publiées après 2000, et la plupart de ces contributions, tant théoriques qu'empiriques, portent sur les systèmes de franchise et le problème dit de 'dualité', c'est-à-dire les explications possibles au fait que les franchiseurs tendent systématiquement à 
combiner le recours aux franchisés 'autonomes' avec la coexistence de magasins possédés en propre.

Dans une perspective plus qualitative, la deuxième partie du document passe en revue quelques contributions sur les formes plurielles qui me sont apparues particulièrement significatives au vu des questions que je me pose. J'ai ainsi organisé ces contributions dans l'ordre chronologique, en vue de comprendre l'évolution des explications de l'existence de formes plurielles. Il apparaît ainsi, comme semblait le suggérer initialement la théorie des coûts de transaction (Williamson, 1985, par exemple), dominante dans le domaine de l'analyse des modes d'organisation, que les formes plurielles ont d'abord été traitées comme un phénomène passager. Il a fallu un certain temps pour qu'elles finissent par être reconnues comme des arrangements stables et pérennes, pour lesquelles il devenait donc impérieux que l'analyse produise des explications convaincantes quant à leur existence et à leurs caractéristiques. La question a aussi gagné en importance dans les programmes de recherche en raison du fait que les études empiriques révélaient de plus en plus la multiplicité des formes plurielles dans des secteurs très variés, et bien au-delà du seul cas de la franchise, en amont comme en aval des transactions. Le schéma 3 ci-dessous résume cette évolution.

Figure 3 - L'évolution des contributions théoriques sur les formes plurielles au fil du temps.

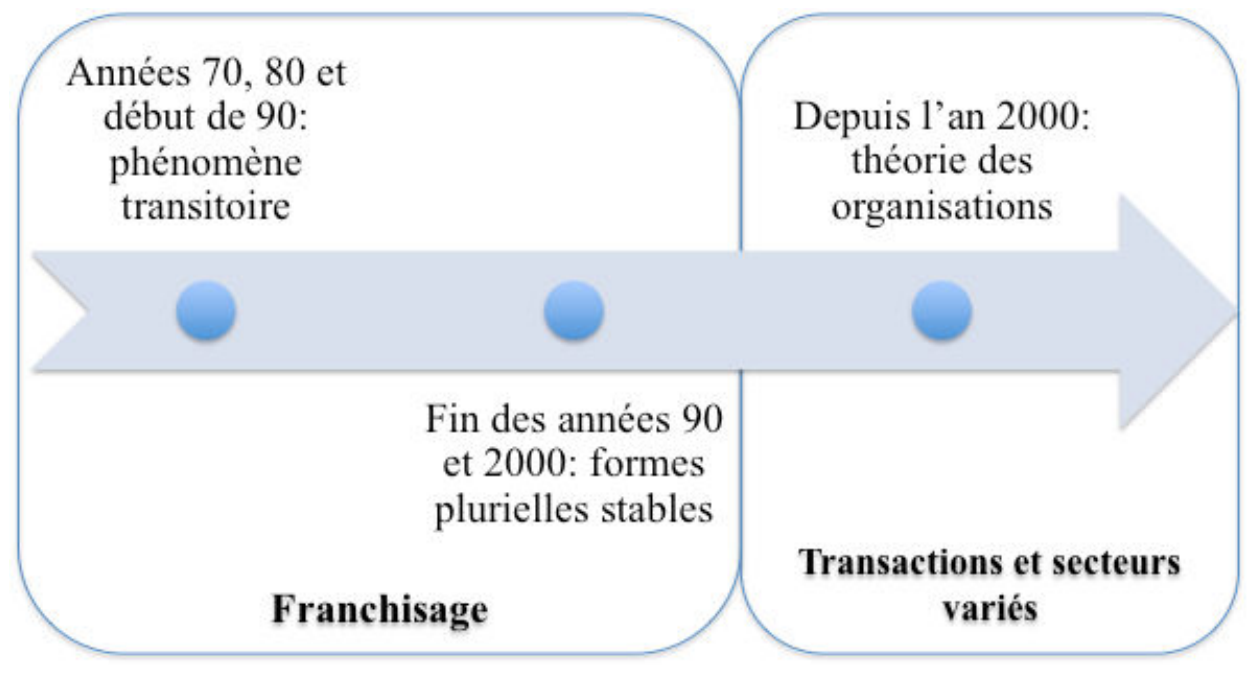

J'ai aussi pu identifier, grâce à l'étude bibliométrique, deux variables qu'on retrouve au cœur des idées exprimées dans ces perspectives théoriques, nonobtant leur diversité, pour expliquer l'existence et la stabilité des formes plurielles: la spécificité des actifs ainsi que les facteurs d'incertitude. Néanmoins, ces variables sont restées très mal explorés, ce qui tendait à 
pointer la nécessité de nouvelles contributions. C'est ce constat qui m'a poussée, dans le document 2 , à construire un modèle théorique original pour essayer de rendre compte de ces déterminants des formes plurielles.

Une autre lacune potentielle que j'ai pu identifier dans la littérature existante et qui incite à de nouvelles recherches l'observation, essentiellement nourrie par de nombreuses contributions empiriques, faisant apparaître la variété de formes plurielles. Sur la base de cette exploration bibliométrique, renforcée par ce que nous avons pu observer dans les études empiriques rassemblées dans Menard et al. (2014), j'ai ainsi été amenée à constater l'absence de contributions visant à rendre compte de façon cohérente, dans une approche théorique intégrative, de cette hétérogénéité des formes plurielles. Ce constat a conforté ma motivation à développer un modèle théorique et à en dériver des hypothèses, ce qui est au cœur du document 2 (chapitre 3).

\subsection{Article 2 - Chapitre 3}

Le second document composant cette thèse est au cœur de mon travail. Non seulement représente-t-il ma contribution théorique originale, mais il alimente aussi les deux prochains chapitres, au contenu nettement empirique.

Je souligne qu'il existe très peu de contributions, dans la littérature spécialisée, concernant la composition des formes plurielles et leurs variétés. Par conséquent, je cherche à faire la lumière sur la variété des manifestations des formes plurielles, c'est-à-dire la diversité des combinaisons de modalités organisationnelles qui les caractérisent. Mon objectif dans cet article est donc d'apporter une réponse à la question suivante: Qu'est-ce qui explique la diversité des formes plurielles?

Bien que le concept de diversité auquel je me réfère comprenne toutes les combinaisons possibles des dispositions organisationnelles qui sont simultanément employées afin d'obtenir un 'entrant' donné, j'ai choisi une approche qui permette de garder l'argumentation théoriquement et empiriquement 'gérable'. J'ai donc regroupé ces combinaisons en trois sousensembles, soit: (1) celles qui impliquent les classes de modes d'organisation classiquement identifiés dans la littérature récente (faire-et-acheter, faire-et-partager, acheter-et-partager, 
faire-acheter-et-partager), que j'identifie par le terme 'between'; (2) celles qui mixent plusieurs catégories de formes hybrides et se situent donc dans cette classe de modes d'organisation (partager-et-partager, sous des formes différentes), d'où le terme de 'within' que j'ai retenu; et (3) enfin celles qui s'appuient sur les deux grands groupes mentionnés cidessus (faire-partager-et-partager, encore là sous des formes de partage différentes, acheterpartager-et-partager, faire-acheter, partager-et-partager, chaque fois dans des formes de partage différentes), que j'appelle 'combi'.

Je dois préciser que pour comprendre les motivations sous-jacentes à cette grande variété de formes plurielles, j'ai dû tout d'abord prendre du recul et construire un modèle théorique pour pronostiquer à quel moment les formes plurielles devraient ou ne devraient pas être mises en œuvre. Pour faire cela, j'ai suivi Williamson (1991), Parmigiani (2007), Krzeminska (2008) et Menard (2013, 2014), ce qui m'a conduit à proposer un modèle intégrant la variable 'actif spécifique' et la variable 'incertitude' (variables qui ont été définies dans le document 1 lors de l'examen des motivations possibles proposées par la littérature existante pour expliquer l'existence des formes plurielles et leur variété.

L'idée fondamentale du modèle est que lorsque le niveau d'incertitude concernant une transaction donnée (ou un ensemble de transactions) est au-dessous d'un certain seuil ( $\mathrm{u}_{1}$ sur la Figure 4), seules les formes non-plurielles seront mises en œuvre, de manière à minimiser les coûts de transaction (Williamson, 1985,1991). En dessous de ce seuil, qui revient à considérer comme neutre l'effet de l'incertitude, on retrouve les formes désormais classiques introduites par Williamson (1991). 
Figure 4. Un modèle intégrateur

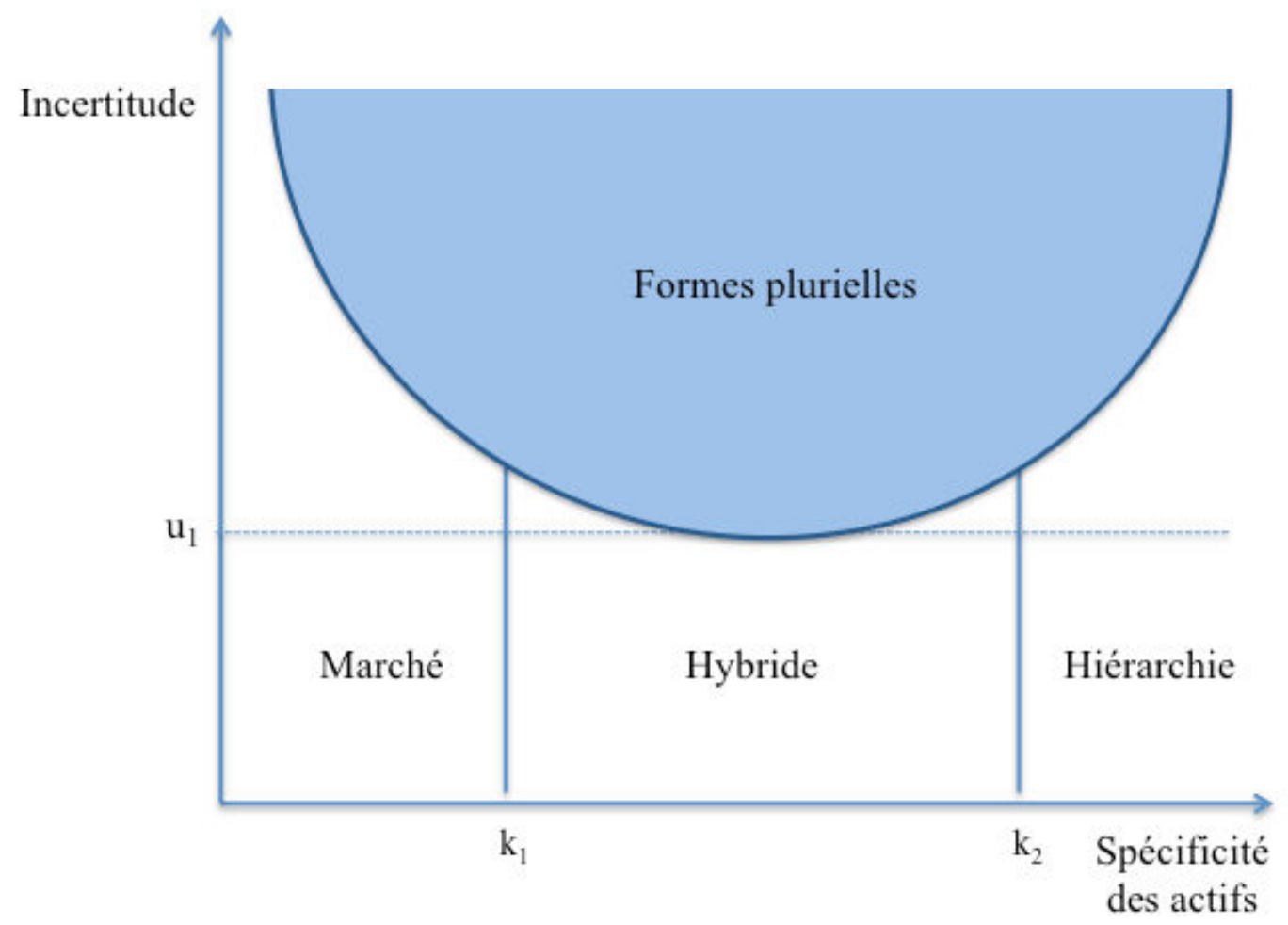

Cependant, quand le niveau d'incertitude concernant une transaction donnée (ou un ensemble de transactions) est supérieur à $\mathrm{u}_{1}$, alors le modèle suggère qu'on peut anticiper la présence de formes plurielles aussi bien que non-plurielles, dans la mesure où on a à la fois des investissements (plus ou moins) spécifiques en même temps que la variable captant l'incertitude concernant la (les) transaction(s) en jeu devient significative.

Considérons, par exemple, une situation où la transaction donnée implique un très bas niveau de spécificité des actifs. Dans ce cas, les parties à la transaction peuvent être trivialement remplacées, même quand il y a des perturbations imprévues. C'est pourquoi le marché au comptant devrait l'emporter, même quand le niveau d'incertitude concernant la (les) transaction(s) en jeu est (sont) très haut(s), bien au-dessus du niveau $\mathrm{u}_{1}$. À l'inverse, quand le niveau spécificité des actifs est très élevé (ou que ces actifs sont fortement dédiés), les parties à la transaction sont irremplaçables et donc, pour économiser sur les mécanismes complexes et coûteux de sauvegarde de la relation transactionnelle face aux risques contractuels, l'intégration verticale (ou hiérarchie) devient la modalité la moins chère possible pour organiser cette opération, sans se soucier du niveau d'incertitude, ce qui rejoint le raisonnement classique de Williamson dans son analyse de l'arbitrage entre 'faire' et 'faire faire'. 
Cependant, entre ces deux cas polaires (entre $\mathrm{k}_{1}$ et $\mathrm{k}_{2}$ ou proche d'eux, du côté gauche ou droit) les deux cas de figure (formes plurielles et formes non plurielles) pourraient se développer. La raison en est simple: au fur et à mesure que le niveau de spécificité des actifs requis croît, remplacer les parties à la transaction devient de plus en plus difficile et instituer des mesures de sauvegarde devient de plus en plus complexe et coûteux.

En général, dans une situation impliquant un bas niveau d'incertitude (en-dessous de $\mathrm{u}_{1}$ ), les entreprises seraient donc incitées à faire appel aux modalités hybrides (Menard, 2004) pour faire face à ces niveaux de spécificité. Ces arrangements 'hybrides' allient en effet les attributs «blancs» sur les marchés avec les «noirs » dans les hiérarchies pour créer une teinte uniforme de «gris» (Lewin- Solomon, 1998). Néanmoins, quand l'incertitude devient élevée (supérieure à $\mathrm{u}_{1}$ ) l'efficacité des arrangements hybrides classiques tend de plus en plus á se détériorer parce qu'ils exigent des réponses coordonnées aux éventualités imprévues (Williamson, 1991). Contrairement à Williamson (1991), je propose donc dans ces cas de considérer que les entreprises ne feront plus appel au marché au comptant (réaction unilatérale) ni à des hiérarchies (puissance de fiat) mais aux formes plurielles. Ce sont des «hybrides d'un genre tout spécial» (Menard et al, 2014), qui ne forment pas une «teinte uniforme de gris », mais combinent plutôt, en les maintenant distincts, des attributs «blancs » avec des attributs « noirs » (Lewin- Solomon, 1998) ou bien les « blancs » avec les « noirs » ou avec les « gris » pour composer la « zone bleue » dans la Figure 4.

L'idée fondamentale que je développe dans ce papier est alors que selon la source d'incertitude, les marchés au comptant ou les hiérarchies sont inadaptés pour faire face à ces dangers (qui correspondent à ce que Williamson a proposé d'appeler les 'contractual hazards').

Par exemple, lorsque l'incertitude prend sa source á l'intérieur de l'entreprise (par exemple, dans la difficulté qu'il y a à mesurer «le travail d'équipe» décrit dans Achian et Demsetz (1972-), la puissance du fiat propre à l'organisation hiérarchique n'est plus suffisante pour garantir l'efficacité dans la mise en œuvre des transactions (Coff,1999). Dans le cas contraire, où les sources de perturbations proviennent du marché, la solution intégrée ne fournit pas toujours la réponse la plus efficace. Pour illustrer cette idée, considérons le cas où la qualité 
de certains investissements spécifiques donnés ne peut pas être facilement évaluée. Ceci peut potentiellement ouvrir la voie à des comportements opportunistes, au lieu de promouvoir des réponses efficaces.

C'est pourquoi, je propose que les entreprises peuvent mieux gérer l'incertitude lorsque celleci est élevée et que les investissements spécifiques sont á un niveau intermédiaire, en activant les formes plurielles; autrement dit, en combinant les gains complémentaires que peut assurer le recours simultanément à des modalités alternatives d'organisation.

En poussant l'analyse plus loin, c'est-à-dire au-delà de la prévision du recours à des formes plurielles ou non-plurielles, le modèle proposé permet de capter l'idée qu'il y a beaucoup d'hétérogénéité dans la «zone bleue» (schéma 4). Par exemple, les formes plurielles du type «faire-et-acheter », que typiquement on trouve dans les chaînes de franchise où les entreprises combinent leurs propres magasins avec les unités franchisées qui sont contractées pour cela, sont substantiellement différentes de la manière dont Minerva, une entreprise leader au Brésil dans le secteur de bœuf, se procure les 'inputs' de bovins: $65 \%$ proviennent de contrats relationnels, $25 \%$ de contrats formels à court terme et le reste $(10 \%)$ provient de contrats formels à long terme (Menard, Saes, Silva et Raynaud, 2014).

Pour pouvoir explorer de manière plus rigoureuse cette variété de formes plurielles, je les ai groupés en 3 (trois) catégories et j'ai construit des hypothèses concernant les différents types d'incertitude (ou, plus exactement, les différentes sources d'incertitude captant les principales dimensions du concept: incertitude de marché, incertitude technologique, et incertitude de performance), et cela pour chacun des 3 types de formes plurielles («Between» ou faire-etacheter ou acheter-et-acheter; «within» ou partager-et-partager, avec des formes de partage différentes; et «Combo» ou la combinaison des deux types précédents). Le tableau 1 résume ces hypothèses (pour plus de détails, voir le chapitre 3 ). 
Tableau 1. Hypothèses

\begin{tabular}{ccc}
\hline Type d'incertitude & $\begin{array}{c}\text { Type prévu de formes } \\
\text { plurielles }\end{array}$ & Hypothèses \\
\hline Marché & Between & $\mathrm{H}_{1 \mathrm{a}}$ \\
Technologique & Between & $\mathrm{H}_{1 \mathrm{~b}}$ \\
$\begin{array}{c}\text { Évaluation de } \\
\text { performance }\end{array}$ & $\begin{array}{c}\text { Between ou Within, dépendant } \\
\text { du niveau de spécificité des } \\
\text { actifs }\end{array}$ & $\mathrm{H}_{1 \mathrm{c}}, \mathrm{H}_{1 \mathrm{~d}}$ \\
$\begin{array}{c}\text { Marché et technologique } \\
\begin{array}{c}\text { Marché ou technologique } \\
\text { et évaluation de } \\
\text { performance }\end{array}\end{array}$ & $\begin{array}{c}\text { Between ou Combo, selon ce } \\
\text { qui est combiné }\end{array}$ & $\mathrm{H}_{1 \mathrm{e}}, \mathrm{H}_{1 \mathrm{f}}$ \\
\hline
\end{tabular}

La conception sous-jacente à ces hypothèses est que différents types d'incertitude, sous réserve d'un certain niveau de spécificité des actifs, motivent la diversité de formes plurielles.

Ces hypothèses, développées en détail dans le chapitre 3, prévoient les circonstances dans lesquelles chaque type de formes plurielles devrait émerger et être efficace; c'est pourquoi, elles devraient permettre d'éclairer (y compris pour les décideurs) quelle combinaison de modes d'organisation convient le mieux aux conditions dans lesquelles ces arrangements opèrent. Cela pourrait aider à expliquer pourquoi certaines transactions sont réalisées à l'aide d'une combinaison ou d'une autre, et même à clarifier pourquoi différentes entreprises, opérant dans le même secteur et dans un même environnement institutionnel, utilisent différentes combinaisons de modes d'organisation pour contrôler leurs transactions.

Bien que je demeure strictement théorique dans ce document, je confronte par la suite mon modèle et les hypothèses ainsi construites à des données empiriques dans les deux prochains documents. Comme je le soulignerai dans ce qui suit (et dans les chapitres détaillés de la thèse), ces deux papiers (correspondant aux chapitres 4 et 5) fournissent des points de vue complémentaires, et un support aux idées fondant le modèle Dans le troisième document, j'étaye cela à partir d'un un cas d'étude clinique «embedded», suivant les protocoles proposés par des travaux récents (Yin, 2003; Baker \& Gil, 2013). Dans le quatrième document, je propose une approche alternative, reposant sur une enquête qualitative auprès de 24 entreprises brésiliennes opérant dans le secteur agro-alimentaire. 


\subsection{Article 3 - Chapitre 4}

Dans ce chapitre, je propose une première confrontation du modèle théorique développé dans le document 2, associant la spécificité des actifs et l'incertitude aux formes plurielles et nonplurielles, à une étude empirique reposant sur une étude de cas approfondie. L'objectif est alors d'apporter une réponse à la question suivante: la combinaison de spécificité des actifs et d'incertitude permet-elle de prévoir l'émergencell'existence de formes plurielles?

Cette analyse m'a aussi permis d'aller plus loin dans mon modèle et de vérifier si oui ou non la combinaison de différents niveaux d'incertitude et de spécificité des actifs détermine le choix de modalités distinctes d'organisation. Autrement dit, je me suis non seulement intéressée à l'examen des formes organisationnelles selon qu'elles se situent à l'intérieur ou à l'extérieur de la région des formes plurielles (la zone bleue), définie dans mon modèle (voir document 2), mais j'ai aussi cherché à évaluer comment ces différentes transactions, portant sur l'achat de produits impliquant différents niveaux de spécificité et d'incertitude, peuvent être réparties dans la configuration dessinée par mon modèle.

Avec cet objectif en ligne de mire, j'ai effectué une étude approfondie d'un cas clinique «embedded» ( Yin, 2003; Baker \& Gil, 2003), le cas de l'entreprise Korin. Ce choix a été motivé par le fait que cette entreprise se procure un certain nombre de produits simultanément par le biais de formes non-plurielles et de formes plurielles. L'étude approfindie de ce cas permet alors d'éclairer pourquoi l'entreprise Korin adopte les formes plurielles pour s'approvisionner en certains produits mais à recours à des formes non- plurielles pour d'autres. En outre, en analysant plus attentivement les produits concernés, je peux examiner et comparer comment ils se distribuent par rapport aux variables retenues (spécificité des actifs et incertitude) et donc dans le cadre de la figure 4.

Cette analyse conduit à identifier des combinaisons de variables qui viennent à l'appui de mon modèle, comme l'illustre la Figure 5. D'abord, les transactions dans la «zone bleue» sont organisées en formes plurielles (maïs conventionnel et bio ; œufs sans antibiotiques) et celles qui sont hors de la «zone bleue » sont organisées en formes non-plurielles (soja ordinaire ; volaille). Ces résultats fournissent un support à l'idée que la combinaison de la variable spécificité avec la variable incertitude peut permettre prévoir l'existence des formes plurielles 
et non-plurielles, dépendant de l'importance que la combinaison de ces deux variables prend dans la transaction (ou l'ensemble des transactions) en jeu.

Figure 5. Une illustration empirique du modèle intégrateur

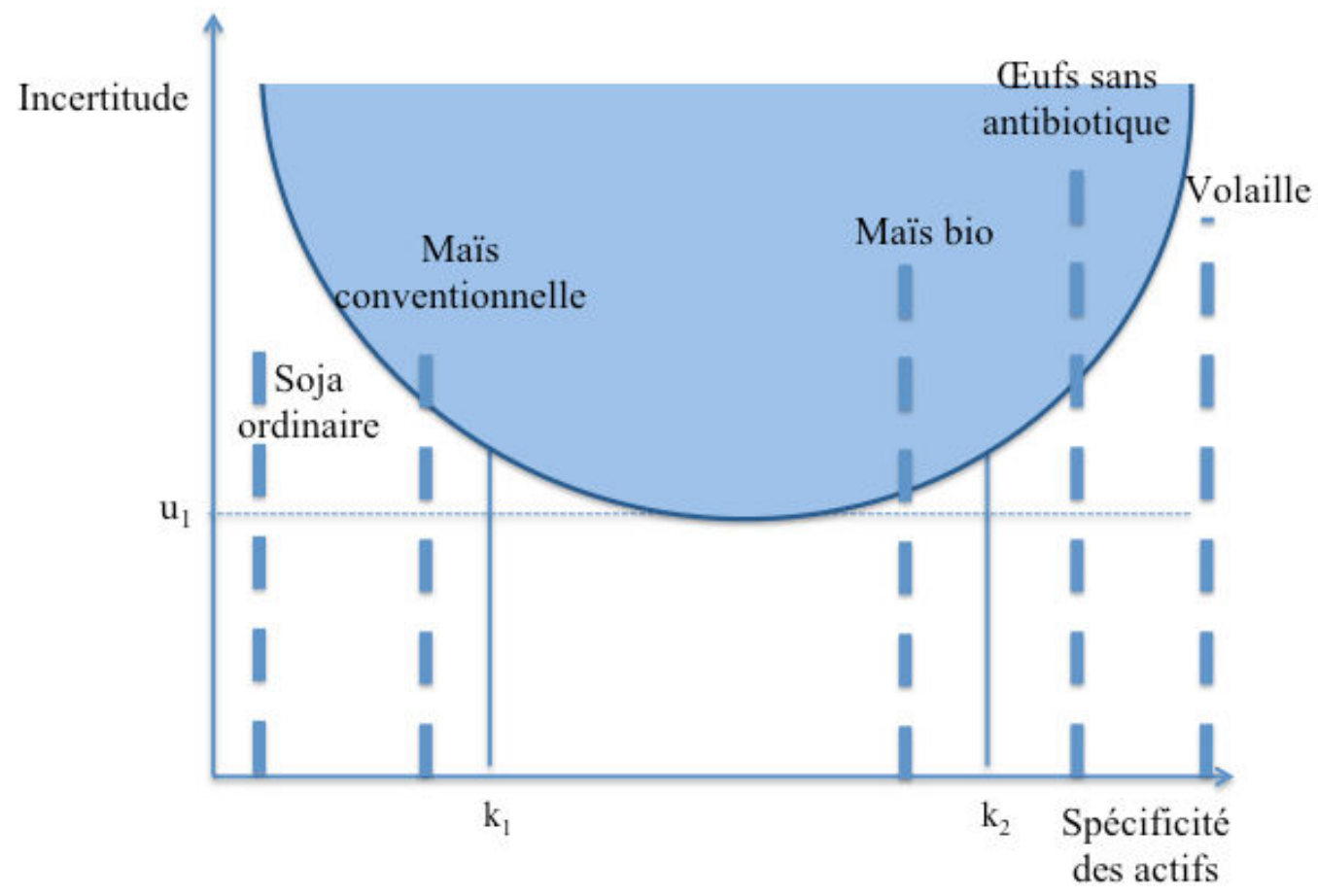

Deuxièmement, si on tente d'étendre le raisonnement au-delà de ce que circonscrit la «zone bleue», on retrouve aussi l'idée qu'en fonction des différents niveaux d'incertitude et des différentes intensités de spécificité des actifs, les transactions sont différemment réparties dans le modèle. L'analyse permet en effet de positionner les transactions concernant différents 'inputs' selon les différentes modes d'organisation. Par exemple, bien que le soja ordinaire et la volaille tombent en dehors de la «zone bleue», ils sont obtenus par l'intermédiaire de modalités très différentes: alors que le soja ordinaire est acquis par le biais des contrats uniformes de long terme, la volaille est produite de manière intégrée (« in-house »). Si ion se restreint aux seuls produits qui tombent dans la «zone bleue», on remarque alors que chacun d'entre eux est acquis par le biais d'une combinaison spécifique de modes d'organisation: le maïs conventionnel est obtenu par le biais de différents types de contrats relationnels, le maïs bio et les œufs sont obtenus dans la cadre d'une solution où on trouve à la fois une production interne, intégrée, et différents types de contrats formels, le tout dans des proportions variables. 
Il s'agit là de résultats intéressants et inédits, qui confortent le modèle et les hypothèses développées dans l'article 2, nonobstant la nature qualitative et exploratoire des données ici utilisées. Je suis en effet consciente des limites de cette étude de cas clinique «embedded» lorsqu'on entend passer à une généralisation. Certes les résultats, conformes à nos prédictions, tiennent bien la route en ce qui concerne l'entreprise Korin. Mais en va-t-il de même lorsqu'on passe à d'autres entreprises ayant recours aux formes plurielles ?

\subsection{Article 4 - Chapitre 5}

Dans le dernier document de ma thèse, je cherche à confronter le modèle et les hypothèses développées dans le document 2, cette fois à des données concernant un ensemble relativement élevé d'entreprises (24), compte tenu de la difficulté à recueillir ce type de données. J'ai recours à ces données pour essayer de répondre aux questions suivantes: $\boldsymbol{i}-\boldsymbol{L} \boldsymbol{a}$ combinaison de la spécificité des actifs et d'une incertitude significative permet-elle de pronostiquer l'existence de formes plurielles? Et ii - Les différents types d'incertitude (considérant un niveau intermédiaire de spécificité comme donné) motivent-ils l'existence de types diversifiés de formes plurielles?

Dans ce but, j'ai fait une enquête sur l'approvisionnement en 'inputs' auprès de 24 entreprises opérant dans le secteur du marché agricole brésilien et procédant à l'acquisition de 11 inputs différents par le recours à des formes tant plurielles que non-plurielles. Pour évaluer les perceptions des responsables concernant les multiples types d'incertitude (évaluation des marchés, incertitude concernant les performances, incertitude technologique) et le degré de spécificité des actifs, j'ai fait usage d'un questionnaire basé sur une échelle de Likert de 4 points. Dans la perspective de cet article-ci, j'ai sélectionné les questions apparaissant dans le tableau 2, ci-dessous. 
Tableau 1. Questions, variables et indicateurs

\begin{tabular}{ccc}
\hline Questions & Variables & Indicateurs pour \\
\hline $\begin{array}{c}\text { La demande de mes 'inputs' est très } \\
\text { imprévisible }\end{array}$ & $\begin{array}{c}\text { Volatilité de la } \\
\text { demande }\end{array}$ & \\
$\begin{array}{c}\text { L'approvisionnent de mes 'inputs' } \\
\text { varie beaucoup au cours de la } \\
\text { récolte (questions climatiques, une } \\
\text { seule récolte, pas de stock, etc.) }\end{array}$ & Volatilité de l'offre & \\
\hline
\end{tabular}

Il est difficile de mesurer la qualité de mes 'inputs'

Coûts de mesure

Mes 'inputs' sont certifiées donc je n'ai pas de problèmes pour mesurer la qualité offerte par mes fournisseurs

La qualité de mes 'i nputs' varie de manière significative

\section{Coûts de mesure} (mesure inversée: plus la valeur est élevée, moindre sont les coûts de mesure)

Coûts de mesure/contrôle
Incertitude d'évaluation de performance
Il existe plusieurs façons de produire mes 'inputs'

Il est difficile de déterminer la meilleure technologie pour produire mes 'inputs'
Variété technologique

Variété technologique/

Incertitude technologique
Afin de contrôler la qualité de mes 'inputs', je dois compter sur un personnel spécialisé

La qualité de mes inputs est affectée

par des contraintes de temps

Mes fournisseurs peuvent commercialiser leur production de diverses façons parce qu'ils ont beaucoup d'acheteurs

La qualité est ma principale préoccupation par rapport à mes inputs
Spécificité des actifs humains

Spécificité des actifs temporelles

Quasi-rentes (mesure inversée: plus Spécificité des actifs la valeur est élevée, plus petite est la quasirente)

Spécificité de l'actif général 
J'utilise les données ainsi recueillies pour effectuer un ensemble d'analyses exploratoires, essentiellement qualitatives et comparatives, en m'appuyant principalement sur des statistiques descriptives. En effet, les limites de mon échantillon ne me permettent pas d'effectuer des analyses quantitatives plus sophistiquées. Cependant, dans la mesure où mon étude est la première à ma connaissance à évaluer de façon aussi fine les choix organisationnels prenant en compte les formes plurielles et à le faire à partir d'un modèle relativement général, l'ensemble de ces analyses qualitatives me paraît constituer en soi une contribution importante.

Dans l'article ici résumé, j'ai classé mes résultats de deux (2) façons. D'abord, j'obtiens une vue d'ensemble des valeurs moyennes pour chaque question, tenant compte de l'échantillon en entier, ainsi que le résume le tableau 3 ci-dessous. On peut alors noter qu'en moyenne toutes les variables ont présenté des valeurs faibles ou intermédiaires, malgré de grands écarts. Cela signifie que l'échantillon est diversifié et hétérogène, me permettant donc d'analyser potentiellement les formes plurielles et non-plurielles. 
Tableau 2. Quelques statistiques descriptives considérant l'échantillon en entier.

\begin{tabular}{|c|c|c|c|}
\hline Variables & Questions & Moyenne & Écart-type \\
\hline \multirow[b]{2}{*}{$\begin{array}{l}\text { Incertitude de } \\
\text { marché }\end{array}$} & $\begin{array}{l}\text { La demande de mes 'inputs' est } \\
\text { très imprévisible }\end{array}$ & 1.88 & 0.85 \\
\hline & $\begin{array}{l}\text { L'approvisionnent de mes 'inputs' } \\
\text { varie beaucoup au cours de la } \\
\text { récolte (questions climatiques, une } \\
\text { seule récolte, pas de stock, etc.) }\end{array}$ & 2.75 & 0.94 \\
\hline \multirow{4}{*}{$\begin{array}{l}\text { Incertitude } \\
\text { d'évaluation } \\
\text { de } \\
\text { performance }\end{array}$} & $\begin{array}{l}\text { Il est difficile de mesurer la qualité } \\
\text { des mes 'inputs' }\end{array}$ & 1.50 & 0.78 \\
\hline & $\begin{array}{l}\text { Mes inputs' sont certifiés } \\
\text { donc je n'ai pas de problème } \\
\text { avec la mesure de la qualité } \\
\text { offerte par mes fournisseurs }\end{array}$ & 1.96 & 1.04 \\
\hline & $\begin{array}{l}\text { La qualité de mes 'inputs' } \\
\text { varie de manière significative }\end{array}$ & 2.29 & 1.20 \\
\hline & $\begin{array}{l}\text { Il est difficile de mesurer la qualité } \\
\text { des mes 'inputs }\end{array}$ & 2.88 & 1.08 \\
\hline \multirow[b]{2}{*}{$\begin{array}{l}\text { Incertitude } \\
\text { technologique }\end{array}$} & $\begin{array}{l}\text { Il existe plusieurs façons } \\
\text { de produire mes 'inputs' }\end{array}$ & 2.83 & 1.09 \\
\hline & $\begin{array}{l}\text { Il est difficile de déterminer } \\
\text { la meilleure technologie pour } \\
\text { produire mes 'inputs' }\end{array}$ & 1.96 & 0.86 \\
\hline \multirow{4}{*}{$\begin{array}{l}\text { Spécificité } \\
\text { des actifs }\end{array}$} & $\begin{array}{l}\text { Afin de contrôler la qualité } \\
\text { de mes 'inputs', je dois compter } \\
\text { sur un personnel spécialisé }\end{array}$ & 3.29 & 0.81 \\
\hline & $\begin{array}{c}\text { La qualité de mes 'inputs' est } \\
\text { affectée par des contraintes } \\
\text { de temps }\end{array}$ & 3.00 & 1.10 \\
\hline & $\begin{array}{l}\text { Mes fournisseurs peuvent } \\
\text { commercialiser leur production de } \\
\text { diverses façons parce qu'ils ont } \\
\text { beaucoup d'acheteurs }\end{array}$ & 2.88 & 1.03 \\
\hline & $\begin{array}{l}\text { La qualité est ma principale } \\
\text { préoccupation par rapport à mes } \\
\text { inputs }\end{array}$ & 3.33 & 0.87 \\
\hline
\end{tabular}

Dans une deuxième étape, j'ai groupé les réponses en quatre groupes représentant les variables auxquelles je m'intéresse: évaluation des incertitudes de marché, incertitude sur les performances, incertitude technologique, et spécificité des actifs. J'ai aussi groupé les répondants à cette enquête en trois groupes, en fonction de leur méthode d'approvisionnement 
telle qu'elle apparaît dans la même enquête, à savoir: les formes plurielles «between», les formes plurielles «combo», et les formes non-plurielles. On notera l'absence de formes plurielles « within »; en effet, celles-ci n'ont pu être observées dans notre échantillon.

Tableau 3. Résumé des résultats compte tenu du regroupement indiqué ci-dessus

\begin{tabular}{|c|c|c|c|c|c|c|c|}
\hline \multirow[b]{2}{*}{ Societé } & \multicolumn{5}{|c|}{ Incertitude } & \multirow[b]{2}{*}{$\begin{array}{l}\text { Spécificité } \\
\text { des actifs }\end{array}$} & \multirow[b]{2}{*}{ Gouvernance } \\
\hline & Marché & Performance & Technologique & Ensemble & $\begin{array}{l}\text { Moyenne } \\
\text { par } \\
\text { groupe } \\
\text { sauf les } \\
\text { points } \\
\text { aberrants }\end{array}$ & & \\
\hline Adecoagro & 3.50 & 2.00 & 3.00 & 8.50 & \multirow{9}{*}{7.39} & 3.75 & \multirow{9}{*}{$\begin{array}{c}\text { Formes } \\
\text { plurielles } \\
\text { «between » }\end{array}$} \\
\hline Miolo & 3.50 & 1.75 & 2.00 & 7.25 & & 3.75 & \\
\hline $\begin{array}{l}\text { Imbaúba } \\
\text { Laticínios }\end{array}$ & 3.00 & 2.50 & 3.00 & 8.50 & & 3.00 & \\
\hline $\begin{array}{c}\text { Café } \\
\text { Itamaraty }\end{array}$ & 2.00 & 1.75 & 2.50 & 6.25 & & 2.75 & \\
\hline Café Atalaia & 1.00 & 3.25 & 2.50 & 6.75 & & 3.25 & \\
\hline $\begin{array}{l}\text { Calçados } \\
\text { Doctor Pé }\end{array}$ & 2.00 & 2.25 & 2.50 & 6.75 & & 3.00 & \\
\hline Vibor & 1.50 & 1.75 & 1.00 & 4.25 & & 2.25 & \\
\hline Korin & 3.00 & 2.25 & 2.50 & 7.75 & & 3.00 & \\
\hline Moyenne & 2.44 & 2.19 & 2.38 & 7.00 & & 3.09 & \\
\hline Bertin Ltda. & 3.50 & 3.00 & 1.50 & 8.00 & \multirow{7}{*}{8.15} & 2.25 & \multirow{7}{*}{$\begin{array}{c}\text { Formes } \\
\text { plurielles } \\
\text { « combo » }\end{array}$} \\
\hline São Manoel & 2.50 & 2.25 & 3.00 & 7.75 & & 3.00 & \\
\hline Minerva & 2.50 & 3.25 & 3.00 & 8.75 & & 2.50 & \\
\hline Klabin & 2.00 & 2.25 & 1.00 & 5.25 & & 2.50 & \\
\hline Porto Alegre & 2.50 & 1.75 & 4.00 & 8.25 & & 3.25 & \\
\hline Cultivar & 2.50 & 2.50 & 3.00 & 8.00 & & 3.25 & \\
\hline Moyenne & 2.58 & 2.50 & 2.58 & 7.67 & & 2.86 & \\
\hline Pirassununga & 1.50 & 3.75 & 2.50 & 7.75 & \multirow{10}{*}{6.28} & 4.00 & \multirow{10}{*}{$\begin{array}{c}\text { Formes non- } \\
\text { plurielles }\end{array}$} \\
\hline ViniBrasil & 1.00 & 1.25 & 3.00 & 5.25 & & 4.00 & \\
\hline Don Laurindo & 2.50 & 1.75 & 2.50 & 6.75 & & 3.25 & \\
\hline Astro Café & 2.00 & 2.25 & 3.00 & 7.25 & & 3.00 & \\
\hline Indeca & 2.00 & 2.75 & 2.50 & 7.25 & & 2.50 & \\
\hline $\begin{array}{l}\text { Carmen } \\
\text { Steffens }\end{array}$ & 3.00 & 2.50 & 2.00 & 7.50 & & 2.75 & \\
\hline Amazonas & 2.50 & 1.75 & 2.00 & 6.25 & & 2.75 & \\
\hline Orsa & 1.50 & 1.00 & 1.00 & 3.50 & & 1.25 & \\
\hline Angelelli & 1.50 & 2.50 & 2.50 & 6.50 & & 2.25 & \\
\hline Moyenne & 1.94 & 2.17 & 2.33 & 6.44 & & 2.72 & \\
\hline
\end{tabular}

A partie de ces données, on remarque que la spécificité des actifs est, en moyenne, à un niveau intermédiaire dans les trois groupes (dans mon modèle, il s'agit des valeurs situées entre $k_{1}$ et $k_{2}$ ou proche de ces valeurs, sur la gauche ou la droite). Toutefois, ce degré de spécificité est beaucoup plus homogène dans le cas du groupe de formes plurielles que dans le cas du groupe de formes non-plurielles. Cette observation tend à fournir une solide confirmation à l'hypothèse, maintenant classique en théorie des organisations, à l'effet que 
les formes non-plurielles prévalent dans les situations 'polarisées' où la spécificité des actifs est trop basse ou trop élevée.

Deuxièmement, les formes plurielles apparaissent associées dans l'ensemble à des niveaux plus élevés d'incertitude que les formes non-plurielles. Cette observation conforte l'hypothèse que le recours aux formes plurielles est fortement motivée par des niveaux d'incertitude élevé, et ce en présence de niveaux intermédiaires de spécificité. Néanmoins, ces résultats font aussi apparaître qu'en général, le niveau d'incertitude requis pour motiver ce recours aux formes plurielles est moins élevé que ne le suggérait mon modèle, et se situe plutôt dans une zone intermédiaire. Ceci pourrait indiquer que le seuil attendu d'incertitude nécessaire pour motiver le recours à des formes plurielles ( $\mathrm{u}_{1}$ dans mon modèle) n'est pas aussi élevé qu'on aurait pu le penser. En somme, il semble y avoir une possibilité non négligeable que la seule perception de dangers potentiels liés à des situations incertaines soit suffisante pour pousser à choisir davantage de complexes dans les modes d'organisation. On notera cependant que ce changement de seuil, par rapport à mes attentes initiales, n'invalide pas mon modèle.

Un troisième résultat important établi dans cet article est que la perception du 'monde réel' par les répondants est celle d'un monde complexe, de sorte que toutes les entreprises de mon échantillon se sentent concernées par les trois types d'incertitude. Ceci revient à dire que chaque type d'incertitude, fournit à lui seul un modèle stylisé pour comprendre et appréhender cette complexité. Bien que les données recueillies ne permettent pas d'observer directement cette relation, on en trouve des indications, par exemple dans le fait que l'incertitude affectant les marchés semble pousser vers des formes plurielles de type «between». En effet, si on considère le type «between» comme regroupant des formes plurielles et non-plurielles, comme j'en ai fait l'hypothèse, on observe que les incertitudes affectant les marchés présente un écart par rapport à la moyenne nettement plus élevé. . Par ailleurs, les observations recueillies, et résumées dans le tableau ci-dessus, tendent aussi à faire apparaître que la combinaison deux-à-deux des types d'incertitude tend à conduire à un évitement des formes plurielles de type « between

Enfin, en raison des niveaux élevés de chaque type d'incertitude qu'on observe dans le groupe des formes plurielles de type «combo», j'ai été amenée dans cet article à introduire une proposition supplémentaire, à savoir que cette combinaison des trois types d'incertitude 
pousserait vers le type de formes plurielles «combo», dans un contexte où la valeur de la spécificité des actifs reste intermédiaire.

En dépit des limitations de ces résultats en raison de la taille réduite de l'échantillon et des contraintes que cela m'a imposées en ce qui concerne l'utilisation des méthodes analytiques, on trouve donc dans ces observations de fortes concordances à l'appui de mon modèle et des hypothèses que j'en ai dérivées. Par ailleurs, ces résultats sont évidemment plus 'généralisables' que ceux figurant dans le document 3 dans la mesure où ils couvrent malgré tout un nombre non négligeable d'entreprises réparties sur un nombre élevé de secteurs à l'intérieur de la sphère agro-alimentaire.

\section{Conclusion}

Dans cette thèse j'ai traité un thème qui représente un défi pour l'approche traditionnelle en économie des organisations, celui du recours persistant par les entrepreneurs à des formes plurielles d'organisation. J'ai démontré, à travers l'enquête bibliométrique du premier chapitre, comment le domaine s'est développé au fil du temps, et je l'ai fait en me concentrant sur les multiples explications théoriques qui ont été fournies pour rendre compte de l'existence de ces formes plurielles. J'en ai conclus dans ce chapitre que la combinaison de deux variables, l'une faisant appel à la spécificité des actifs, l'autre à divers types d'incertitude, est à la base de la plupart des explications données. Dans le même temps, cette exploration bibliométrique exhaustive a aussi fait apparaître l'absence de travaux portant sur l'hétérogénéité des formes plurielles, malgré l'existence d'observations empiriques faisant apparaître cette hétérogénéité.

Sur la base de ces résultats, j'ai construit c que je considère comme deux contributions théoriques personnelles et novatrices : (1) la construction d'un modèle théorique intégrant la spécificité des actifs et l'incertitude pour prévoir les conditions d'émergence des formes plurielles et non-plurielles; et (2) la construction d'hypothèses basées sur ce modèle et visant à rendre compte de l'hétérogénéité des formes plurielles. Ce modèle et ces hypothèses ont été développés dans mon chapitre 2. 
Les contributions empiriques des chapitres 3 et 4 fournissent des observations riches et qui tendent à conforter la pertinence de mon modèle et de mes hypothèses ; elles ont aussi permis de faire apparaître des éléments non prévus qui devraient être incorporées dans mon cadre théorique. D'abord, j'ai trouvé dans les observations établies dans les chapitres 3 et 4 des éléments de preuve en faveur de ma courbe en « $U$ » associant la spécificité des actifs avec l'incertitude pour prévoir les formes plurielles. Cependant, les résultats que j'ai obtenu dans le chapitre 4 suggèrent que le seuil d'incertitude $\left(\mathrm{u}_{1}\right)$ indiqué dans mon modèle n'est en réalité pas aussi élevé que prévu, mais plutôt proche d'un niveau intermédiaire. Cela n'invalide pas le modèle, dans la mesure où il est possible d'ajuster la valeur $\left(\mathrm{u}_{1}\right)$ en modifiant légèrement l'échelle (ce qui revient à déplacer la courbe vers le bas). Mais ce résultat entraîne quand même de fortes implications au niveau de l'interprétation : il signifie en effet que des niveaux intermédiaires d'incertitude suffisent pour pousser vers le choix de dispositions organisationnelles plus complexes, et ce malgré les coûts de transaction plus élevés qui peuvent en résulter, du fait que les entreprises souhaitent avant tout se prémunir des conséquences qu'entraînent des situations incertaines. Il y a donc une forte prime à la variable incertitude dans le choix des formes organisationnelles plurielles.

J'ai aussi trouvé dans les observations recueillies dans ces deux chapitres 3 et 4, des éléments concordants soutenant mon hypothèse que les transactions concernées par différents niveaux de spécificité des actifs et d'incertitude sont réparties distinctement en fonction de ces niveaux, et doivent donc être organisées en modes d'organisation distincts, comme l'a suggéré la figure 5 .

Ces deux résultats, combinés, fournissent un fort élément de preuve empirique en faveur de mon modèle théorique. Néanmoins, je suis consciente de ce que les analyses fournies dans les chapitres 3 et 4 restent essentiellement basées sur des éléments de nature qualitative, reposant sur un échantillon limité. De ce point de vue, les possibilités de généralisation restent limitées, de même que le recours à des méthodes quantitatives plus sophistiquées. C'est pourquoi des contributions empiriques supplémentaires, surtout du type quantitatif, sont requises pour conclure avec plus d'assurance que le modèle tient la route empiriquement. Néanmoins, les résultats présentés dans ces deux chapitres sont à ma connaissance les premiers à proposer une explication cohérente, basée sur un modèle, à l'existence et à la diversité des formes organisationnelles plurielles. 
En effet, les observations recueillies fournissent des éléments concordants à l'appui de quelques unes de mes hypothèses. Bien que seul le chapitre 4 les traite explicitement au plan empirique, un examen attentif de mes résultats du chapitre 3 fournit aussi des arguments favorables au modèle. Par exemple, l'idée que les combinaisons des types d'incertitude que j'ai identifiés poussent, selon les cas, vers le type «between » des formes plurielles ou vers le type «combo » (mais jamais vers le type «within»- $\mathrm{H}_{1 \mathrm{e}}, \mathrm{H}_{1 \mathrm{f}}, \mathrm{H}_{1 \mathrm{~g}}, \mathrm{H}_{1 \mathrm{~h}} \mathrm{H}_{1 \mathrm{i}}$ ) a été explicitement vérifiée et confirmée dans le chapitre 4 , mais était déjà présente et conforté par les éléments de l'étude de cas présentée au chapitre 3, par exemple dans le fait que pour les cas des œufs organiques et du maïs bio, l'organisation en formes plurielles de type « combo » soit motivée par la combinaison de l'incertitude de marché et de l'incertitude dans l'évaluation des performance, ou dans l'incertitude de marché et l'incertitude technologique.

J'ai par ailleurs compris à l'examen des données recueillies que chacun des types d'incertitude, à lui seul, est une représentation stylisée qui sert á comprendre une réalité plus complexe que ce que le modèle capte. En effet, si on excepte le cas du maïs conventionnel (chapitre 3)concerné seulement par l'incertitude de marché, on ne trouve dans aucun autre cas la présence d'un seul type d'incertitude comme explication suffisante à l'existence et à la variété des formes plurielles. Au moins deux types d'incertitudes jouent un rôle déterminant dans 18 des 24 cas de formes plurielles observées, et dans 16 des cas étudiés on trouve même les trois types d'incertitude.

Comme prévu par le cadre théorique que j'ai proposé, la combinaison de deux ou trois types d'incertitude poussent vers les modalités «between» et «combo» des formes plurielles (chapitres 3 et 4). A cause de la complexité dont j'ai déjà fait état, il n'y a pas de preuve pour $\mathrm{H}_{1 b}$ (où jouerait la seule incertitude technologique) et $\mathrm{H}_{1 \mathrm{c}}$ (où la seule incertitude sur l'évaluation des performances serait déterminante). Cependant, j'ai pu trouver des indications (chapitre 4) tendant à montrer que l'incertitude des marchés pousse vers le type «between » des formes plurielles $\left(\mathrm{H}_{1 \mathrm{a}}\right)$, cette variable différenciant les formes plurielles du groupe « between » des formes non-plurielles. Cependant dans le cas du maïs conventionnel illustré dans le chapitre 3, ce type d'incertitude considéré de façon isolée pousse vers le type « within » des formes plurielles. Etant donné cette divergence, et compte tenu de la nature des observations qui sous-tendent cette observation, il est impossible de conclure à ce stade. En effet, le chapitre 4 comprend un ensemble d'entreprises alors que le chapitre 3, basé sur une 
étude de cas approfondie, présente aussi le seul cas où un type unique d'incertitude détermine les modalités d'organisation de la transaction d'approvisionnement. Le tableau 5 résume mes conclusions á l'égard de mes hypothèses.

Tableau 4. Conclusion

\begin{tabular}{ccc}
\hline Hypothèses & Évidence & Article \\
\hline $\mathrm{H}_{1 \mathrm{a}}$ & Oui & 4 \\
$\mathrm{H}_{1 \mathrm{a}}$ & Non & 3 \\
$\mathrm{H}_{1 \mathrm{~b}}$ & Non & - \\
$\mathrm{H}_{1 \mathrm{c}}, \mathrm{H}_{1 \mathrm{~d}}$ & Non & 3 et 4 \\
$\mathrm{H}_{1 \mathrm{e}}, \mathrm{H}_{1 \mathrm{f}}$ & Oui & 3 et 4 \\
$\mathrm{H}_{1 \mathrm{~g}}, \mathrm{H}_{1 \mathrm{~h}}, \mathrm{H}_{1 \mathrm{i}}$ & Oui &
\end{tabular}

Mes résultats dans le chapitre 4 suggèrent aussi la nécessité d' 'une hypothèse supplémentaire, tenant compte de la combinaison des trois types d'incertitude et d'un niveau intermédiaire de spécificité des actifs: la combinaison des incertitudes élevées (du marché, technologique et de performance) avec la spécificité des actifs intermédiaire pousse vers le type "combo » des formes plurielles. Cette hypothèse supplémentaire repose sur l'observation de ce que le groupe «combo» de formes plurielles présente simultanément les niveaux les plus élevés pour l'ensemble des types d'incertitude, mais aussi pour chaque niveau d'incertitude pris isolément (voir chapitre 4). A cela il convient d'ajouter que dans certains cas, par exemple le cas des œufs et du maïs bio (chapitre 3) les résultats vont dans le même sens : les niveaux d'incertitude les plus élevés conduisent au choix de formes plurielles de type «combo».

En somme, les éléments empiriques que j'ai pu recueillir confortent le modèle théorique et la plupart des hypothèses que j'ai pu en dériver, comme le résume le tableau 6, ci-dessous. En même temps, ces études empiriques ont conduit à ajuster certaines caractéristiques du modèle (notamment concernant le degré d'incertitude) et certaines hypothèses. 
Tableau 5. Conclusions générales

\begin{tabular}{cc}
\hline $\begin{array}{c}\text { Modèle théorique } \\
\text { Hypothèses }\end{array}$ & Confirmé \\
\hline Ajustement (rétrospectif) \\
\hline Modèle théorique & $\begin{array}{c}\text { Seuil d'incertitude } \\
\text { inferieur à ce qui était } \\
\text { anticipé }\end{array}$ \\
Hypothèses & $\begin{array}{c}\text { prévision à ajouter à la } \\
\text { combinaison des } 3 \text { types } \\
\text { d'incertitude }\end{array}$ \\
\hline
\end{tabular}

Je pense ainsi avoir pu fournir des résultats intéressants, compte tenu de ce que j'ai développé une approche théorique novatrice et que j'ai pu établir des observations empiriques relativement riches à l'appui de cette approche. Cependant, comme prévisible, de nouvelles questions se posent et d'autres demeurent sans réponses.

Ainsi, je n'ai pas pu vérifier en les isolant les effets spécifiques de l'incertitude technologique et de l'incertitude liée à l'évaluation des performances. Je n'ai pas pu non plus établir dans quelle proportion différents types de modes d'organisation ont été mis en œuvre en fonction de chaque type d'incertitude lorsque plus d'un type est concerné dans une transaction donnée. Autrement dit, mes données indiquent comment deux ou trois types d'incertitude, ensemble, concernent une transaction donnée (ou un ensemble de transactions) et poussent vers le type «between » ou le type «combo» des formes plurielles. Mais, sur la base des données recueillies, je suis incapable de dire quelles modes d'organisation, parmi ceux qu'on observe, ont été mis en œuvre pour faire face à l'un ou l'autre des types d'incertitude.

Une question en partie reliée à cela concerne la diversité des formes plurielles et surtout le poids relatif de chaque mode d'organisation composant les formes plurielles: pourquoi certaines entreprises combinent-elles l'acquisition de 50\% de leurs 'inputs' sur le marché au comptant et assurent-elles en interne l'autre 50\%, alors que d'autres entreprises du même secteur comptent sur $10 \%$ originant du marché et sur $90 \%$ fourni en interne, bien que toutes les deux fassent usage du même type («between ») des formes plurielles et ont recours aux mêmes modes d'organisation, mais dans des proportions qui sont donc très différentes? 
Une autre piste pour de futures recherches pourrait être l'analyse d'une relation potentielle entre le poids des divers modes d'organisation composant les formes plurielles et les types de formes plurielles en jeu. Par exemple, une distribution plus uniforme de ces poids (par exemple $50 \%-50 \%$, ou 33\%-33-33\%, etc.) pourrait-elle être associée à un groupe particulier de formes plurielles (par exemple. «between » ou « combo ») alors qu'une distribution nonuniforme (par exemple. 90\%- 10\%, ou 10\%-10\%-80\%, etc..) serait associée à un autre groupe de formes plurielles? Si tel est le cas, ce que semblent suggérer certaines des données que nous avons recueillies, alors il conviendrait de s'interroger sur les raisons de ces variations.

Ces questions, parmi d'autres, indiquent la richesse du programme de recherche sur les formes organisationnelles plurielles, un programme de recherche qui ne s'est ouvert que très récemment. 


\section{Chapter 1}

\section{General introduction}

This dissertation addresses an important empirical regularity carrying various labels: plural forms (Bradach \& Eccles, 1989, Menard, 2013), tapered integration (Harrigan, 1983), dual distribution (Dutta, Bergen, Heide \& John, 1995; Bai \& Tao, 2000; Mols, 2000; Penard, Raynaud \& Saussier, 2003), concurrent sourcing (Parmigiani, 2007; Mols, 2010), plural sourcing (Puranam, Gulati \& Bhattacharya, 2013; Krzeminska, Hoetker \& Mellewigt, 2014), hybrid channels (Rangan, Corey \& Cespedes, 1993), multiple channels (Anderson, Day \& Rangan, 1997), hybrid marketing systems (Moriarti \& Moran, 1990), partial integration (Adelman, 1949; Carlton, 1979) or contractual mix (Bai \& Tao, 2000).

In all the cases described in these different labels, the idea remains the same: the same firm, in a given institutional context, simultaneously relies on different organizational arrangements to govern similar (or identical) transactions.

This phenomenon was first observed in the 80's in the franchising context, since many (most) franchisors simultaneously rely on franchised and company-owned units to distribute their products (see among others, Azevedo and Silva, 2007; Lafontaine, 1992; Lafontaine and Shaw, 2005). And this remains to date the most prominent example of the phenomenon.

Similar combinations have been later found in various other (upstream and downstream) sectors. For instance, Parmigiani (2007) and Parmigiani and Mitchell (2009) found that the sourcing of metallic components to the tooling industry is made both by making and buying. Going beyond the procurement or the distribution of products, Nickerson and Silverman (2003) and He and Nickerson (2006) also found plural forms in the provision of services (trucking in their analyses).

However, as I will demonstrate in chapter 2, the most relevant theories of the firm, namely Transaction Cost Economics (TCE), the modern Property Rights Theory (PRT) and the 
Resource Based View of the firm (RBV) have difficulties in explaining the mere existence of the phenomenon, because they defend the superiority of a single organizational arrangement to govern each transaction.

I also show that given this 'challenge', a number of different theoretical explanations have emerged over time, although there is no consensus to date on the motivators for this coexistence of arrangements. To say it differently, the motivations pushing towards these findings are still not very well understood, making room for interesting theoretical contributions. And this is why I choose to address it in this dissertation.

Empirical studies also show that the coexistence of organizational arrangements goes beyond the combination of markets and hierarchies (Veugelers \& Cassiman, 1999; Krzeminska et al, 2014). As described later in Menard, Saes, Silva \& Raynaud (2014), some firms combine more than two organizational arrangements for the same transaction (for instance spot market, formal contracting and vertical integration) and can even combine both various arrangements and alternative declinations of similar governance (for instance different types of formal contracts). For instance, Delfi, an important player in the Brazilian cocoa industry, obtains $45 \%$ of its cocoa beans with relational contracts, $50 \%$ with long term formal contracts and $5 \%$ is obtained by means of medium term formal contracts (Menard et al, 2014).

Despite this variety of manifestations, very little is known about the motivations for one or another combination. In fact, as far as I could tell, there is to date only a single paper (Puranam, Gulatti \& Battcharia, 2003) addressing how much should be made and how much should be bought; but this largely neglects other potential combinations. Therefore, I choose to address this issue in chapters 3, 4 and 5 of this dissertation.

\subsection{Operational definition and transaction at stake}

The coexistence of organizational arrangements to govern similar (identical) transactions carries various labels, but I will follow Bradach \& Eccles (1989) and Menard (2013) and treat it as 'plural forms'. I make this choice because I perceive of this label as more general than the others, in the sense that it could be used in the context of both upstream and downstream transactions. However, I should mention that in the empirical contributions presented in this 
dissertation, I am solely concerned with the procurement of inputs and therefore, in these papers, the term will refer to upstream transactions only.

\subsection{Objectives and structure of the dissertation}

This dissertation is composed of four chapters, besides this introduction and the conclusion. Each chapter is a paper, providing different but complementary approaches to plural forms: the first half of this dissertation remains theoretical, while the second presents distinct qualitative empirical contributions on the theme. Each paper has a unique research-question related to plural forms and is intended to be published individually and independently of the others. Nonetheless, because they are in fact tightly related, there will be some overlap in their contents. Figure 1, below, summarizes the relationships between the four papers composing this dissertation.

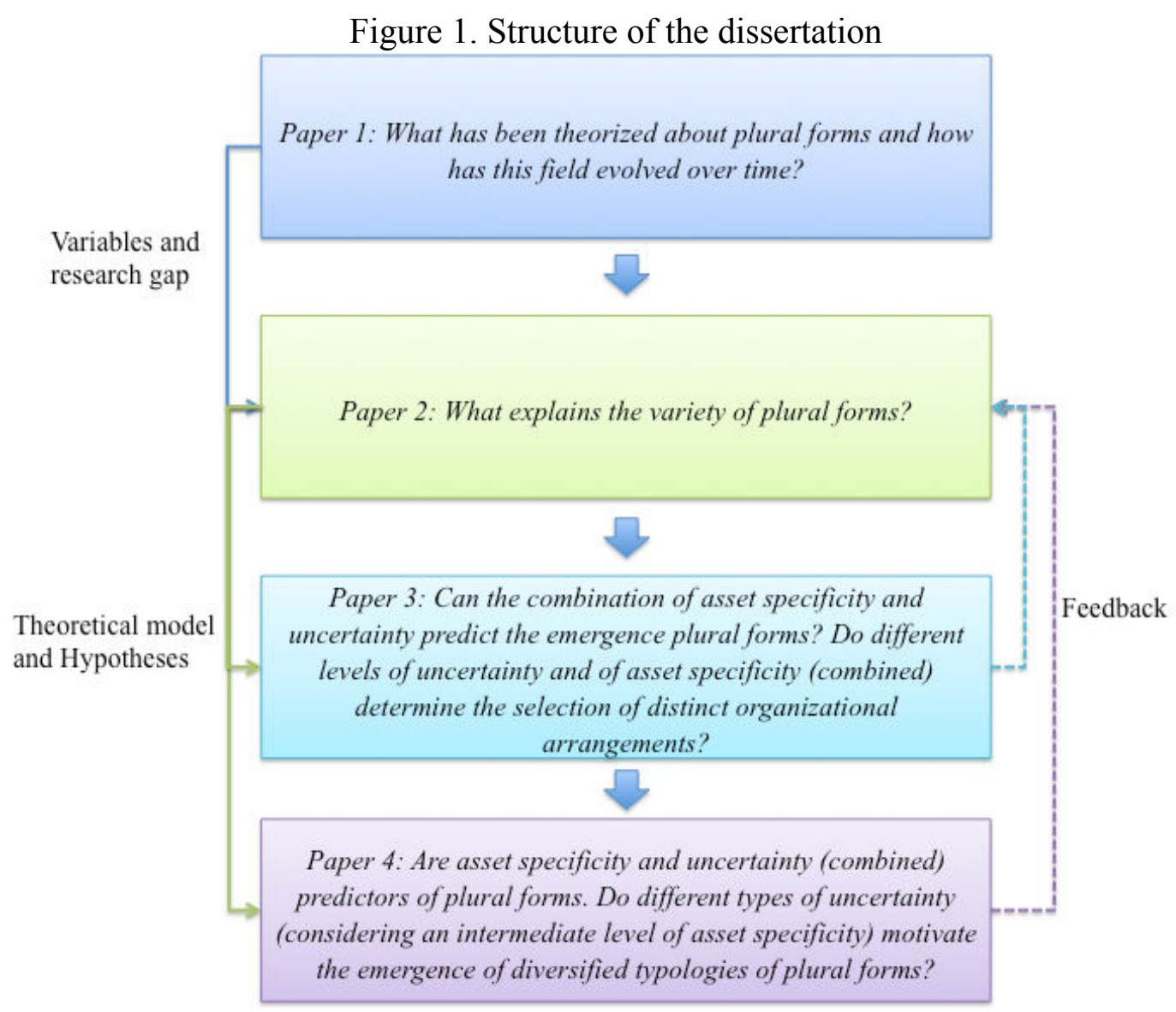

The basic notion expressed in this figure is that each paper serves as in input for the next, with the exception of paper 3. In that respect, notice that the bibliographic survey in paper 1 feeds 
the development of the theoretical model in paper 2 by expressing potential gaps and variables of interest. This second paper provides the theoretical background that supports both papers 3 and 4. Finally, these two empirical contributions provide some feedback to the theoretical model. To clarify these relationships, I briefly summarize what will be done in each of the papers in the next subsections.

\subsubsection{Paper 1}

The main theories of the firm defend the superiority of a single organizational arrangement over its alternatives. But, if a single arrangement is the most efficient one, why should two (or more) of them be simultaneously combined to organize similar (or identical) transactions? This is the question that motivated the development of the first paper.

Basically, I intend to verify what has been theorized about plural forms and how this field evolved over time. I am especially concerned with the multiple theoretical explanations about the reasons why firms adopt plural forms, mainly because, to date, there is no consensus on the subject.

Therefore, in this paper, I first survey the ISI Web of Science platform to identify available articles. I collect metrics such as the number of publications per year and the number of citations per paper, and find some interesting results about the origins of the field and about its growth. I also identify the most relevant publications on the subject.

In a more qualitative perspective, in the second part of the paper I review some significant contributions on plural forms. I organize these contributions as to understand the evolution of the explanations for the existence of plural forms over time. I find that although in the very beginning plural forms were treated as a transitory phenomenon, they soon became recognized as a stable issue and caught the attention of organization scientists seeking for explanations based on the theories of the firm to clarify them.

I could identify, from the theoretical survey, that asset specificity together with multiples types of uncertainty are interesting variables to explain the existence and stability of plural forms. Nonetheless, they remain very poorly explored, making room for novel contributions 
in that respect. Another potential field that I could identify for further research is the variety of plural forms. I could see that although they are not uniform, but compose a very heterogeneous set of potential combinations, there are almost no contributions attempting to understand such variety. Thus, I use these finding to feed the theoretical model and the hypotheses I develop in paper 2.

\subsubsection{Paper 2}

The second paper composing this dissertation is the core of my work. Not only is it my own original theoretical contribution, but it also feeds the next two empirical chapters.

I stress that very little has been specifically said about the composition of the plural form and about their variety and therefore, I seek to shed some light on the variety of plural form manifestations; i.e. the diversity of the combinations of organizational arrangements composing the plural form. Hence, I intend to provide an answer to the following question: What explains the diversity of plural forms?

Although my concept of diversity includes all the possible combinations of organizational arrangements that are simultaneously used in order to obtain a given input, I choose to keep the argumentation tractable and group them into three subsets: those involving different classes of organizational arrangements (make-and-buy, make-and-ally, buy-and-ally, makebuy-and-ally), those addressing multiple categories of hybrid arrangements (ally-and-ally), and finally, those dealing with a combination of the two groups mentioned above (make-allyand-ally, buy-ally-and-ally, make-buy, ally-and-ally).

I should also mention that in order to understand the motivations underlying this wide variety of plural forms, I first had to take a step back and build a theoretical model to predict when plural forms should or should not be observed. In doing so, I follow Parmigiani (2007), Krzeminska (2008) and Menard $(2013,2014)$ to propose an integrative model of asset specificity and uncertainty (variables identified in paper 1 as potential motivators for plural forms) to predict plural forms and their variety. This model extends existing literature in that it allows for predictions rather than explanations for the existence or not of plural forms. 
Given the predictions shown in my model, I build some theoretical hypotheses to clarify the variety of plural forms. In particular, I associate multiple types of uncertainty (namely, market, technological and performance assessment) to the three sets of plural forms previously defined, keeping constant and at an intermediate level the degree of asset specificity.

My hypotheses predict the circumstances under which each type of plural forms should emerge and be efficient; and therefore, they might assist decision-makers in deciding what combination of organizational arrangements better suits the conditions under which they operate. This might help explain why some transactions are carried out by using one or another combination, or even clarify why different companies, operating in the same sector and institutional environment, use different combinations of organizational arrangements to govern their transactions.

Although I remain strictly theoretical in this paper, I confront my model and hypotheses in the next two papers, of empirical nature. As I will describe next, they provide complementary views, finding support for my ideas: while I perform an embedded clinical case study (Yin, 2003; Baker \& Gil, 2013) on the third paper, I conduct a qualitative survey of 24 companies on the fourth paper.

\subsubsection{Paper 3}

This is the first paper to empirically confront the theoretical model developed in paper 2 , associating asset specificity and uncertainty to plural forms. Therefore, I first intend to provide an answer to the following question: can the combination of asset specificity and uncertainty predict the emergence plural forms?

I also intend to push my model further and verify whether or not different levels of uncertainty and of asset specificity (combined) determine the selection of distinct organizational arrangements. To say it in a different way, not only am I interested in verifying whether each transaction falls within or outside the plural form region defined in my model (see paper 2), but also in assessing how these different transactions (namely, the procurement 
of products bearing different levels of asset specificity and uncertainty) can be distributed along my model.

To this end, I perform an embedded clinical case study (Yin, 2003; Baker \& Gil, 2013) on the Korin company. This choice was motivated by the fact that it procures a number of different products, both by means of non-plural and of plural forms. Therefore, the embedded clinical case will provide me with an understanding as to why Korin adopts plural forms to procure some products, but turns to non-plural forms to procure others. Moreover, by analyzing different products, I can compare their distribution in my model.

Despite the qualitative and exploratory nature of this paper, I manage to find indications in favor of the model developed in paper 2. I should mention, however, that in important limitation of my technique is the generalizability of these results: they are of course valid for Korin, but do they hold for other companies?

\subsubsection{Paper 4}

In the final paper in my dissertation, I seek to confront both the model and the hypotheses developed in paper 2. Therefore, I seek to answer the following questions: i. Are asset specificity and uncertainty (combined) predictors of plural forms? and ii. Do different types of uncertainty (considering an intermediate level of asset specificity) motivate the emergence of diversified typologies of plural forms?

To this end, I survey the procurement of inputs by 24 companies operating in the Brazilian Agribusiness sector and procuring 11 different inputs. To qualitative assess the managers' perceptions about multiple types of uncertainty and about asset specificity, I make use of a 4point likert scale questionnaire.

I use these data to perform an exploratory and essentially qualitative comparative set of analyzes, relying mostly on descriptive statistics. After all, my sample does not allow me to perform more sophisticated statistical analyzes. However, because this is the first paper to assess both my model and hypotheses, a qualitative set of analyzes is already an important contribution. 
Despite all the limitations, and find supportive evidence for my model and hypotheses. And they are more generalizable then those shown in paper 3 because they cover a larger number of companies.

\subsection{The building of this dissertation and the English language}

This dissertation was written in the context of a 'cotutelle' (dual-degree) agreement between the University of Sao Paulo and the University of Paris 1- Pantéon - Sorbonne. The agreement allowed me to develop a considerable part of this work while I spent the academic year of 2013-2014 in Paris, with the generous financial support of FAPESP.

I also had the privilege of being directed by two outstanding advisors: Claude Menard (Paris 1) and Maria Sylvia Macchione Saes (USP), besides discussing my work with other specialists in the field, such as professors Emmanuel Raynaud (INRA) and Niels Peter Mols (Aarhrus), as well as with other professors and students both in Paris and in Sao Paulo.

Hence, in order to facilitate my communication with both the French and the Brazilians, I found the need to write my dissertation in English. 


\section{Chapter 2}

\section{Organization theory and plural forms: past, present and future directions}

\subsection{Introduction}

The most distinguished theories of the firm, namely Transaction Cost Economics (TCE) and the New Property Rights Theory (NPRT), in general terms, seek to determine the efficient firm boundaries. In other words, they attempt to determine, for each transaction, what the most efficient mode of organization is. In most of the works belonging to each of these theoretical streams there is always a unique solution, namely one organizational arrangement always outperforms the others (for a given set of transactional attributes). This means that, according to these theories, companies would either buy/sell items on the spot market; or uniformly contract for their production/distribution or produce/distribute the inputs/products themselves (Williamson, 1985, 1991).

However, in the 'real world', many firms quite often combine alternative organizational arrangements for the same type of transactions within a given institutional environment. Depending on the focus of analysis, this phenomenon carries various labels, plural form (Bradach \& Eccles, 1989; Menard, 2013), tapered integration (Harrigan, 1983), dual distribution (Dutta, Bergen, Heide \& John, 1995; Bai \& Tao, 2000; Mols, 2000; Penard, Raynaud \& Saussier, 2003), concurrent sourcing (Parmigiani, 2007; Mols, 2010) or plural sourcing (Puranam, Gulati \& Bhattacharya, 2013; Krzeminska, Hoetker \& Mellewigt, 2014); but the idea remains the same: the same firm in a given institutional context relies on different modes of governance for similar ${ }^{4}$ (or identical) transactions (i.e.: multiple transactions

\footnotetext{
${ }^{4}$ For a richer discussion on the similarity of transactions in plural forms, refer to Krzeminska et al (2014).
} 
presenting the same attributes), suggesting that the governance landscape is richer than previously believed ${ }^{5}$.

This phenomenon was first theorized about by Bradach and Eccles (1989), who formally introduced the term 'plural form' by submitting that they constituted "an arrangement where distinct organizational control mechanisms are operated simultaneously for the same function by the same firm" (Bradach \& Eccles, 1989: 112). The most prominent example is probably the franchising case, in which many (most) franchisors simultaneously rely on franchised and company-owned units to distribute their products (see among others, Azevedo and Silva, 2007, Lafontaine, 1992, Lafontaine and Shaw, 2005) ${ }^{6}$.

Similar combinations have been found in various other (upstream and downstream) sectors. For instance, Parmigiani (2007) and Parmigiani and Mitchell (2009) found that the sourcing of metallic components to the tooling industry is made both by making and buying ${ }^{7}$. Going beyond the procurement or the distribution of products, Nickerson and Silverman (2003) and He and Nickerson (2006) also found plural forms in the provision of services (trucking in their analyses).

Empirical studies also show that the combination of organizational arrangements goes beyond the combination of markets and hierarchies (Veugelers \& Cassiman, 1999; Krzeminska et al, 2014). As described later in Menard, Saes, Silva \& Raynaud (2014), some firms combine more than two organizational arrangements for the same transaction (for instance spot market, formal contracting and vertical integration) and can even combine both various organizational arrangements and alternative declinations of similar arrangements (for instance different types of formal contracts).

\footnotetext{
${ }^{5}$ As recently stressed by Baker, Gibbons and Murphy (2008), “....firms have invented far more ways to work together than organizational economics has so far expressed (not to mention evaluated)" (p. 147).

${ }^{6}$ Similarly, Dutta et al (1995) and Heide (2003) found the simultaneous use of direct sales and third parties' distribution channels for the same products. For instance, the toy producer LEGO combines its third parties' distribution channels with its own, Internet-based, channels (Mols, 2000). And this coexistence of distribution channels has even been considered a dominant marketing design! (Moriati \& Moran, 1990).

${ }^{7}$ Parmigiani (2007) called this 'concurrent sourcing' (Mols, 2010), which is roughly a plural form. Other frequently used and related terms include hybrid channels (Rangan, Corey \& Cespedes ,1993), multiple channels (Anderson, Day \& Rangan, 1997), hybrid marketing systems (Moriarti \& Moran, 1990), tapered integration (Harrigan, 1984), dual distribution (Bai \& Tao, 2000; Mols, 2000), partial integration (Adelman, 1949; Carlton, 1979) and contractual mix (Bai \& Tao, 2000; Azevedo \& Silva, 2012a)
} 
The above-mentioned examples are depicted in the simplified representation of two bundles of similar transactions, shown in Figure 2. The dotted line in A denotes the part of the production that is integrated to firm 2, while that in B expresses the portion of the distribution belonging to firm 1 . In both cases, some of the production/distribution is held by other agents, either on the market, or by means of different types of contracts; or still, through a combination of several organizational arrangements to obtain/distribute similar inputs/products ${ }^{8}$.

Figure 2. Schematic representation of the plurality of governance structures in the procurement of inputs (A) and on the distribution of products (B).

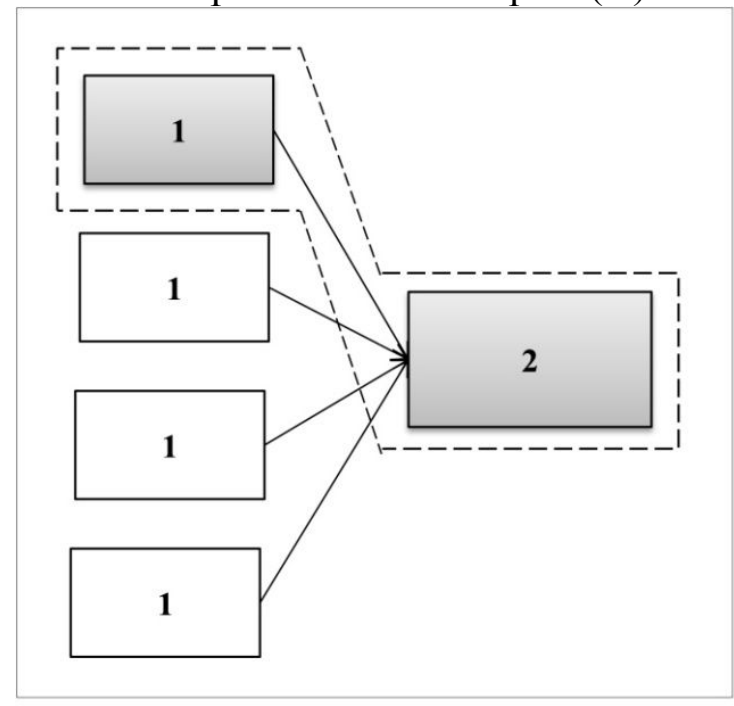

A

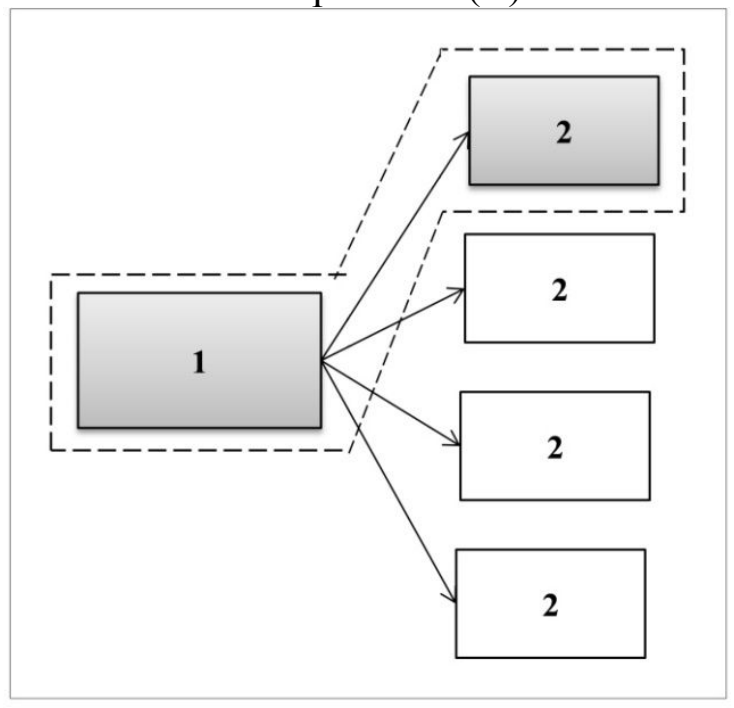

B

Source Retrieved from Schnaider, Raynaud \& Saes (2014, p.37).

All in all, these empirical findings show the relevance and preponderance of plural forms as a 'real' mode of organization; even if they contradict the 'mutually exclusive organizational arrangement decision' view of various approaches in the field of organizational economics (Gibbons \& Roberts, 2013).

Bearing in mind the preponderance of this "anomaly" to the mainstream organization theory, in this paper, we address the following questions: What has been theorized about plural forms? How has the literature on this issue evolved over time?

\footnotetext{
${ }^{8}$ For illustration purposes, we have chosen to emphasize the "make and buy" combination, although several other possibilities might exist, as previously discussed.
} 
To this end, we survey the literature, both trough bibliometric techniques and by reviewing significant publications in this field; and as a result, we critically summarize the evolution of the theoretical contributions drawing on plural forms. We conclude by shedding some light on developments yet to come.

\subsection{A brief literature overview - an exploratory bibliometric survey}

The plural form phenomenon composes a rather recent research agenda. The first papers addressing this issue were published in 1970's ${ }^{9}$ (Oxenfeldt \& Kelly, 1969; Ozanne \& Hunt, 1971; Hunt, 1972, 1973, 1977; Caves \& Murphy, 1976; Lillis, Narayana \& Gilman, 1976) and 1980's (Martin, 1988; Bradach \& Eccles, 1989) and since then, this field has been increasingly drawing the attention of scholars in both management and organizational economics domains.

In a recent exploratory survey carried out on the ISI Web of Science Platform by using the terms "plural forms ${ }^{10}$ ", "franchising", "taper integration", "concurrent sourcing" and "dual distribution"; that have been published since the 70 's, solely in journals related to management, organization and economics ${ }^{11} ; 182$ articles were found, after having removed those papers that were not related to our interest ${ }^{12}$.

As depicted in Figure 3, only a small share of these papers were published during the 70's and 80 's. Interestingly, most of these contributions have been made either in the early 70's (for instance, those by Ozanne and Hunt (1971) and by Hunt $(1972,1973)$ ) or in the late 80's (for instance, those by Martin (1988) and by Bradach and Eccles (1989)).

\footnotetext{
9 Although the term "plural form" only appeared in the late 80's, with Bradach and Eccles' (1989) seminal definition.

${ }^{10}$ For both "plural form" and "franchising", an asterisk $(*)$ has replaced the last character, such as to represent any group of characters, including no character. This has expanded our search, for instance, to include the terms "plural forms", "franchise", "franchisees" and so on so forth.

${ }^{11}$ In particular, we have surveyed the following journals: American Economic Review, Applied Economics, European Journal of Marketing, Industrial Marketing Management, International Journal of Industrial Organization, International Marketing Review, Journal of Business Economics And Management, Journal of Economics \& Management Strategy, Journal of Industrial Economics, Journal of Institutional And Theoretical Economics-Zeitschrift Fur Die Gesamte Staatswissenschaft, Journal of International Marketing, Journal of Law Economics \& Organization, Journal of Management, Journal of Marketing, Journal of Marketing Research, Journal of Retailing, Journal of Services Marketing, Journal of the Academy of Marketing Science, Management Decision, Management Science, Marketing Science, Organization Science, Rand Journal of Economics, Review of Industrial Organization, Strategic Management Journal.

${ }^{12}$ Namely, industrial organization literature analyzing monopoly power in the franchise of utilities which is not in the core of our interest.
} 
During the 90's, significant advances have been made, as the number of publications in the field grew more than 4 times if compared to the number of publications in the 80 's, and almost doubled, if compared to those in the preceding 20 years. Increases in the number of publications in the field have followed in the 2000's, although with much smaller growth rates, since the number of articles published in the 2000's was almost the same as those in the 1990's.

From 2010 to 2014, a very sharp increase in the number of articles on plural forms took place, since 62 papers were published in this period. This figure corresponds to an average of 12.4 articles per year, compared to an average of 4.65 in the preceding 20 years and 1.4 in the 70 's and 80 's. This is quite a remarkable difference.

Figure 3. Number of articles per decade.

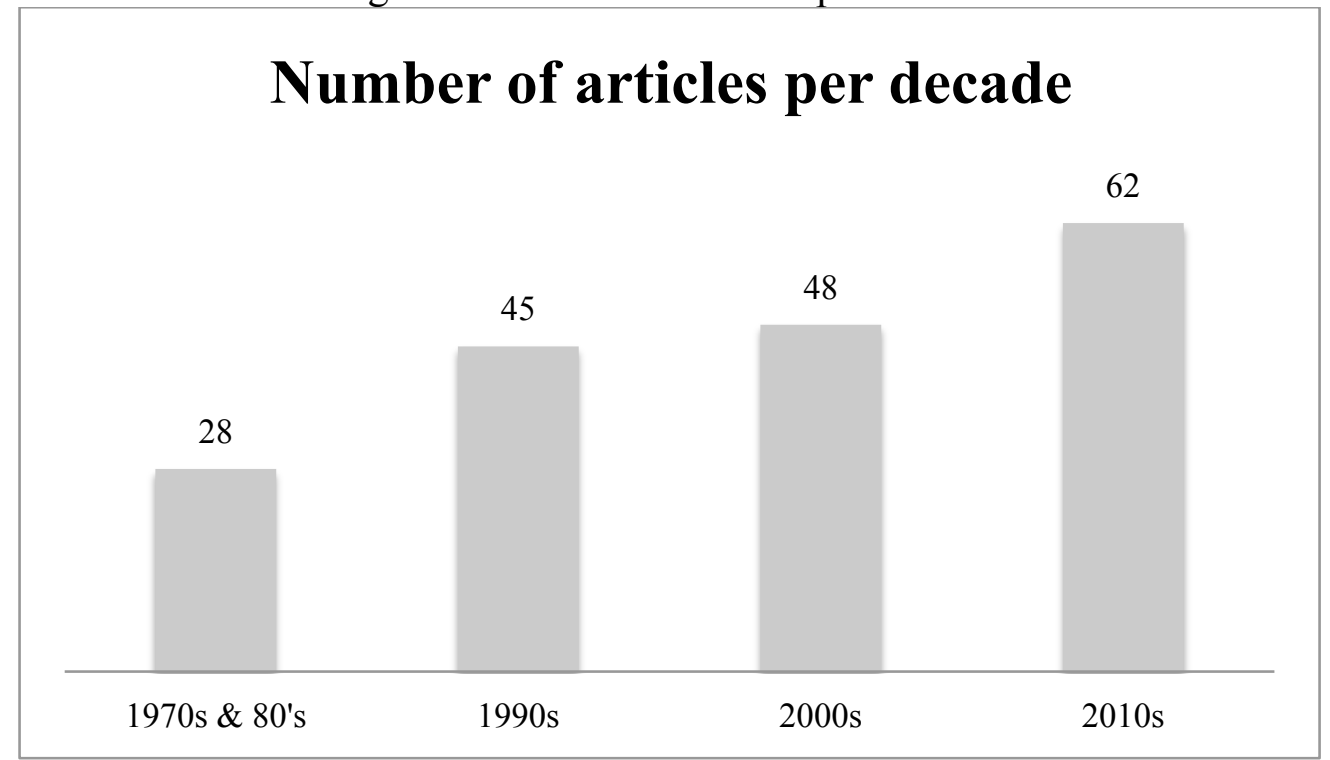

Source: Based on data retrieved from the ISI Web of Science platform (2014)

Going beyond the growth in the number of publications, the importance of the contributions made in the later years deserves to be stressed. In this respect, notice that over $30 \%$ of the 20 most cited papers that have been published during our entire timespan (see Table 1) were published between 2000 and 2006. This is a considerable figure, given that older papers are more likely to have more citations than recent contributions.

First, because they have been available for longer, more scholars will be familiar with these contributions. Second, because it takes quite some time to find out new publications and to 
actually use them in active research, more recent papers will likely have less citations than earlier ones. Finally, because the review process in top tier journals is often time consuming, one should expect a lag between the actual citation and its publication. Therefore, very recent contributions are very unlikely to have been highly cited.

This is why papers that were published in 2013 or 2014, for instance, are by far less likely to appear on this list than those that were published in the 80's or 90's. This might help explain why papers published after 2010 only appear in the bottom end of the full-fledged list of the most highly cited papers (take for instance, those by Krzeminska et al (2013) and by Heide, Kumar \& Wathne (2014), having no citations so far).

Table 6. 20 most highly cited publications between 1970 and 2014

\begin{tabular}{lcc}
\hline \multicolumn{1}{c}{ Most cited papers } & Citations & Average \\
\hline Darr, Argote \& Epple (1995) & 382 & 20,11 \\
Lafontaine (1992) & 328 & 14,91 \\
Winter \& Szulanski (2001) & 241 & 18,54 \\
Lal (1990) & 181 & 7,54 \\
Cannon, Achrol \& Gudlach (2000) & 155 & 11,07 \\
Mcafee \& Schwartz (1994) & 147 & 7,35 \\
Martin (1988) & 116 & 4,46 \\
Lee \& Staelin (1997) & 113 & 6,65 \\
Carney \& Gedajlovic (1991) & 110 & 4,78 \\
Fladmoe- Lindquist \& Jacque (1995) & 103 & 5,42 \\
Dant \& Schul (1992) & 102 & 4,64 \\
Sorenson \& Sorensen (2001) & 100 & 7,69 \\
Gallini \& Lutz (1992) & 95 & 4,32 \\
Rothaermel \& Hitt (2006) & 87 & 10,88 \\
Dahlstrom \& Nygaard (1999) & 86 & 5,73 \\
Lafontaine \& Kaufmann (1994) & 86 & 4,30 \\
Combs \& Ketchen (2003) & 79 & 7,18 \\
Lafontaine \& Slade (1997) & 79 & 4,65 \\
Yin \& Zajac (2004) & 78 & 7,80 \\
Porteus \& Whang (1991) & 77 & 3,35 \\
Szulanski \& Jensen (2006). & 72 & 8,00 \\
\hline
\end{tabular}

Note. Based on data retrieved from the ISI Web of Science (2014) 
Also, even though the publications made available after 2000 have been outnumbered by earlier articles; one can realize by analyzing Table 1 that these papers, as a group, have averaged over 10 citations per year; while the earlier set of articles have averaged roughly 7 . These figures could very much constitute a proxy for the impact of these contributions over time. Once again, our argument in favor of the crucial advances that have been made since 2000 has been supported by bibliometric data.

In a more qualitative perspective on these publications, it can be easily verified that the vast majority on the articles composing our "top 20 list" regard the franchising field (as mentioned before, most franchise chains combine company owned units with franchised outlets), even though a variety of distinct approaches can be found. For instance, some have focused on the motivations driving this mode of organization (Martin, 1988; Carney, 1991; Gallini \& Lutz, 1992; Fafontaine, 1992; Lafontaine \& Kaufmann, 1994; Combs \& Ketchen, 2003), others have regarded organizational aspects within franchise chains, such as knowledge creation and sharing and the performance implications of the selected mode of organization (Darr et al, 1995; Cannon at al, 2000; Sorenson \& Sorensen, 2001; Winter \& Szulanski, 2001; Yin \& Zajac, 2004), or even dealt with contractual issues and/or characteristics within franchising (Mcafee \& Schwartz, 1994; Lafontaine \& Slade,1997; Dahlstrom \& Nygaard, 1999).

Also, it is worth noting that most of the contributions composing the list shown in Table 1 are empirical investigations of the franchising aspects mentioned before (Carney \& Gedajlovic, 1991; Dant \& Schul, 1992; Lafontaine, 1992; Lafontaine \& Kaufmann, 1994; Darr et al, 1995; Fladmoe-Lindquist \& Jacque, 1995; Lafontaine \& Slade, 1997; Dahlstrom \& Nygaard, 1999; Sorenson \& Sorensen, 2001; Yin \& Zajac, 2004). Not surprisingly, the vast majority of these articles have been published either in management or in marketing journals ${ }^{13}$.

In a more general way, franchising literature dominates our entire sample of articles. As a matter of fact, the authors that have published the most in our database, including coauthorships, are Rajiv Dant, Scott Weaven, Francine Lafontaine, Shelby Hunt, Debra Grace, Patrick Kaufman and Arturs Kalnins. All of which are writing about franchising. Moreover, the words "franchise", "franchising", "franchisor(s)" or "franchisee(s)" have appeared in the

\footnotetext{
${ }^{13}$ In particular, in the following journals: Journal of Management, Journal of Marketing, Journal of Marketing Research, Journal of Retailing, Journal of the Academy of Marketing Science, Management Science, Marketing Science, Organization Science, Strategic Management Journal
} 
titles of 133 articles, in our list of 182 papers. This represents almost $75 \%$ of our entire database.

After all, as we shall later describe, until the late 80's and 90's, there were almost no works on plural forms other than franchising theory. It is only in more recent years that scholars have identified plural forms in other types of organizations (as described in the introduction of this paper) and attempted to provide novel explanations for their findings. Hence, in the next subsections, we survey some of the most well-known articles in plural forms and provide a historical perspective of the evolution of the theoretical advances in this field.

\subsection{The early days: plural forms as a transitory phenomenon}

The very first debate concerning the use of plural forms has been motivated by the governance of franchise chains. As pointed out before, many (most) franchise chains combined both company-owned and franchised units. Early contributions in the field submitted that this finding constitutes a transitory (short run) issue (Oxenfeldt \& Kelly, 1969; Ozanne \& Hunt, 1971; Caves \& Murphy, 1976; Gallini \& Lutz, 1992; Scott, 1995; Dant, Paswan \& Kaufman, 1996), where a single mode of organization should prevail in the long run.

Nevertheless, these contributions subscribed to distinct arguments and even predicted different prevailing governance structures. For instance, according to Oxenfelt and Kelly (1969) and Caves and Murphy (1976), franchisors rely on franchisees to obtain the resources that are required in order to expand the network at a low cost. These scare resources are either (Caves \& Murphy, 1976), managerial talent (Scott, 1988) or local information (Minkler, 1990). However, with the passing of time (and an increasing economic success), chains could more easily develop these resources internally. That would justify the reacquisition of franchised stores and the convergence toward fully owned chains (something called ownership redirection in the franchise literature). A very similar explanation has been provided by Ozanne and Hunt (1971) and by Dant et al (1996). In different terms, these contributions determine that the availability and the cost of the necessary resources would drive plural forms to be a transitory phenomenon. A testable implication is that as chains become established and valuable, the reliance on franchised units should reduce. 
By analyzing empirical data on franchise chains, however, Lafontaine and Kauffman (1994) have later scrutinized this perspective, while Combs and Ketchen (2013) have found no support for it in a meta-analysis aggregating results from 44 studies and 140 tests of ten hypotheses.

Other early contributions rely on Agency Theory to predict the progressive convergence of franchised chain toward pure franchised chains with no vertical integration because franchised units are more profitable than company-owned ones. This is the point made by Gallini and Lutz (1992) and by Scott (1995), which argue that franchisors initially make use of their own stores to signal the profitability of the business and attract new franchisees to their chains ${ }^{14}$. However, over time, as the brand name becomes reputable in the market, the signaling device is no longer needed and company-owned units are likely to be sold to franchisors, bearing higher powered incentives. One of the consequences is that the extent of company ownership should decrease with chain maturity.

Beyond the divergence of predictions pointed out before, the most prominent theories of the firm, namely transaction cost economics (Williamson, 1985, 1991) and the new property rights theory (Grossman \& Hart, 1986; Hart, 1995) experience difficulties to explain the mere existence of plural forms. In the latter, organizational arrangements are defined in terms of the allocation of (residual) rights of control over the assets involved in the transaction. It then focuses on how the allocation of ownership over the assets involved in the relation, which confers residual rights of control over them, alters the efficiency of the business relation. The theory then predicts what should be the most efficient organizational arrangement (mostly make or buy) for a given set of circumstances. Nowhere in the theory is the possibility of having more than one organizational arrangement for the same set of circumstances explicitly taken into account.

To put it differently, alternative allocations of ownership can coexist only if they govern relations with different economic environment. This also holds for transaction cost economics (Williamson, 1985, 1991). The diversity of observed organizational arrangements is driven by the diversity of transactional attributes (asset specificity, frequency and uncertainty) and/or by

\footnotetext{
${ }^{14}$ The argument runs as follows: franchising is the dominant organizational arrangement because of its incentive properties. However, in order to attract new franchisees, chains need to credibly convey information about the value of the brand to new applicants. One way to signal the value of the brand is to directly have a stake in the business by owning some stores.
} 
the diversity of the institutional and competitive environments. Once these factors are fixed, firms should rely on the most efficient mode of organization - the one that best economizes on transaction costs. ${ }^{15}$ Here again, standard TCE reasoning leaves no room for the coexistence of alternative modes of organization governing similar (identical) transactions.

Rather, as shown by Shelanski and Klein (1995) and by Macher and Richman (2008), there are numerous empirical studies supporting the "discriminating alignment hypothesis" (Williamson, 1991), even though some have actually found the coexistence of organizational modes, but considered the dominant mode of organization (i.e., the one corresponding to the largest share of the procurement/distribution) as the efficient organizational solution. And therefore, they have found strong support for TCE predictions; even if the evidence did not indeed prove to be as supportive as previously believed to explain pure forms.

For instance, in their seminal empirical study on the automobile industry, Monteverde and Teece (1982) coded each component as made or bought, based on the percentage of the inputs that were obtained in house or purchased. Although not always were $100 \%$ of the components coded as made (bought) produced in-house (outsourced), the mere fact that the vast majority of these inputs were obtained in one or the other way sufficed in order for this item to be coded as entirely made or bought. In different terms, the coexistence of organizational solutions has been heavily neglected in this and other early contributions finding large support for TCE predictions.

One way to introduce plural forms in this analysis is to consider that firms are uncertain about the respective costs and benefits of alternative organizational arrangements and/or about the transactional attributes. They combine organizational arrangements in order to discover the most efficient one ${ }^{16}$. However, modifying the existing organizational arrangement is not necessarily an easy (and cost-free) process. There could be path-dependence (David, 1985; Arthur, 1988, 1989) in the organizational arrangement. ${ }^{17}$ For instance, converting a vertically integrated facility into a bundle of outsourced contracts might not be a straightforward action, being that it is required that firms sell existing productive assets and consequently, find

\footnotetext{
${ }^{15}$ This is perfectly illustrated by what Williamson (1991:79) called the discriminating alignment hypothesis: "[...] align transactions, which differ in their attributes, with governance structures, which differ in their costs and competencies, in a discriminating (mainly, transaction cost economizing) way".

${ }^{16}$ That would be consistent with the bounded rationality assumption.

${ }^{17}$ This has been called governance inseparability by Argyres and Liebeskind (1999).
} 
suitable buyers willing to paying a fair amount for them. And this process does not instantaneously take place: it could last for a long time, as the transition is carried out; and therefore, previous arrangements can coexist with the new, more efficient organizational arrangements (see Zylbersztajn \& Nogueira, 2002).

To sum up, even if the above-mentioned, early explanations did not predict the same resulting organizational arrangements, they most certainly agreed on the fact that plural forms are transitory and therefore, should disappear as the organization becomes more mature and/or as the environmental and/or transactional characteristics are gradually modified. However, as we shall argue next, subsequent analytical developments have strongly mitigated these views.

\subsection{Stable plural forms: an evolution}

A crucial evolution in the plural forms debate consisted of the recognition of this mode of organization as a stable phenomenon, i.e., its persistence over time. Franchising provides again a striking example. For instance, one of the most relevant results in Lafontaine and Shaw (2005) is the fact that most US chains combine both company-owned and franchised units over time. ${ }^{18}$

Drawing on the stable coexistence of company-owned outlets and franchised stores, these contributions compose a large body of literature, encompassing various theoretical arguments; even if some have stood out more than others (see Table 2 for an overview of the number of citations received by each theoretical stream). This is the case of the two leading and somehow complementary streams in the field: complementarities and incentives ${ }^{19}$.

The former theory has gained relevance since Bradach (1997), who explicitly and strongly emphasizes - using qualitative evidence - the complementarities gains brought by combining different structures to the four 'franchising imperatives': system growth, chain uniformity,

\footnotetext{
${ }^{18}$ They observe that within the first 8 years of experience in franchising, there is a drastic adjustment in the percentages of company-owned and franchised outlets. However, after this period, franchise chains would be likely to use an optimal stable combination of company-owned and franchised units. Even if this proportion is likely to vary according to the sector in which firms operate, Lafontaine and Shaw (2005) find that, on average, franchise chains operating in the USA and Canada directly controlled about $15 \%$ of their stores. Azevedo \& Silva $(2001,2007)$ found a similar result for franchise chains in Brazil.

${ }^{19}$ We group into this category those papers based on the Agency Theory, on monitoring and control arguments, on signaling devices, on asymmetric information and on incentives themselves. These theories stand out both in terms of the amount of publications and of the number of citations received.
} 
local responsiveness, and systemwide adaptation (Bradach, 1997, 1998; Meiseberg, 2013) ${ }^{20}$. In this respect, Bradach $(1997,1998)$ argues (and Cliquet and Penard (2012) and Meiseberg (2013) further verify) that both company-owned units and franchised outlets present contrasting advantageous and disadvantageous characteristics, for each of the imperatives. Therefore, the combined effect fosters the strengths and mitigates the weaknesses in the whole system.

Similarly, Sorenson and Sorensen (2001) show that franchised units provide better opportunities of learning through experimentation ("exploration"), while company owned outlets enhance the diffusion of such acquired knowledge, while enforcing standards (exploitation). To put it differently, both company owned units and franchised outlets would provide complementary benefits when it comes to knowledge creation and dissemination.

Therefore, since Bradach (1997), it has been widely accepted that part of the motivation driving the use of plural forms is that each individual organizational arrangement contributes to the efficiency of the other (Azevedo \& Silva, 2012b). And, indeed, this idea even underlied many of the previous and subsequent explanations. For instance, the rationale that companyowned stores signal the profitability of the business to the 'more efficient' franchisees (Gallini \& Lutz, 1992; Scott, 1995) implies that both modes of organization are complementary (Bradach, 1997; Sorenson \& Sorensen, 2001; Azevedo \& Silva, 2012b).

The second leading theoretical stream, in turn, is not as based on managerial arguments as the first, but on the economic concepts set forth by Agency Theory (Alchian \& Demsetz, 1972; Jensen \& Meckling, 1976). This approach assumes that one of the parties in a relationship detains more information on the transacted attributes than the other ${ }^{21}$. As a result, the informed party could act opportunistically (either by cheating or by making use of the additional information for its own best convenience) in pursuit of a larger share of the rents than that which would have been obtained with equally informed parties ${ }^{22}$. This is why, according to the Agency Theory, the mere possibility of strategic behavior based on

\footnotetext{
${ }^{20}$ Complementarities refer here to the synergies of having simultaneously two alternative modes of organization. See Milgrom and Roberts (1995) for a more detailed account.

${ }^{21}$ This defines asymmetric information (see Arrow, 1963).

${ }^{22}$ This behavior is frequently referred to as Moral Hazard (see Milgrom \& Roberts, 1992). In some situations, only the Agent can cheat (something called one-sided moral hazard), while in others, like in franchising, both the Agent and Principal can behave opportunistically (double-sided moral hazard).
} 
asymmetric information would require the establishment of monitoring and control mechanisms, as to induce parties to behave according to what had been initially agreed upon.

Under this perspective, franchisors would own some stores in order to monitor and control franchisees more effectively (Lafontaine, 1992). For instance, by doing itself, the franchisor has access to additional information on which he can rely to prevent franchisees from shirking (Martin, 1988). Chains can also wish to signal to their franchisees that the new "projects" they want to implement (for instance a new product, a new marketing campaign) are not only revenue-enhancing but are also generating new profits (Lewin-Solomons, 1999; Kranz \& Lewin-Solomons, 2008) $)^{23}$. They need to convince franchisees that their innovations are mutually beneficial. One way for the franchisor to credibly commit to select profit-enhancing innovations only is to own some stores.

Even if the Agency perspective has outnumbered the franchising contributions explicitly subscribing to the complementarities view (both in terms of the number of publications and of the citations received), it is this latter idea that underlies the benefits of combining alternative organizational arrangements in order to deal with monitoring and control issues. This is why, at the beginning of this section, we have argued that both of these theories are complementary.

Regardless of this aspect, there are other explanations to stable plural forms in franchising that by no means should be neglected, even if they that have not stood out as much as those mentioned before. This is the case, for instance, of the bargaining power argument, receiving a large number of citations over time, even though it only groups a small number of distinguished publications (see Table 2).

According to this perspective, the combination of company-owned and franchised units would provide the franchisor with additional bargaining power (Michael, 2000). First, ownership of some units provides franchisors with additional information (on the level of local demands, on the level of costs) mitigating asymmetric information. Second, partial integration also provides a credible threat to franchisees in the sense that it signals that the franchisor can

\footnotetext{
${ }^{23}$ The root of this commitment problem lies in the payment structure in franchise contract. Because it is difficult to contract on franchisees' costs, the franchise royalty is based on revenues alone. Given this structure, the chain would be tempted to promote innovations which are good for revenues even if the franchisees' profits suffer.
} 
operate units if required. Opportunistic franchisees know that, ultimately, franchisors can replace them (buying back the franchised units without experiencing too severe learning costs or terminating the contract and setting a company-owned unit in the local area). Even though this theory differs from the others previously mentioned, one can notice that the intuitions indirectly underlying this theory are not that far from the spirit of the works previously mentioned: both company owned stores and franchised units seem to be complementary in that the combination mitigates moral hazard and provides the chain with efficiency.

Table 7. Leading Plural Form explanations in franchising ${ }^{\mathrm{a}}$ and some well known papers subscribing to each of them

\begin{tabular}{|c|c|c|c|c|}
\hline Explanations & $\begin{array}{r}\text { Selected publications } \\
\text { Transitory }\end{array}$ & Citations $^{b}$ & Average $^{c}$ & Index $^{d}$ \\
\hline Resource & Oxenfeldt \& Kelly (1969) & 53 & 1,15 & \multirow{2}{*}{3,21} \\
\hline constraints & Caves \& Murphy (1976) & 205 & 5,26 & \\
\hline \multirow{2}{*}{$\begin{array}{l}\text { Ownership } \\
\text { redirection }\end{array}$} & Ozanne \& Hunt (1971) & $\mathrm{NA}^{e}$ & NA & \multirow{2}{*}{1,74} \\
\hline & Dant et al (1996) & 33 & 1,74 & \\
\hline \multirow{2}{*}{ Agency/ Signaling } & Gallini \& Lutz (1992) & 94 & 4,09 & \multirow{2}{*}{3,22} \\
\hline & $\operatorname{Scott}(1995)$ & 47 & 2,35 & \\
\hline \multicolumn{5}{|c|}{ Stable } \\
\hline \multirow{5}{*}{$\begin{array}{l}\text { Complementarities } \\
\text { /Synergies }\end{array}$} & Bradach $(1997,1998)$ & 183 & 10,17 & \multirow{5}{*}{4,31} \\
\hline & Bai \& Tao (2000) & 27 & 1,93 & \\
\hline & Sorenson \& Sorensen (2001) & 100 & 7,14 & \\
\hline & Cliquet \& Penard (2012) & 4 & 1,33 & \\
\hline & Meiseberg (2013) & 1 & 1,00 & \\
\hline \multirow{7}{*}{$\begin{array}{l}\text { Agency/Incentives/ } \\
\text { Signaling }\end{array}$} & Rubin (1978) & 315 & 8,51 & \multirow{7}{*}{7,22} \\
\hline & Brickley \& Dark (1987) & 336 & 12,00 & \\
\hline & Martin (1988) & 117 & 4,33 & \\
\hline & Norton (1988) & 181 & 6,70 & \\
\hline & Brickley; Dark \& Weisbach (1991) & 71 & 2,96 & \\
\hline & Lafontaine (1992) & 321 & 13,96 & \\
\hline & Agrawal \& Lal (1995) & 41 & 2,05 & \\
\hline Bargaining & Michael (2000) & 45 & 3,21 & 3,21 \\
\hline \multicolumn{5}{|c|}{$\begin{array}{l}\text { Notes: }{ }^{a} \text { The figures presented in this table are merely illustrative. Because some streams concentrate more recent } \\
\text { publications than others, a simple comparison of the number of citations is largely biased, even though it can } \\
\text { provide an intuition on the relevance of each theoretical stream. }{ }^{b} \text { Total number of citations. }{ }^{c} \text { Average number of } \\
\text { citations per year, since publication. }{ }^{d} \text { Average number of citations per year, since publication, divided by the } \\
\text { number of papers in the stream about which information is available. }{ }^{e} \text { No available data. Based on data retrieved } \\
\text { from the Isi Web of Science and Scopus platforms. }\end{array}$} \\
\hline
\end{tabular}

This being said, it is reasonable to conclude that even though the number of papers providing explanations for plural forms based on incentives, as well as their citations, have by far outnumbered those relying on other views (i.e.: complementarities and bargaining), it is the complementarities perspective that underlies the vast majority of the existing explanations. After all, as we have argued before, this latter theory underlies the incentives perspective and 
somehow, the bargaining idea as well. And therefore, it can be treated as the dominant explanation for the coexistence of company-owned and franchised units.

\subsection{Organization Theory and plural forms: a challenge?}

Further contemporary advances in this field have shown that the (stable) plural form phenomenon goes beyond the coexistence of company-owned and franchised units in the franchising sector. It in fact encompasses a wide range of transactions within organizations (Menard, 2013, 2014), both in the procurement of inputs (Carlton, 1979; Monteverde \& Teece, 1982; Parmigiani, 2007; Parmigiani \& Mitchells, 2009) and in the distribution of products (Dutta et al, 1995; Heide, 2003). This finding seems to hold across different sectors and distinct institutional and competitive environments; as we have argued in the introduction of this paper.

This implies that, despite the significant relevance that has been attributed to plural forms in franchising, they only tell us part of a larger story. This has led numerous scholars to search for broader explanations, either regarding different stages in the supply chain (the procurement of inputs, for instance) or addressing the distribution of distinct types of products and/or services, endowed with their own particular idiosyncrasies (namely in the marketing/distribution channels literature). Some of the most distinguished publications in this respect are shown in Table $3^{24}$.

\footnotetext{
${ }^{24}$ The figures presented in this table are merely illustrative. Because some streams concentrate more recent publications than others, a simple comparison of the number of citations is largely biased, even though it can provide an intuition on the relevance of each theoretical stream. Also note that these studies tend to be more recent than the ones presented in Table 1, and therefore, some of these publications have not yet accumulated a significant amount of citations.
} 
Table 8. Leading Plural Form explanations in other sectors and some well known papers subscribing to each of them

\begin{tabular}{lllcc}
\hline \multirow{2}{*}{ Explanation } & \multicolumn{1}{c}{ Selected publications } & Transaction & Citations $^{a}$ & Average $^{b}$ \\
& & & & \\
\hline Incentives/Agency & Heide (2003) & Downstream & 94 & 8,55 \\
\hline \multirow{2}{*}{ Complementarities } & Parmigiani \& Mitchell (2009) & Upstream & 48 & 9,60 \\
& Puranam et al (2013) & Upstream & 0 & 0,00 \\
\hline \multirow{2}{*}{ Bargaining } & Heide (1994) & Downstream & 607 & 30,35 \\
\multirow{2}{*}{ RBV } & Jacobides \& Hitt (2005) & Downstream & 63 & 7,00 \\
& Parmigiani (2007) & Upstream & 107 & 15,29 \\
& Ahmadjian \& Lincoln (2001) & Upstream & 86 & 6,62 \\
\hline \multirow{2}{*}{ TCE } & Dutta et al (1995) & Downstream & 75 & 3,95 \\
& Mols (2000) & Downstream & NA & NA \\
\hline
\end{tabular}

Notes: ${ }^{a}$ Total number of citations. ${ }^{b}$ Average number of citations per year, since publication. Based on data retrieved from the Isi Web of Science and Scopus platforms (2014).

Note, however, that despite the afore-mentioned efforts, many contributions have still provided overlapping explanations with those in the franchising literature. For instance, Heide (1994; 2003), respectively, focus on a bargaining perspective and on incentive issues; while Parmigiani and Mitchells (2009) and Puranam et al (2013) reinforce the argument in favor of the existence of complementarities in using plural forms.

This finding is not surprising. After all, even though franchising theory and other contemporary contributions regard different stages in the supply chain and/or distinct products, they still address the same 'anomaly' to organization theory: "why do actors often choose to address and combine alternative modes of organizations simultaneously?" (Menard, 2013, p.135). This evidences the fact that franchising theory only tells us part of the plural form story. This is why, at the same time, different scholars have sought for more general approaches to this issue, i.e.; those that are capable of explaining the existence of plural forms in any type of organization or any stage in the supply chain.

To this end, many have turned to the so-called "theories of the firm", roughly addressing what should be made within the organization and what should be bought; in order to provide a different explanation for the existence of plural forms. In this respect, there are two theoretical streams that have stood out: the Resource Based View ${ }^{25}$ (hereafter RBV) and the Transaction Cost Economics (TCE) perspective; even though none of them seems to have been, so far, very successful in this endeavor.

\footnotetext{
${ }^{25} \mathrm{We}$ also group under this label the Knowledge perspective and the capabilities view.
} 
The RBV, in its various manifestations, has become one of the most influential and cited theories in the strategy literature seeking to understand the origins of competitive advantage, i.e.: the reasons why some firms outperform others, even in highly competitive environments (Kraaijenbrink, Spender \& Groen, 2010). And the mainstream answer, according to this approach, is attributed to the ownership of superior (physical) resources and capabilities (knowledge); which should be Valuable, Rare, Inimitable and Non-substitutable - VRIN (Barney, 1991). This approach has also provided an interpretation to the firm boundaries, in that "[...] firms internally govern comparative capability and outsource access to capabilities where the firm is comparatively incompetent" (Argyres \& Zenger, 2008: 6). Nevertheless, more recent developments in this field have argued that competitive advantage would not necessarily result from owning superior resources, but from having access to them, even if they are beyond the boundaries of the individual firm (Dyer \& Singh, 1998). And it is precisely this more contemporaneous view that has allowed for the incorporation of the RBV into the plural form debate.

As mentioned before, according to this stream, a given task should be performed by the party that detains the superior resources and capabilities required for its successful completion. Therefore, plural forms should be expected in two different scenarios. First, when there are homogeneous resources and capabilities across firms and markets, both alternatives should yield a similar performance; and as a result, it does not matter much whether or not the task is internalized (Mols, Hansen \& Villadsen, 2012). Second, when there are superior capabilities in the market relative to those available inside the organization, firms could choose to both make and buy in order to absorb and develop those superior capacities (Mols, 2010). Conversely, in the opposite scenario, concurrent sourcing would aim to disseminate a firm's superior resources and capabilities to the more cost-efficient suppliers (Mols et al, 2012).

In a more recent study, Gillis, Combs and Ketchen (2013) have relied on empirical data on franchising to provide a RBV explanation for plural forms. They find that both company owned units and franchised outlets possess different strategic assets that leverage key organizational goals. Therefore, the extent to which chains would favor company owned or franchised outlets would depend on the degree to which each of the strategic resources 
contributes to the achievement of the organizational strategic goals and to the value maximization of these resources ${ }^{26}$.

To sum up, these ideas are tightly knitted with innovation motivations, either regarding its absorption or its dissemination. Furthermore, a crucial idea underlying these explanations is that the alternative organizational arrangements that compose the plural form are complementary, just like in the franchising case or in the explanations by Parmigiani and Mitchell (2009) and by Puranam et al (2013). Even though Parmigiani (2007) has found empirical support for this argumentation, one can realize that the RBV alone does not suffice to explain stable plural forms.

First, because capabilities and resources are likely to change over time, firms should not be indifferent about the organizational arrangement decision for long: at some point, they must eschew one type of organization in favor of the other. Second, the innovation argumentation contradicts the very essence of the "pure, mainstream RBV", in that it submits that both firms and suppliers would be willing to disseminate strategic, superior VRIN resources and capabilities. But if these are precisely the sources of competitive advantage, firms should, by no means, have strong incentives to do so.

Transaction Cost Economics (TCE), the second leading approach in recent studies on plural forms, has in turn been much more under scrutiny for being rather unable to provide an explanation for the plural form phenomenon in its mainstream formulation, than used for the purpose of generating novel ideas. The alignment principle stated before, suggests that, for a given level of asset specificity, firms should always be able to rank alternative organizational arrangements. To put it more sharply, we should not observe plural forms. For instance, Dutta et al (1995) have been the first to empirically test TCE predictions in plural forms. Even though they have found some support for these ideas, it should be remarked that it does not directly regard asset specificity per se, but approach the idea underlying the uncertainty concept.

A similar finding has been more recently published by Parmigiani (2007). Although she was unable to provide support for asset specificity predictions, when it comes to plural forms

\footnotetext{
${ }^{26}$ Once again, notice that the complementarities perspective underlies this idea.
} 
(namely, that higher asset specificity would lead to a larger integrated proportion), performance uncertainty has strongly complied with the TCE framework (intermediate levels of uncertainty lead to concurrent sourcing; and the higher the performance uncertainty, the larger the share made in-house). This latter variable has received much less academic attention than asset specificity; because as Williamson (1996) himself argues, it is the latter variable that provides the best predictive power (the "big locomotive" of the theory).

This being said, it seems like TCE does have something to tell about plural forms, even if it regards uncertainty rather than asset specificity itself ${ }^{27}$. In fact, in a recent survey of the Brazilian Agribusiness Sector, Menard et al (2014) have found that uncertainty, along with asset specificity; have played important roles in driving plural forms to be a preponderant mode of organization in these firms. And this could have crucial theoretical and empirical implications, being that TCE has strongly stood out in organization theory. But further developments in this respect are yet to come.

For the time being, what we can realize is that asset specificity and uncertainty, two key variables in the TCE framework, are somehow able to capture some of the ideas underlying both the RBV and the Agency perspectives for plural forms. First and perhaps more trivial of all, strategic resources are no different than specific investments, when these are translated into the RBV language (Foss, 2005). After all, the quasi rent attributable to valuable, rare, non-substitutable and non-transferable assets (tangible or intangible) should be equal to their ability of generating economic rents ${ }^{28}$. And assuming these are valuable, their quasi rent must be large.

Next, what we can realize by analyzing Table 4, summarizing our survey, is that different types of uncertainty appear in the main variables explored in all three theoretical perspectives for plural forms.

\footnotetext{
27 After all, according to the asset specificity reasoning, plural forms should be transitory, as previously explained.

${ }^{28}$ If these value-creating resources are non-transferable and non-substitutable, their alternative use should yield no value.
} 
Table 9. Summary of the literature

\begin{tabular}{|c|c|c|}
\hline Theories reviewed & Variables explored & Most illustrative papers \\
\hline Agency Theory & $\begin{array}{l}\text { Behavioral or performance } \\
\text { uncertainty. }\end{array}$ & Heide (2003) \\
\hline RBV & $\begin{array}{l}\text { Capabilities, knowledge }{ }^{a} \text {, } \\
\text { Technological uncertainty. }\end{array}$ & $\begin{array}{c}\text { Jacobides \& Hitt (2005) } \\
\text { Parmigiani (2007) } \\
\text { Mols (2010) } \\
\text { Mols et al (2012) } \\
\text { Gillis et al (2014) }\end{array}$ \\
\hline TCE & $\begin{array}{l}\text { Asset specificity, volume } \\
\text { uncertainty, performance } \\
\text { uncertainty, technological } \\
\text { uncertainty. }\end{array}$ & $\begin{array}{c}\text { Dutta et al (2005) } \\
\text { Parmigiani (2007) } \\
\text { Mols (2010) } \\
\text { Menard et al (2014) }\end{array}$ \\
\hline
\end{tabular}

Notes: ${ }^{\mathrm{a}}$ Includes routines, learning, and innovation processes.

Notice that the key variable in the Agency perspective is behavioral or performance uncertainty, given that the main problem here is the potential moral hazard brought by high monitoring and controlling costs. Hence, by using plural forms, firms are able to better monitor and control transacting parties and therefore, they can reduce behavioral uncertainty.

We can also see that uncertainty underlies the RBV explanation for plural forms, but in a rather different dimension, since behavioral issues are not a major concern here, as in Agency Theory. In this case, heterogeneous resources and capabilities cross firms may be interpreted as different technological abilities. This means that a given firm might master one or another technology and in different intensities. Therefore, choosing the best resources or capabilities to invest in is no different than being uncertain about technological choices, either because there is a wide variety available or because it evolves rapidly, calling for novel capabilities. And this is why technological uncertainty constitutes an important variable in the most illustrative papers seeking to explain plural forms by making use of the RBV.

Finally, needless saying, the most illustrative papers on plural forms that turn to a Transaction Cost Economics perspective make use of behavioral (or performance) uncertainty, volume uncertainty (or market uncertainty) and technological uncertainty (Parmigiani, 2007); and of course, asset specificity. After all, this is the only theory, among these three, to explicitly recognize uncertainty as a key variable in choosing organizational arrangements. And although Williamson (1985) himself is most explicitly concerned with behavioral and market uncertainties, contemporary authors like Parmigiani (2007) have broadened this view to include technological uncertainty. And as mentioned before, they have found support for the idea that it is not asset specificity per se that is able to explain plural forms, but uncertainty 
(Dutta et al, 1995) or, more recently, uncertainty and asset specificity (Parmigiani, 2007; Menard et al, 2014).

Finding that uncertainty underlies all three explanations for plural forms based on the theories of firm and that asset specificity captures the idea of both TCE and RBV is interesting because by combining them to predict plural forms, we can account for all existing explanations. Therefore, we propose the following:

$P_{1}$ : The combination of asset specificity with uncertainty pushes towards the adoption of plural forms.

\subsection{Concluding remarks and future directions}

In this paper, we have briefly presented the evolution of the theoretical contributions explaining why firms decide to use more than one organizational arrangement to govern similar, or even identical transactions. As we have argued, this constitutes a puzzle to the mainstream organization theories, all predicting the superiority of a single mode of organization over its alternatives, for each transaction.

The very first contributions in this respect, namely until the mid 90's, followed the mainstream view (i.e.: defend the superiority of one mode of organization over its alternatives) and treat plural forms as a transitory phenomenon. As we have stressed throughout this paper, the resource constraint and the ownership redirection theories provide conflicting predictions relative to the long-run prevailing structure (pure company owned vs. pure franchised). Transaction Cost Economics and the New Property Rights Perspective, in turn, predict the convergence to a single organizational arrangement, according to the transactional attributes and environments (either markets, hybrids or hierarchies); once the path dependent reliance on the less efficient concomitant organizational arrangement is over.

However, several empirical analyses, mostly from the franchising literature, rely on panel data to show the stability of the mix between company-owned and franchised units. These findings, as stressed before, have greatly modified the way by which managers and organization scientists treat and analyze plural forms. For instance, given the stability 
assumption, explanations based on the agency theory and on complementarities have emerged and dominated the related literature.

More recently, the coexistence of alternative modes of organization for similar transactions has been shown to go beyond the franchising context. Here again, many empirical papers stress its prevalence in various industrial sectors, both upstream and downstream. This has led scholars to seek for alternative explanations for this stylized fact; namely by making use of the so-called "theories of the firm" (especially TCE, PRT, RBV).

We saw that the mere existence, not to mention the stability of plural forms, is a real puzzle for the (still) dominant theories in the economics of organization, and in particular, TCE.

The traditional story based on asset specificity as the main driver of organizational choice cannot predict the emergence of plural forms. We would go too far if we conclude that the whole theory is invalidated. Indeed, recent works try to develop an efficiency explanation for plural forms as a way to mitigate transaction costs, thus keeping the main TCE reasoning. Furthermore, they usually combine asset specificity with other transactional attributes to generate new propositions (Parmigiani, 2007; Mols, 2010). Among these variables, uncertainty could be a relevant candidate in association with asset specificity.

This approach can have important implications according to several case studies on plural forms in the procurement of inputs by Brazilian Agribusiness firms (Menard et al, 2014). More specifically, three dimensions within the broader concept of uncertainty have shown to be quite relevant, in association with asset specificity: volume uncertainty, technological uncertainty and performance (or behavioral) uncertainty.

It is also quite interesting to note that these three dimensions of uncertainty can be suited into important aspects underlying all the three leading 'theories of the firm' explanations for plural forms that have been discussed throughout this paper: TCE, the RBV and the Agency Theory, as mentioned before.

Bearing in mind this concluding discussion and our proposition pointing towards the combination of asset specificity and uncertainty as potential explanatory variables for plural 
forms, important developments in this respect are yet to be made. And therefore, we will investigate in more details, in the following paper, this particular combination. 


\section{Chapter 3}

\section{Plural forms: a variety of organizational arrangements}

\subsection{Introduction}

In recent years, a lot of effort has been put into understanding the motivations pushing towards the consideration and examination of plural forms in a wide range of transactions within organizations (Menard, 2013, 2014), both in the procurement of inputs (Parmigiani \& Mitchell, 2009) and in the distribution of products (Heide, 2003); or even in the service sector (Nickerson \& Silverman, 2003; He \& Nickerson, 2006). Not to mention the extant franchising literature that inspired the above-mentioned contributions and that has been available since the 80's (Bradach \& Eccles, 1989; Lafontaine, 1992; Lafontaine \& Shaw, 2005).

Very little, however, has been specifically said about the composition and variety of the plural form. In fact, in a recent bibliographic survey conducted on the ISI Web of Science platform $^{29}$, only the paper by Puranam, Gulatti and Bhattacharya (2013) could be identified in an attempt to determine how much should be made and how much should be bought in the plural form. This is why Stump and Kim (2015:156) argue that there is a gap in the literature "[...] from the perspective of actual practice to discover what combinations are present and the relative intensity of the individual mechanisms that comprise these plural forms."

Therefore, in this paper, we seek to shed some light on the variety of plural forms; i.e. the diversity of the combinations of organizational arrangements composing the plural form. Therefore, we intend to provide an answer to the following question: What explains the diversity of plural forms?

Our concept of diversity includes all the possible combinations of organizational arrangements that are simultaneously used in order to obtain a given input. However, in order to keep our argumentation tractable, we group these combinations into three subsets, i.e.,

\footnotetext{
${ }^{29}$ For further details on this survey, refer to chapter 2.
} 
those involving different classes of organizational arrangements (make-and-buy, make-andally, buy-and-ally, make-buy-and-ally), those addressing multiple categories of hybrid arrangements (ally-and-ally), and finally, those dealing with a combination of the two groups mentioned above (make-ally-and-ally, buy-ally-and-ally, make-buy, ally-and-ally). We therefore push this understanding a step further than Krzeminska, Hoetker and Mellewigt (2013), as we analyze a broader set of combinations, beyond make-and-buy, make-and-ally, buy-and-ally. Moreover, in doing so, we stress that allying is not a uniform concept, but a diversified set of hybrid arrangements (Menard, 2004), each of which presenting its own peculiarities, even in the composition of the plural form.

Empirical findings on the sourcing of agricultural inputs in Brazil demonstrate the importance of such distinctions. For example, Minerva, a leading company in the Brazilian beef sector obtains $65 \%$ of its traced kettle by means of relational contracts, $25 \%$ through short-term formal contracts and the remaining 10\% via long-term formal contracts (Menard, Saes, Silva \& Raynaud, 2014). Delfi, an important player in the Brazilian cocoa industry, adopts a similar sourcing strategy: $45 \%$ of its cocoa beans come from relational contracts, $50 \%$ from long term formal contracts and $5 \%$ is obtained by means of medium term formal contracts (Menard et al, 2014). In different terms, these are cases of ally-ally-and-ally.

Similarly, Sao Manoel, producing $0.5 \%$ of the entire Brazilian sugar production, obtains $75 \%$ of its sugar-cane on its own farms, $5 \%$ by means of relational contracts and $20 \%$ by turning to formal contracts (Menard et al, 2014). Klabin, one of the leading players in the Brazilian pulp and cellulose sector obtains its inputs in a very similar manner: $80 \%$ of its cellulose comes from its own trees, $14 \%$ is obtained with relational contracts and $6 \%$ by means of long term contracts (Menard, 2014). These two examples are cases of make-ally-and-ally (for a more comprehensive set of examples of the multiple combinations, refer to Menard et al, 2014, chapter 16)

In order to understand the motivations underlying this wide variety of plural forms, we first take a step back and build a theoretical model to predict when plural forms should or should not be observed. In doing so, we follow Parmigiani (2007), Krzeminska (2008) and Menard $(2013,2014)$ to propose an integrative model of asset specificity and uncertainty to predict 
plural forms and their variety. Our model extends existing literature in that it allows for predictions rather than explanations for the existence or not of plural forms.

Next, given the predictions shown in our model, we build some theoretical hypotheses to clarify the variety of plural forms. In particular, we associate multiple types of uncertainties (namely, market, technological and performance assessment) to the three sets of plural forms previously defined, keeping constant the degree of asset specificity.

Our hypotheses predict the circumstances under which each type of plural forms should emerge and be efficient; and therefore, they might assist decision-makers in deciding what combination of organizational arrangements better suits the conditions under which they operate. This might help explain why some transactions are carried out by using one or another combination, or even clarify why different companies, operating in the same sector and institutional environment, use different combinations of organizational arrangements to govern their transactions.

\subsection{Asset specificity and uncertainty motivate plural forms}

In the past few years, a great number of contributions have attempted to provide theoretical explanations for the existence of (stable) plural forms ${ }^{30}$. Part of this phenomenon can be attributed to the difficulty of Transaction Cost Economics (TCE) in predicting a recurrent empirical finding in that firms often combine alternative organizational arrangements to organize similar (identical) transactions.

This means that, for a given firm in a given institutional environment, transactions endowed with the same attributes (asset specificity, frequency and uncertainty) are governed simultaneously by different organizational arrangements (e.g.: spot market and hierarchy or hybrids and spot market). Moreover, such finding has been shown to persist over time ${ }^{31}$, and has been found in a wide variety of organizations, both upstream and downstream, and across multiple economic sectors and institutional environments (see chapter 3 for further details).

\footnotetext{
${ }^{30}$ See chapter 2 and Schnaider, Raynaud \& Saes (2014) for a detailed description of these explanations.

${ }^{31}$ See for instance, Lafontaine and Shaw (2005) in the franchising context.
} 
Nevertheless, according to the now dominant literature in TCE (Williamson, 1985, 1996, 2000), such empirical findings should not been predicted, since they challenge the discriminating alignment hypothesis (especially with regard to asset specificity, which presents the greatest predictive power).

Said differently, according to TCE, transactions presenting the same attributes (specially asset specificity), within the same institutional environment, should be organized identically by means of a single organizational arrangement. This is why TCE has frequently been under scrutiny for having difficulties to explain and predict plural forms.

Despite this fact, latter contributions (Dutta, Bergen \& Heide, 1995; Parmigiani, 2007) have indicated that there could indeed be room for plural forms in the TCE framework. Nonetheless, it is uncertainty, rather than asset specificity per se, that could help explain these empirical findings. In line with Duta et al (1995) and Parmigiani (2007), other contemporary scholars have shown that uncertainty constitutes an important explanatory variable for plural forms, although other theoretical streams have been used to this end. For instance, Heide (2003) relied on agency theory, while Mols, Hansen and Villadsen (2012) made use of the Resource Based View of the firm to show that uncertainty matters to the understanding of plural forms.

Further developments in TCE followed these views only in recent years, suggesting that the interactive effects between asset specificity and uncertainty would explain the existence and stability of plural forms (Krzeminska, 2008; Menard, 2013, 2014). Still, neither of these scholars has shown how the interaction of these variables would shape the composition of the plural form. Rather, they have stressed that such interaction matters and that this could help explain plural forms within the TCE framework. And this constitutes already an important advance in the understanding of this 'anomaly'.

Interestingly, these contributions are consistent with Williamson (1985: 60), as he clearly submits that "[...] the interaction effects between uncertainty and asset specificity are important to an understanding of economic organization”. And although neither does he develop this idea much further (indeed, there is a very narrow discussion on this matter in Williamson (1991)) nor does he mention plural forms in any way, the mere recognition that 
the interactive effects of these two variables matters makes room for the contributions mentioned before and for an understanding of plural forms within this framework.

Therefore, in the subsequent sections, we follow Williamson (1991), Parmigiani (2007), Krzeminska (2008), Mols (2010) and Menard (2013, 2014) and propose an integrative model of asset specificity and uncertainty to expand these contributions. By doing so, not only do we provide an understanding to why plural forms exist or to when they should or should not be observed; but we also push further into the clarification of the variety of plural form manifestations.

\subsubsection{The integrative model}

Our starting point is a simple scheme relating the governance decision to both asset specificity and uncertainty. This is depicted in

Figure 4, below. In the discussion presented next, we will provide explanations as to: i. why we have chosen to represent the curve as such; ii. what arrangements can be found in the grey zone and when they should be expected; and finally, iii. what happens outside the grey zone and why.

Figure 4. An integrative model.

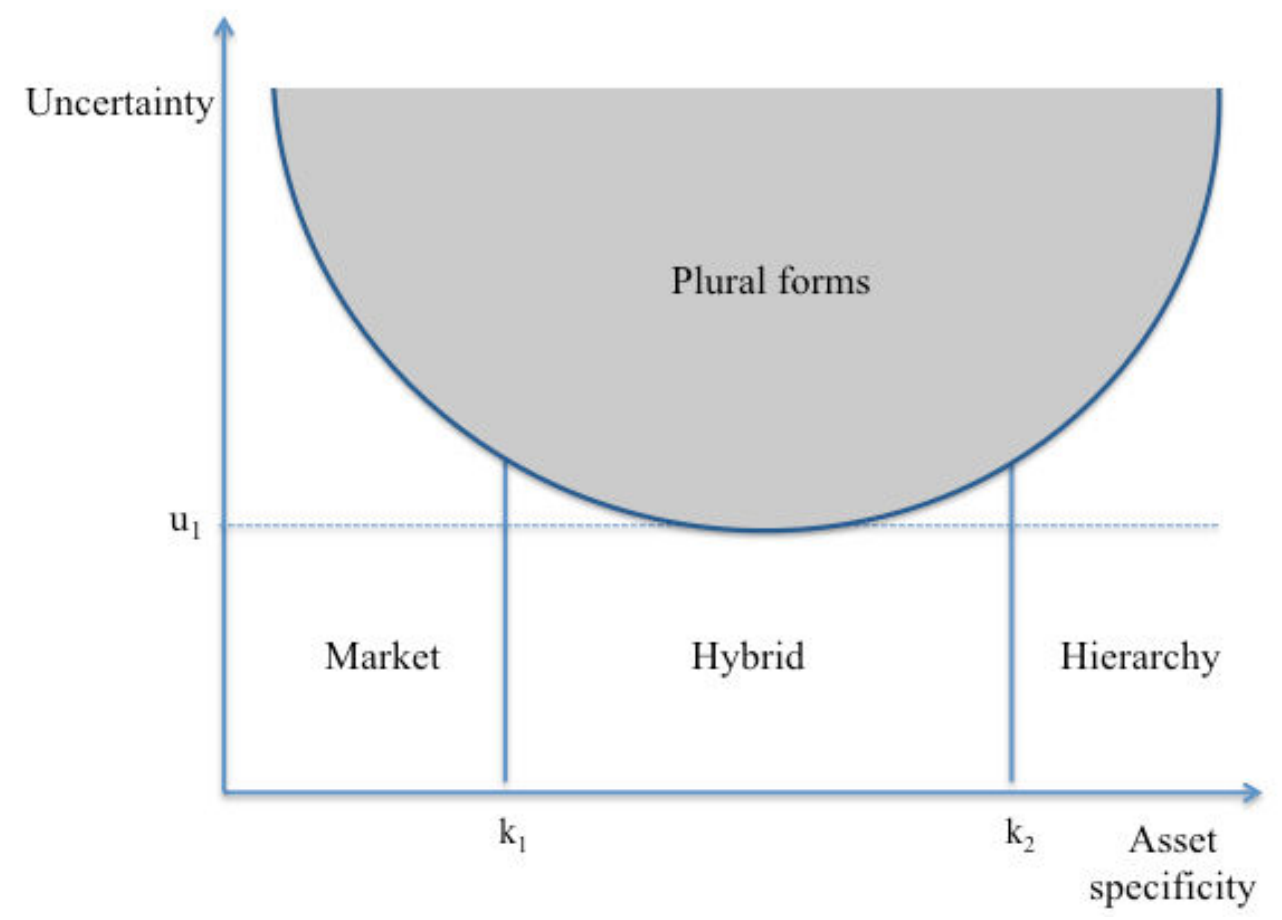


The basic idea of our scheme is quite intuitive. First, for simplicity, take only the horizontal axis (asset specificity). i.e., assume uncertainty to be zero. In this case, the mainstream Transaction Cost Economics (TCE) prediction is that the market would best economize on transaction costs if the level of asset specificity is smaller than $k_{1}$. If the level of asset specificity falls between $k_{1}$ and $k_{2}$, hybrids would be the efficient solution. Finally, for specific investments where $\mathrm{k}>\mathrm{k}_{2}$, hierarchy would be best.

However, once we introduce high external uncertainty (other than opportunism- behavioral assumption) to this analysis, the efficient solution might shift from the "pure range" (the region below the grey zone) to the "plural range" (the grey zone) if uncertainty is at least higher than $\mathrm{u}_{1}$. Indeed, Williamson (1991) himself assumes uncertainty to be relevant in some degree, and this is why we predict pure forms even when there is some uncertainty. Our point is merely that there would be a threshold level beyond which plural forms would be best and this threshold level would depend, among other things, on asset specificity.

A very similar idea has been partially confirmed by Krzeminska (2008), who has found that companies both made and bought if asset specificity were at least much larger than $\mathrm{k}_{1}$ and uncertainty were higher than the constant threshold level defined in her study ( $u_{1}$ in our case). However, her linear model does not allow for predictions for $\mathrm{k}<\mathrm{k}_{1}$ (indeed, she explicitly captions such region with a question mark - see Krzeminska, 2008: 176) nor does it seem to be very realistic for $\mathrm{k}>\mathrm{k}_{2}$, given that it would be reasonable to assume that when investments are transaction specific to non-trivial degrees (or even dedicated), higher and higher uncertainty becomes required in order for any organizational mode to be preferred to vertical integration (because of transaction costs).

Also, it is worth mentioning that Krzeminska (2008) has chosen to address only the make and buy problem, which, despite its relevance, does not tell adequately the entire plural form story. Therefore, a more general model would require additional considerations and even a differently shaped curve.

Hence, we are proposing a substantially revised version of her model by introducing a $U$ shaped curve, as depicted in 
Figure $4^{32}$. This particular innovation better reflects the original insights by Williamson (1985), in that when there are no specific investments to be made, the market should prove to be the efficient solution; and when there are very specific investments, hierarchy should prove the only efficient outcome. But what matters most for our topic here is what happens when neither conditions are fully satisfied.

This is because as we move from $\mathrm{k}_{1}$ to zero (i.e. to the left), the level of uncertainty that is required in order to shift the organizational decision from pure market arrangements to the plural form region needs to be increasingly high. To put it differently, as $\mathrm{k}$ diminishes and gets closer to zero, uncertainty must grow a lot more than accordingly (or even approach infinity) in order for plural forms to outperform the spot market (which best economizes on transaction costs at that level of asset specificity). Nonetheless, if the degree of asset specificity is zero or very close to it, the spot market in its pure manifestation will always be the most efficient governance solution, regardless of the uncertainty affecting this transaction.

Such idea is consistent with Williamson (1985: 59), as he clearly emphasizes that "[...] uncertainty is a matter of little consequence for transactions that are non-specific" because new trading relations can be easily arranged. Therefore, given this non-specificity, “[...] market exchange continues [...], whatever the degree of uncertainty" affecting such transaction (Williamson, 1985: 59).

Indeed, this is the reason we propose that for $\mathrm{k}=0$ or close to it, the spot market should outperform any organizational mode. Moreover, as mentioned before, this idea underlies the rationale that increasingly high levels of uncertainty become required in order to shift the governance of transactions that are specific to very low degrees from market arrangements to plural forms, i.e., the region defined on the inside of the $U$ shaped curve shown in

Figure 4. The basic notion here is that as investments become less specific, transacting parties can be more easily replaced in the event of a disturbance and therefore, uncertainty becomes increasingly less relevant (or, to put it differently, increasingly higher levels of uncertainty become required in order to shift the arrangement from the spot market to the plural form region).

\footnotetext{
${ }^{32}$ We root our discussion in the $U$ shaped curve, although other shapes might also reflect the same idea, such as a "V" shape or even a "kinked U". Therefore, for simplicity and to keep our scheme more general, we will assume these cases to be particular situations of our $U$ shaped curve. In fact, as we will latter argue, it suffices that the curve increases in the extremes (very low or very high asset specificity).
} 
Conversely, as the level of $\mathrm{k}$ rises beyond $\mathrm{k}_{2}$ (i.e. to the right), the potential for opportunistic behavior (and quasi-rent holdup) increases such that hierarchy should be more and more preferable to other options. Being such, in order for plural forms to outperform it, an increasingly higher degree of uncertainty is needed to justify a shift from vertical integration to plural forms. In extreme cases, where assets are idiosyncratic (or dedicated), vertical integration should prove to be the only governance solution, regardless of the degree to which uncertainty is present.

Once again, this is consistent with Williamson (1985:60), in that "[w]henever assets are specific in nontrivial degree, increasing the degree of uncertainty makes it more imperative that parties devise a machinery to "work things out"'. And although he does not explicitly, at this specific point, argue that such "machinery to work things out" would necessarily consist of the hierarchical organizational arrangement, the mere statement that this would become necessary because "[...]contractual gaps will be larger and the occasions for sequential adaptations will increase in number and in importance as uncertainty increases" (Williamson, 1985: 60) suggests that vertical integration should prove to be the best solution for highly specific assets, regardless of the degree to which uncertainty is present.

Note that by no means do we intend to undermine the relevance of uncertainty when transaction specific investments are extremely high. Our point is merely that the best, efficient, organizational arrangement to deal with such situation should always be the hierarchical mode because of the possibility of the opportunistic holdup of appropriable quasirents.

However, between these two polar cases, conditional to a certain degree of asset specificity (between $k_{1}$ and $k_{2}$ or close to these areas, either from the left or from the right) and to uncertainty above a certain threshold $\left(\mathrm{u}_{1}\right.$, under which uncertainty would not be enough to influence organizational choice), various modalities of plural forms would develop. This is because they would better help agents in dealing with uncertainty, at these given levels of asset specificity.

The idea is similar to that in Williamson (1991), when he briefly discusses the interaction effects between uncertainty and asset specificity. In this respect, he argues that whereas the 
efficiency of all (pure) organizational arrangements is diminished with high uncertainty, that of hybrid arrangements is by far more susceptible to deteriorate. Thus, he submits that these arrangements are disfavored by high levels of uncertainty, even when specific investments are at in intermediate level, because they do not allow for the unilateral adaptations that are required in order to make things work in the event of a disturbance. Rather, they require responses which might be costly to obtain. In these cases, as Williamson (1991) argues, firms should turn either to markets or to hierarchies, which provide the required adaptations by means of unilateral responses or by fiat power, respectively (for further details see Williamson (1991).

However, as we will later argue, there could be cases where fiat power is not enough to guarantee efficiency under highly uncertain conditions, because the type of responses and adaptations that are needed can be best obtained in outsourced partners. For instance, when the source of disturbances originates inside the firm (e.g.: in behavioral issues involving the agents composing the organization), vertical integration might not be an efficient solution. This is similar to the idea developed in Alchian and Demsetz (1972), since the difficulty in measuring team production could undermine the efficiency of fiat power (Coff, 1999). Moreover, we submit that there could be less costly ways to obtain the necessary adaptations than turning to vertical integration. By combining different organizational arrangements, agents might easily adapt and enforce one or another arrangement.

Conversely, when the sources of disturbances originate on the market, not always do they provide the most efficient response. This could be the case where the quality of specific investments cannot easily be assessed, making room for opportunistic behavior instead of efficient responses. Therefore, by combining different classes of structures, agents can enforce these relationships by a number of ways, as we will argue in the following sections of this paper. For the time being, it suffices to make our point that under high uncertainty (above $\mathrm{u}_{1}$ ) and between $\mathrm{k}_{1}$ and $\mathrm{k}_{2}$ or close to them either from the left or from the right, various modalities of plural forms would develop as more efficient solutions.

One consequence of this modeling is that $\mathrm{u}_{1}$ (the threshold - or the minimum point in our curve) falls within hybrids; indicating that the decision for this type of organizational arrangement would be more likely to be converted into that for plural forms. After all, less uncertainty would be required in order to shift the organizational arrangement from hybrids to 
plural forms. And this is consistent with Williamson (1991), because, as we have already mentioned, he submits that hybrid arrangements would be more likely to deteriorate under high uncertainty.

Moreover, one can realize that both plural forms and hybrids mix the characteristics of different organizational arrangements, albeit in distinct ways. While hybrids typically combine 'white' in markets and 'black' in hierarchies to form a uniform shade of grey; plural forms use both 'white' and 'black' because under certain circumstances, both white and black are needed in order to guarantee efficiency (Lewin-Solomons, 1998). In different terms, plural forms could somehow be regarded as an extension to hybrids (or "hybrid arrangements [...] of a very special type" (Menard et al, 2014, p. 262) when uncertainty reaches non-trivial degrees.

In the next sections, thus, we will discuss under which circumstances (given the level of asset specificity and under different levels and types of uncertainty) and why each type of combination of 'white' and 'black' provides firms with greater efficiency.

\subsection{Understanding the variety}

From this section onward, we will leave out the cases where the level of uncertainty is below $\mathrm{u}_{1}$; i.e. the cases where pure forms should be observed. Therefore, we will solely address those cases for which the optimal decision should fall within the grey zone shown in Figure 4, that is: when uncertainty is above a certain threshold (and asset specificity within a delineated domain).

More precisely, we will focus on two aspects. First, we will show that there is a lot of heterogeneity in the grey zone identified in

Figure 4. Therefore, we will make an effort to classify and clarify this wide variety of plural forms. Second, we will stress that uncertainty is not a uniform and constant label, but rather, a concept that might be segmented into different dimensions. Therefore, with reference to some existing contributions, we will provide a classification for uncertainty.

To this end, we will first present some definitions and clarifications, particularly with respect to various types of uncertainty, which are essential for our model. Next, we rely on existing 
literature and build some hypotheses relating these various types of uncertainty to the composition of the plural form, thus providing an answer to our research question.

\subsubsection{Some crucial definitions}

\subsubsection{Types of uncertainty}

Uncertainty might be defined in many different ways. The very first formal definition has been provided by Frank Knight (1921), when he established the now classical distinction between uncertainty and risk: “[...] the term 'uncertainty' [refers] to cases of the nonquantitative type [of uncertainty]" (Knight, 1921: 19-20). This conception has been further developed in subsequent works, encompassing many distinct contexts and applications.

For instance, Dutta, Bergen, Heide and John (1995) have used the term 'uncertainty' to designate information asymmetry such that it becomes hard to determine how a good will be produced and/or its quality assessed (Barzel, 1982). Harrigan (1983) refers to the fluctuations in demand as uncertainty; while Williamson (1985) treats exogenous fluctuations in transactional conditions and behavioral issues as uncertainty.

Having this wide variety of definitions in mind, we have followed the more recent literature (Parmigiani, 2007; Menard, 2013) and segmented uncertainty into 3 concepts:

a. Market uncertainty: Uncertainty about the fluctuations of supply and demand (Robertson \& Gatignon, 1998). These fluctuations could be either in price and/or in quantity. "This uncertainty refers to unpredictability of demand [and/or supply] and an accompanying inability to accurately forecast and schedule production" (Parmigiani, 2007: 290). This conception is somehow similar to the concept of ambiguity developed in Menard $(2013 ; 2014)$, in that the difficulty in predicting supply and demand is a key variable.

b. Technological uncertainty: Refers to the probability of improvements in technology, rendering the current ones obsolete (Robertson \& Gatignon, 1998: 519). This conception incudes both technological volatility (rapidly evolving technologies) and variety (different technological possibilities, such that it is hard to determine at the 
outset the best one). This rationale, especially the latter one, is similar to the concept of complexity (Menard, 2013, 2014), in that agents are uncertain about the benefits brought by one or another technology.

c. Performance assessment uncertainty: "[...] concerns the difficulty of observing and measuring the adherence of the transacting parties to the contractual arrangements and the difficulty of measuring the performance of these parties" (Robertson \& Gatignon, 1998: 520). The basic notion here is that the harder it is to measure performance, the higher the risk of opportunism among parties (Barzel, 1982).

\subsubsection{Types of plural forms}

Plural forms may be constituted in a wide variety of ways. Perhaps the most well-known combination is the make-and-buy type which is so prevalent in franchising, for instance (Lafontaine \& Shaw, 2005). Although such label might suggest the combination of the spot market with some internal production; other possibilities might also arise.

For instance, firms might both produce internally and contract for the supply of a given input. They may also combine their internal production with both acquisitions on the spot market and through contracts. Going beyond this combination, firms might even produce and contract for the acquisition of inputs by means of different types of contracts.

The above-mentioned example illustrates a potential classification of the so-called plural forms in three ways:

a. Between pure forms: in this case, firms combine different classes of organizational arrangements (spot market, hybrids and hierarchy). This is the case, for example, of the "mainstream make-and-buy", where firms combine the spot market with some internal production. We will refer to this typology as the 'between' type of plural forms.

b. Within hybrid forms: in this case, firms combine different modalities that are typical of hybrid arrangements (ally-and-ally). For instance, firms acquire a given input, at the same time, through relational contracts and long-term formal contracts. We will refer to this typology as the 'within' type of plural forms. 
c. 'Combo' forms: in this case, firms combine (a) and (b) (make-ally-and-ally, buy-allyand-ally or make-ally-ally-and-buy). This is the case, for instance, when a firm at the same time acquires a given raw material on the spot market, but also contracts for part of this procurement by means of relational and long-term contracts and even, in some extreme cases, produces also some of the required input in-house. We will refer to this typology as the 'combo' type of plural forms.

\subsubsection{Hypotheses}

As already emphasized in our chapter 2, previous contributions have indicated that uncertainty, in association with asset specificity, plays an important role in pushing firms towards adopting plural forms (Parmigiani, 2007; Krzeminska, 2008; Menard, 2003). And although some have qualified uncertainty in terms very close to our own classification (Menard, 2014; Parmigiani, 2007); they have almost exclusively used this typology to verify whether or not they were important determinants of plural forms, in a general way. Said differently, almost no effort has been made in these contributions to relate the plural governance composition to the type of uncertainty the transaction is subject to. And it is precisely this correlation that we want to establish in the rest of this chapter.

To this end, we go back to the leading approach in TCE and bibliographically survey some well-known empirical papers (Mahoney, 1992). Interestingly, we are able to verify that firms use different organizational arrangements, according to how uncertainty has been defined and treated in each of these contributions ${ }^{33}$. For instance, more vertical integration has been found when firms are faced with high demand uncertainty (John \& Weitz, 1988; Levy, 1985; Macmillan, Hambrick \& Pennings, 1986; Robertson \& Gatignon, 1998; Russo, 1992; Walker \& Weber, 1984, 1987) or with high behavioral uncertainty (Anderson, 1985; Anderson \& Schmittlein, 1984; John \& Weitz, 1988; Robertson \& Gatignon, 1998). However, when technological uncertainty is high, firms would rather use the market (or turn to hybrid arrangements) than vertically integrate this given transaction. (Balakrishnan \& Wernerfelt, 1986; Harrigan, 1986; Robertson \& Gatignon, 1998).

\footnotetext{
${ }^{33}$ We do not intend to discuss the controversial results of these empirical papers, but rather, present their findings to make our point. In fact, most of these papers have failed to analyze asset specificity along with uncertainty, therefore presenting ambiguous results (see already Shelanski \& Klein, 1995).
} 
These findings indicate that the type of uncertainty the transaction is subject to might influence the governance decision, and in particular, the degree of vertical integration (or similarly, of commitment of the parties) in the transaction. We rely on this idea and expand it to the plural form context, along with the fact that many previous contributions on plural forms have segmented the concept of uncertainty, to build our first hypothesis:

$H_{1}$ : There is a correlation between the type of uncertainty that affects a transaction (or a family of similar transactions) and the type of plural form adopted to deal with this transaction.

Thus, if uncertainty plays a similar role in determining the degree of vertical integration in plural forms and in pure forms (see the discussion above on the empirical results in the latter case), we should expect to find different combinations of plural forms, depending on the type of uncertainty affecting the transaction (or family of similar/identical transactions).

This is why a discussion on the expected relationships between each type of uncertainty and the resulting typologies of plural forms becomes interesting. Thus, in the next subsections, we present such discussion.

\subsubsection{Market uncertainty}

In order to build hypotheses on the relationship between market uncertainty and the expected type of plural forms, first assume asset specificity to be very low and market uncertainty to be non-trivial.

In this case, firms would be, according to the leading view in TCE, acquiring inputs on the spot market; but at the same time, they would be uncertain about the volatility of the quantities/prices customers would be willing to buy/pay for the product(s) using those inputs or even on the quantities/prices on the market for those inputs.

Considering this situation, the best thing to do would be to vertically integrate a small part of the needs for this given input, so that the firm will be able to meet demand if it should require additional unexpected units/ or even be protected from its suppliers not delivering the quantity that had been agreed upon due to exogenous unforeseen contingencies (other than 
opportunism). Said differently, by both buying and internally producing the same inputs, firms may more easily adapt to high market volatility, both on the demand side and on the market for inputs. This scenario becomes particularly relevant when not having the product on time is more costly than having the product at a potentially higher cost.

Now, suppose that asset specificity is very high and that market volatility is also non-trivial; therefore requiring high adaptability. What would then be the best organizational solution, given that highly specific investments are at stake? In this case, firms could outsource a small part of the needs for this given input, so as to remain flexible, at the same time as the specific investments are secured by the vertically integrated component.

Of course, as we have argued before, these are extreme cases where uncertainty must be excessively high in order for any organizational solution to outperform the pure (or polar) cases described in the TCE literature, that is, the market or hierarchy. In fact, what matters most to our study are all the in-between cases, i.e., where asset specificity is neither zero nor dedicated, but rather, intermediate.

Nevertheless, our intention with these extreme cases was merely that of illustrating our point that by combining different classes of organizational arrangements, firms might both adapt more easily and protect specific investments when market uncertainty is high. This is why we hypothesize that:

$H_{1 a}$ : High market volatility (on the demand side or on the supply of inputs) pushes towards the adoption of the 'between' type of plural forms.

The situation described above can very often be verified in agribusiness firms; where site and temporal asset specificity are generally quite significant (there are particular cases where other types of asset specificity might also be relevant, such as when the product at stake is not a commodity but a differentiated variation of the product. Organics could very much exemplify this latter statement).

Moreover, it is known that agricultural products are sensitive to climatic volatility, such that too much/little rain might ruin the entire production (lettuce is as example of such case); or too high/low temperatures might significantly damage the harvest (orange is an example of 
such case). To make things worse, these climatic variations might even induce volatility in the demand for these products, such that it reaches its peak when production is in its lowest levels.

Said differently, agribusiness firms are quite often faced with some asset specificity and with significant market uncertainty; requiring them to safeguard against supply and demand volatility, while remaining highly adaptable and protecting specific investments. Many of these companies turn to plural forms of organization to this end. Examples about Brazilian agribusiness sectors provided in Menard et al (2014, see chapters 4, 5, 7 and 8) are consistent with this.

\subsubsection{Technological uncertainty}

Technological uncertainty might also play its role in determining the composition of plural forms. And as we have argued before, this could be either because companies are uncertain about the best technology (variety) or because technology is rapidly evolving and therefore, current investments might rapidly become obsolete (volatility).

Having this definition in mind, suppose that when a company invests in a given technology, it sets a given level of asset specificity, so that specific investments are fixed. For simplicity, assume first that this investment is highly specific, and therefore, that this technology is integrated into the company's hierarchy.

Now, suppose that after having invested, company managers fear that this might not have been the best choice, i.e., that alternative technologies might prove to be better. Said differently, assume that technological variety is non-trivial. What should decision-makers do, given that a specific investment has already been made? According to the scheme presented in Figure 4, they should shift the governance mode from pure vertical integration to plural forms.

In this case, the sole way of doing this would be to buy some inputs/products produced with the alternative technology from outside suppliers, such that it can gain information as to which technology is better. This is because by doing so managers are able to benchmark the quality of the inputs/products produced by the different technologies. 
Another possibility is that after having invested in a given technology and vertically integrated it, company managers believe that new alternatives may come up and render the current one obsolete (high technological volatility). Once again, they shift to plural forms by acquiring part of the needs for the inputs and products resulting from this technology from outside suppliers. This allows them to become aware of new technological developments and to gain capabilities to operate under these emerging technologies.

These scenarios illustrate companies that combine different classes of organizational arrangements in order to be protected from both technological variety and volatility, when specific investments are high. And what they do is precisely monitor the market for new technologies and absorb new capabilities form outside suppliers.

In turn, assume now that the technological choice is an industry-wide standard involving very low degrees of asset specificity. In this case, the mainstream solution should be to buy inputs and products produced by such technology from outside suppliers. However, suppose that company managers perceive technological volatility to be quite significant, such that alternative solutions might appear at any time. In this case, they combine their purchases with some vertical integration, such that they are able to develop in-house new capabilities that might at some point be disseminated to the industry, if it proves advantageous and is in the interests of this pioneer firm.

This might happen, for instance, when a given firm desires to launch a new product and, to this end, it needs to conduct some experimentation either on the new production techniques (supply side) or on the consumers' reactions in a controlled environment (demand side). And this process would go on for as long as innovation is required (i.e., once a given product is launched, the cycle continues with another new product).

Another example that illustrates well this idea is that of companies that integrate part of their needs for a given input in order to develop new, more efficient, production techniques. In the long-run, these productivity gains could be disseminated to suppliers because they are more cost-efficient than the firm itself (for instance, because of scale economies); while the firm keeps its internal production in order to maintain the innovative process. Just like in the 
preceding example, this process would go on as long as new developments are important to the firm (i.e.; it is not an ad-hoc situation).

To summarize, these examples illustrate that the combination of different classes of organizational arrangements helps firms in dealing with high technological uncertainty, even when specific investments are low. This is why we hypothesize that:

$H_{l b}$ : Technological uncertainty pushes towards the adoption of the 'between' type of plural forms.

Of course, all the cases discussed above, involving very high or very low asset specificity, are extreme examples that merely illustrate our point. In fact, as we have argued before, what matters most to our study is the collection of cases where technological investments are neither too specific nor non-specific at all; but rather, intermediate. But we shall argue that our reasoning still holds.

After all, the advantages brought by combining different classes of organizational arrangements in order to be protected from technological uncertainty are consistent with some of the explanations for plural forms, arising from the strategy literature (for further details, refer to Mols, 2010 and Mols, Hans and Villadsen, 2012). As discussed in chapter 2, firms would combine alternative modes of organization in order to absorb or disseminate capabilities from outside suppliers. And this is exactly the point we make when we propose that plural forms allow managers to become aware of new technologies and to verify the best available technological choice; i.e., to develop and maintain absorptive capacity (Cohen \& Levinthal, 1990).

A real-world example of such reasoning is the footwear industry in Brazil. Manufacturers often combine different classes of organizational arrangements in order to be aware of new technological developments that might arise, especially in leather production techniques (for further information, see Menard et al, 2014, chapter 12). 


\subsubsection{Performance assessment uncertainty}

"[...] the difficulty of observing and measuring the adherence of the transacting parties to the contractual arrangements and the difficulty of measuring the performance of these parties" (Robertson \& Gatignon, 1998: 520) might also shape the composition of the plural form. As mentioned before in this paper, the basic notion is that the harder it is to measure performance, the more room there is for agents to behave opportunistically (Barzel, 1982).

This is consistent with mainstream TCE (Klein, Crawford \& Alchian, 1978; Williamson, 1985), according to which the more specific are the investments in the transaction at stake, the more opportunistic agents may potentially be, making contractual safeguards so hard to establish that firms vertically integrate such transaction. Conversely, if there are no specific investments to be made and performance is easy to assess, market relationships would suffice to guarantee transaction's efficiency (see Zylbersztajn (2008) for a richer discussion on this matter). These cases are represented by the lines 2 and 4 in Table 10, shown at the end of this section.

However, the above-mentioned scenarios become true when only external performance assessment difficulties are at stake. Said differently, firms will vertically integrate when external performance is hard to assess. However, there could also be the case where internal performance is hard to assess (Alchian \& Demsetz, 1972). To put it more sharply, there are cases for which fiat power is not enough to guarantee efficiency.

In these cases, moral hazard becomes favored by those internal performance assessment difficulties, requiring firms to establish the right internal incentive system Holmström and Milgrom (1991). In fact, this issue has been extensively discussed in agency theory (Jensen \& Meckling, 1976) and is one of the most frequent explanations for the existence of plural forms in franchising (see chapter 2 for further details).

After all, if asset specificity is high (brand specificity in the case of franchising), but it is hard to assess internal performance, vertical integration fails to provide an efficient solution (for instance, it could be hard to monitor employees' performance when the chain expands). This is why, if we went back to our 
Figure 4, this particularly interesting situation would appear on the right side of $k_{2}$ and a lot above $\mathrm{u}_{1}$. To put it differently, it would be represented in the very right side of the grey zone. This would provide additional insights in favor of the use of plural forms to deal with this situation.

The basic idea here is that when asset specificity is high but internal performance assessment is hard, part of the production would be bought from outside suppliers (either by means of hybrid forms or on the spot market) in order to protect specific assets (brand in the franchising case); but at the same time, benchmark performance (external franchisees are generally considered more efficient than company managers in franchising literature because of highpowered incentives). This case is represented in line 1 in Table 10, shown at the end of this section.

But, quite often, there is a combination of both internal and external performance assessment difficulties. For instance, in the case of franchising, it could be hard to internally assess employees' performance and/or productivity; or even prevent them from shirking. But, at the same time, it may also not be trivial to verify whether (external) franchisees are complying with the quality standards established by the franchisor. This is why franchised chains combine company-owned and franchised outlets: they can monitor and benchmark both internal and external performance (this is represented in line 3 in Table 10, shown at the end of this section).

Now, what should be observed in a different scenario, i.e. when there is very low asset specificity, but external performance is very hard to assess? Because specific investments do not need to be secured, market relationships would best economize on transaction costs in the leading TCE view (Williamson, 1985); but at the same time, because of the difficulty in assessing the other party's performance, it would be best to vertically integrate so as to prevent it from acting opportunistically (Barzel, 1982; Zylbersztajn, 2008). Given these ideas, what would be best? Should managers integrate the transaction or carry it out on the market?

In order to build a hypothesis relating to this situation, we go back to our

Figure 4. In our representation, this particularly interesting situation would appear on the left side of $k_{1}$ and significantly above $u_{1}$. To put it differently, it would be represented in the very 
left side of the grey zone. This would provide insights in favor of the use of plural forms to solve this situation. But it still doesn't tell much neither about the underlying mechanisms nor about the composition of the resulting plural form.

Perhaps the most obvious hypothesis in this respect would be that by both producing and purchasing some of the inputs, firms gain the ability to monitor and control transacting parties, as to prevent them from acting opportunistically and this can be done in a number of different ways. For instance, firms can signal that they might stop buying at any time if performance is not satisfactory; they can benchmark performance and gain enough information to keep transacting parties in the initial agreement; or even obtain information relative to supplier cost and production techniques, among others (refer to the franchising literature mentioned in chapter 2 for further details on this matter ${ }^{34}$ ). This situation is represented in line 5 in Table 10, shown at the end of this section.

Nonetheless, just like in the franchising example mentioned before, firms could be faced with a combination of both internal and external performance assessment issues, even if asset specificity is non-significant. Once again, the benefits of combining integrated and outsourced governance modes outnumber those of solely relying on the spot market; and are similar to the ones mentioned before in this study. This situation is represented by line 6 in Table 10, shown at the end of this section.

This is why, for low (high) levels of asset specificity and high external (internal) performance assessment uncertainty (or a combination of internal and external performance assessment uncertainties), we propose the following hypothesis:

$H_{1 c}$ : Performance assessment uncertainty, when combined with low or high asset specificity, pushes towards the adoption of the 'between' type of plural forms.

However, as mentioned before, what matters the most to our study are not the 'polar' cases described above, but all the cases where $\mathrm{k}_{1}<\mathrm{k}<\mathrm{k}_{2}$ (or close to this either from the left or from the right). This is the case where hybrids would tend to dominate according to both TCE

\footnotetext{
${ }^{34}$ Although asset specificity in the franchising case is quite high, rather than low, the advantages of combining the different classes of organizational arrangements remain similar.
} 
literature and the Measurement Cost literature (the rationale behind performance assessment uncertainty is similar to that in measurement costs).

This is why we assume, for simplicity, that when the levels of asset specificity and of performance assessment uncertainty are the same, a single type of hybrid forms would emerge. But, when there are discrepancies between asset specificity and performance assessment uncertainty, various combinations of hybrids would be best.

In order to illustrate our point, assume asset specificity to be fixed at in intermediate level such that it would be best to establish relational contracts. At the same time, assume performance assessment uncertainty to be quite significant, such that adequately enforcing these contracts would require additional information. This is the case where firms could turn, in part, to formal contracts, which are less expensive to establish than vertical integration, but provide the incentives required in order to enforce the relational contracts that coexist. This is because in the event of a contract breach, firms may go to court and get part of their investment back. To put it differently, firms diversify by selecting different types of hybrids to organize these transactions. We therefore hypothesize that for intermediate levels of asset specificity:

$H_{1 d}$ : Performance assessment uncertainty, when combined with intermediate level of asset specificity, pushes towards the adoption of the 'within' type of plural forms.

To summarize the argumentation presented in this section of the paper, we have built Table 10 , below, representing the different combinations of asset specificity and both internal and external performance assessment uncertainties (the ' $\mathrm{X}$ ' representing the presence and the '-' representing the absence of the given element); as well as the expected governance modes that would be selected to best deal with each situation. Finally, we show the hypothesis to which each case is related. 
Table 10. Summary of our hypotheses relative to performance assessment uncertainty

\begin{tabular}{|c|c|c|c|c|c|}
\hline $\begin{array}{c}\text { Line } \\
\text { (combinations) }\end{array}$ & $\begin{array}{c}\text { Asset } \\
\text { Specificity }\end{array}$ & $\begin{array}{c}\text { High } \\
\text { internal } \\
\text { performance } \\
\text { assessment } \\
\text { uncertainty }\end{array}$ & $\begin{array}{c}\text { High } \\
\text { External } \\
\text { performance } \\
\text { assessment } \\
\text { uncertainty }\end{array}$ & $\begin{array}{c}\text { Expected } \\
\text { arrangement }\end{array}$ & Hypothesis \\
\hline 1 & High & $\mathbf{X}$ & - & $\begin{array}{l}\text { Plural form - } \\
\text { between }\end{array}$ & $\mathrm{H}_{1 \mathrm{c}}$ \\
\hline 2 & & - & $\mathrm{X}$ & $\begin{array}{c}\text { Vertical } \\
\text { integration }\end{array}$ & N.A \\
\hline 3 & & $\mathbf{X}$ & $\mathrm{X}$ & $\begin{array}{c}\text { Plural form - } \\
\text { between }\end{array}$ & $\mathrm{H}_{1 \mathrm{c}}$ \\
\hline $4^{\mathrm{a}}$ & Low & $\mathrm{X}$ & - & Market & N.A. \\
\hline 5 & & - & $\mathbf{X}$ & $\begin{array}{l}\text { Plural form - } \\
\text { between }\end{array}$ & $\mathrm{H}_{1 \mathrm{c}}$ \\
\hline 6 & & $\mathrm{X}$ & $\mathbf{X}$ & $\begin{array}{c}\text { Plural form - } \\
\text { between }\end{array}$ & $\mathrm{H}_{1 \mathrm{c}}$ \\
\hline 7 & Intermediate & - & $\mathbf{X}$ & $\begin{array}{l}\text { Plural form - } \\
\text { within }\end{array}$ & $\mathrm{H}_{1 \mathrm{~d}}$ \\
\hline $8^{\mathrm{b}}$ & & $\mathrm{X}$ & - & Hybrid & N.A. \\
\hline $9^{c}$ & & $\mathrm{X}$ & $\mathbf{X}$ & $\begin{array}{l}\text { Plural form - } \\
\text { within }\end{array}$ & $\mathrm{H}_{1 \mathrm{~d}}$ \\
\hline
\end{tabular}

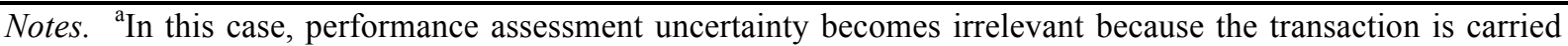
out on the market and therefore, internal performance assessment difficulties can be neglected.

${ }^{\mathrm{b}}$ In this case, performance assessment uncertainty becomes irrelevant, given that the transaction in not internalized.

${ }^{\mathrm{c}}$ This case is the same as that in line 7 because the transaction is not carried out inside the firm, so internal performance assessment difficulties become irrelevant. This is why, for simplicity, we only discuss the latter case.

It is worth pointing out that we do not hypothesize on lines 2,4 and 8 (therefore the N.A. representing 'not available') because these are the mainstream predictions. Also, it is interesting to note that high internal performance assessment uncertainty is a sufficient condition for the 'between' type of plural forms to be observed, when there are highly specific assets in the transactions at stake (i.e.: lines 1, 2 and 3 in Table 10).

Similarly, high external performance assessment uncertainty constitutes a sufficient condition for plural forms to be observed when there are either intermediate (i.e. lines 4,5 and 6 in Table 10) or low levels of asset specificity (i.e. lines 7, 8 and 9 in Table 10). Nevertheless, the resulting typologies of plural forms differ for each of the above-mentioned cases: while in the former one the 'within' type of plural forms should emerge, in the latter, it is the 'between' type that should be observed. 


\subsubsection{The combination of more than one type of uncertainty}

Discussing the correlation between a combination of two types of uncertainties and the composition of the plural form becomes interesting because it would be reasonable to assume that in the real world, firms are quite often faced with this combination. Also, it is interesting to mention that the resulting organizational arrangement might not be as intuitive as believed. We discuss these possible combinations in the next subsections.

\subsection{Market and technological uncertainties}

To begin our discussion, assume both market and technological uncertainties to be very low. This is the case of the 'pure' TCE prediction, regardless of the type of uncertainty (or combination) affecting the transaction (or family of transactions). This is why, for this case, we expect to find pure forms, as shown in Table 11, below.

Table 11. Market and technological uncertainties combined

\begin{tabular}{|c|c|c|c|}
\hline & & \multicolumn{2}{|c|}{ Technological uncertainty } \\
\hline & & Low & High \\
\hline & Low & Pure forms & Between pure \\
\hline $\begin{array}{c}\text { Market } \\
\text { uncertainty }\end{array}$ & High & $\begin{array}{l}\text { Between pure } \\
\text { forms }\end{array}$ & $\begin{array}{c}\text { forms } \\
\text { Between pure } \\
\text { forms or combo } \\
\text { forms } \\
\end{array}$ \\
\hline
\end{tabular}

However, as discussed before in this paper, both high market uncertainty and high technological uncertainty alone would push towards the adoption of the 'between' type of plural forms (for a given level of asset specificity); although not necessarily to the same combination of organizational arrangements in the plural form. For instance, a given firm might turn to the spot market and to vertical integration in order to deal with high market uncertainty. The same firm might make use of relational contracts and vertical integration in order to deal with high technological uncertainty, for the same given level of asset specificity.

We also submit that the mere existence of high uncertainty of one and of another kind, at the same time, would require the firm to establish the combination of organizational arrangements 
that best deals with each type of uncertainty alone; regardless of the respective strengths of one type of uncertainty relative to the other.

For example, assume that in order to deal with high market uncertainty (and a certain fixed level of asset specificity) a given firm would both produce and purchase inputs on the spot market. Assume next that in order to deal with high technological uncertainty (and a certain fixed level of asset specificity), the same firm both purchases on the spot market and uses long term formal contracts.

Given this example, the combination of both types of uncertainties, for the same given level of asset specificity, will require that firms combine all three organizational arrangements in order to adequately deal with the different uncertainties: spot market, long term formal contracts, and vertical integration. This is why, when both high market uncertainty and high technological uncertainty affect a given transaction, we should expect the 'between' type of plural forms.

However, it could also be the case where the combination of organizational arrangements used in order to deal with type of uncertainty involves different typologies of hybrid arrangements (one type of hybrid arrangement in each 'between' type of plural forms).

For instance, assume that in order to deal with high market uncertainty, for a given level of asset specificity, a firm makes use of relational contracts and the spot market to obtain its inputs. Now assume that this same firm is also faced with high technological uncertainty and that in order to best deal with it, it makes use of both long term formal contracts and vertical integration. Therefore, according to the assumption underlying this section, the resulting combination of organizational arrangements used in order to deal with both high market uncertainty and high technological uncertainty would be composed of the spot market, of relational contracts, of long term formal contracts and of vertical integration.

What is noteworthy in this second example is that the combination of two plural forms of the 'between' type results in a 'combo', rather than in the 'between' type of plural forms. After all, according to the definition of the 'combo', different types of hybrid arrangements would be required to compose it and that would only be possible, when combining two 'between' 
types of plural forms, when each of them involves a different type of hybrid arrangement. Thus, this becomes a necessary condition for the 'combo' type of plural forms to emerge, rather than the 'between' type of plural forms.

Therefore, this discussion leads us to build the following two hypotheses:

$H_{1 e}$ : The combination of high market uncertainty with high technological uncertainty pushes towards the adoption of the 'between' type of plural forms when each one of the 'between' type of plural forms composing the mix does not involve different typologies of hybrid arrangements.

$H_{1 f:}$ The combination of high market uncertainty with high technological uncertainty pushes towards the adoption of the 'combo' type of plural forms when each one of the 'between' type of plural forms composing the mix involves different typologies of hybrid arrangements.

\subsection{Market or technological uncertainties and performance assessment uncertainty}

Just like in the preceding subsection, begin by assuming both market and technological uncertainties to be very low. Once again, this would be the case of the mainstream 'pure' TCE prediction, regardless of the type of uncertainty (or combination) affecting the transaction (or family of transactions). This is why, for this case, we expect to find pure forms, as shown in Table 12 below.

Table 12. Market or technological uncertainties and performance assessment uncertainty combined

\begin{tabular}{cccc}
\hline & \multicolumn{2}{c}{ Market or technological uncertainty } \\
& Low & Low & High \\
\cline { 3 - 3 } $\begin{array}{c}\text { Performance } \\
\text { assessment } \\
\text { uncertainty }\end{array}$ & High & $\begin{array}{c}\text { Within hybrid } \\
\text { forms or between } \\
\text { pure forms }\end{array}$ & $\begin{array}{c}\text { Between pure } \\
\text { forms } \\
\text { forms or combo } \\
\text { forms }\end{array}$ \\
\hline
\end{tabular}


However, as discussed before, both high market uncertainty and high technological uncertainty alone would push towards the adoption of the 'between' type of plural forms (for a given level of asset specificity); whereas high performance assessment uncertainty might push either to the 'between' type of plural forms or to 'combo' forms, depending on the source of performance assessment uncertainty (internal or external) and the degree of asset specificity involved in the transaction (or family of transactions) at stake.

Also, just like in the preceding subsection, we argue that the mere presence of a given type of uncertainty in non-trivial degrees will require the firm to establish the combination of governance mechanisms that best deals with this type of uncertainty. Therefore, once again, the combination of two types of uncertainties will push towards the simultaneous adoption of the combination of organizational arrangements that best deals with each type of uncertainty affecting the transaction.

Just like in the preceding subsection, when two types of 'between' plural forms are combined in order to best deal with the combination of high uncertainties affecting a transaction (or family of transactions), we build the following two hypotheses:

$H_{\text {lg: }}$ The combination of high market or high technological uncertainty with high performance assessment uncertainty pushes towards the 'between' type of plural forms when each one of the 'between' type of plural forms composing the mix does not involve different typologies of hybrid arrangements.

$H_{1 h}$ : The combination of high market or high technological uncertainty with high performance assessment uncertainty pushes towards the 'combo' type of plural forms when each one of the 'between' type of plural forms composing the mix involves different typologies of hybrid arrangements.

The fundamental difference here is that the 'within' type of plural forms might emerge when performance assessment uncertainty alone affects a given transaction (or family of transactions) and this might favor the likeness of the 'combo' type of plural forms when such high uncertainty is combined with either high market or with high technological uncertainty. After all, if we combine the 'between' type of plural forms used to deal with high market or 
with high technological uncertainty with the 'within' type used to deal with high performance assessment uncertainty, it is only logical that we will find the 'combo' type of plural forms, by definition. Therefore, we present the following hypothesis:

$H_{1 i}$ : The combination of high market (or high technological) uncertainty with high performance assessment uncertainty pushes towards the 'combo' type of plural forms when the 'within' type of plural forms is involved in the combination.

Of course, the likeness of $\mathrm{H}_{1 \mathrm{i}}$ would depend on the probability that each of the conditions required for this mode of organization to emerge be satisfied. As discussed before in this paper, the 'within' type of plural forms would occur only if asset specificity is intermediate and there is high performance assessment uncertainty. Therefore, given that these conditions are satisfied, the 'combo' type of plural forms will be more likely than in the case described in the preceding subsection.

\subsection{Final remarks}

In this chapter, we have made an advance in an emerging concern relative to plural forms, that is, clarifying the wide variety of combinations of organizational arrangements. In particular, we have managed to build an integrative model of asset specificity and uncertainty not only to predict when plural forms should or should not be observed, but also, to dig further into the variety of plural forms.

In that respect, we built hypotheses on the correlations between the type of uncertainty (high market uncertainty, high technological uncertainty and high performance assessment uncertainty) affecting a given transaction (or family of transactions) and the resulting types of plural forms ('between', 'within' and 'combo').

Therefore, we have taken a step ahead of existing literature in that we attempt to predict the typologies of plural forms according to the conditions under which decision-makers operate. This might help managers shape their sourcing strategies, once we provide a toolbox to determine whether pure or plural forms are best, and in this latter case, which typology is best suited; although we do not clearly state neither which particular combination should be used nor the relative weights of each organizational arrangement. 
Regardless of this fact, we push the existing contributions in this field further in that we provide a clarification for additional types of plural forms, going beyond making-and-buying or buying-and-allying. In this sense, we develop a richer understanding of hybrid arrangements, and in particular, of the multiple combinations involving them.

Because our argumentation has remained strictly theoretical and qualitative, further empirical contributions should confront them with real-world evidence; both in qualitative and in quantitative dimensions. In that respect, both upstream (sourcing) and downstream (distribution) transactions are interesting candidates to confront our hypotheses.

Other interesting contributions, both in empirical and in theoretical terms, would consist of the examination of the relative weights of each organizational arrangement composing the plural form. Questions such as "how much should be obtained from each organizational arrangement" or "is there a dominant organizational arrangement in the plural form?" are interesting paths for future research related to this chapter. In a very preliminary way, it is possible to conjecture that there would be a dominant organizational arrangement in the plural form. But we leave this challenging idea to future contributions in this field. 


\section{Chapter 4}

\section{Predicting plural forms and diversified organizational arrangements with the combination of asset specificity and uncertainty: a case study in Brazil}

\subsection{Introduction}

In this paper, we present some empirical evidence to qualitatively illustrate the framework we develop in chapter 3 , i.e. that an integrative perspective of asset specificity and uncertainty would predict when plural forms should or should not be observed. More specifically, we argue that plural forms would be predicted only when specific assets are at an intermediate level and when the level of uncertainty affecting the transaction(s) at stake is relatively high.

Moreover, to predict when plural forms should not be observed (or conversely, when nonplural forms should prevail), we follow Williamson (1991), who argues that when the level of uncertainty affecting a given transaction is low, hybrid arrangements would be selected when specific investments are at the intermediate level. However, when these specific investments are too low or too high, pure market or pure hierarchy arrangements (respectively) should prevail (Williamson, 1991), regardless of the level of uncertainty affecting this given transaction.

Therefore, in this empirical paper, we address the following question: can the combination of asset specificity and uncertainty predict the emergence of plural forms? Additionally, we follow the reasoning discussed above and push our framework further, as we also intend to verify whether or not different levels of uncertainty and of asset specificity (combined) determine the selection of distinct organizational arrangements.

In order to provide an empirical illustration of our ideas and to provide an answer to our research questions, we perform a clinical case study at the Korin Company in Brazil, which 
produces and commercializes a wide variety of organic products. In particular, we describe and analyze the procurement of different inputs, bearing distinct levels of asset specificity and of uncertainty. Hence, we perform a comparative analysis of these data to validate our theoretical framework and to verify whether such variety in terms of asset specificity and uncertainty will lead to different organizational arrangements.

Our intention in selecting the procurement of different products within the same firm is that of better isolating the effects of asset specificity and of uncertainty when analyzing the decision for one or for another organizational arrangement. We, therefore, deliberately choose to lose generality and to remain exploratory in favor of better understanding the effects of our variables of interest over the governance decision. After all, this is to our knowledge the first paper to empirically verify the possibility of predicting organizational arrangements, both non-plural and especially plural forms, by analyzing the combination of asset specificity and uncertainty.

\subsection{Analytical framework}

Our analytical framework is based on the idea that the combination of asset specificity and uncertainty makes room for plural forms in the Transaction Cost Economics model (Williamson, 1985, 1991). To this end, we follow Williamson (1991), Parmigiani (2007), Krzeminska (2008), Mols (2010) and Menard (2013, 2014) to build an integrative perspective of asset specificity and of uncertainty to predict plural forms or non-plural forms.

Following Williamson (1991), we hypothesize that when asset specificity is very low, the pure spot market should be the best organizational arrangement, regardless of the degree to which uncertainty is present. This is because in this scenario, agents can be easily replaced in the event of a disturbance and, therefore, these transactions can be effortlessly (and potentially costlessly) rearranged. Therefore, the lower the degree of asset specificity, the higher the uncertainty that will be necessary in order for any organizational arrangement to outperform the pure spot market (see the 'U' shaped curve in Figure 5).

Conversely, when investments are dedicated, the pure hierarchy should prove to be the only efficient solution, regardless of the uncertainty affecting the transaction. Once again, the 94 Predicting plural forms and diversified organizational arrangements with the combination of asset specificity and uncertainty: a case study in brazil 
explanation for this proposition is based on the transaction costs of arranging and rearranging these transactions. To summarize the rationale here, it could be argued that specific investments require complex safeguards that are prohibitively costly to establish between external contracting parties and therefore, vertical integration becomes the less costly way of safeguarding these investments; regardless of the level of uncertainty affecting the transaction (Williamson, 1991). Therefore, the higher the level of asset specificity, the higher the uncertainty that is required in order for any organizational arrangement to outperform the pure hierarchy (see the ' $U$ ' shaped curve in Figure 5).

Between these two polar cases, however, we submit that various modalities of plural forms would develop if uncertainty is non-trivial (the grey zone in Figure 5); and hybrid arrangements would prevail when uncertainty is low - below u1 (Williamson, 1991). This is because the efficiency of hybrid arrangements is more likely to deteriorate under high uncertainty (Williamson, 1991), especially because of the need to coordinate the response of both parties composing this arrangement. As a consequence, hybrid arrangements are more likely to be replaced by plural forms (or conversely, a lower level of uncertainty is required in order for plural forms to outperform non-plural forms when specific investments are at an intermediate level).

In this paper, we follow this idea and its associated theoretical model, already developed in chapter 3, but push it further in the sense that not only we are interested in verifying whether or not the levels of asset specificity and of uncertainty affecting each transaction will fall within or outside the grey-zone, but also, in assessing how different transactions (namely, the procurement of products bearing different levels of asset specificity and uncertainty) can be distributed in Figure 5. Our intention in doing so is that of picturing the effect of the combination of distinct levels of asset specificity and of uncertainty in the choice for one or another organizational arrangement. 
Figure 5. An integrative perspective of asset specificity and uncertainty and our contribution

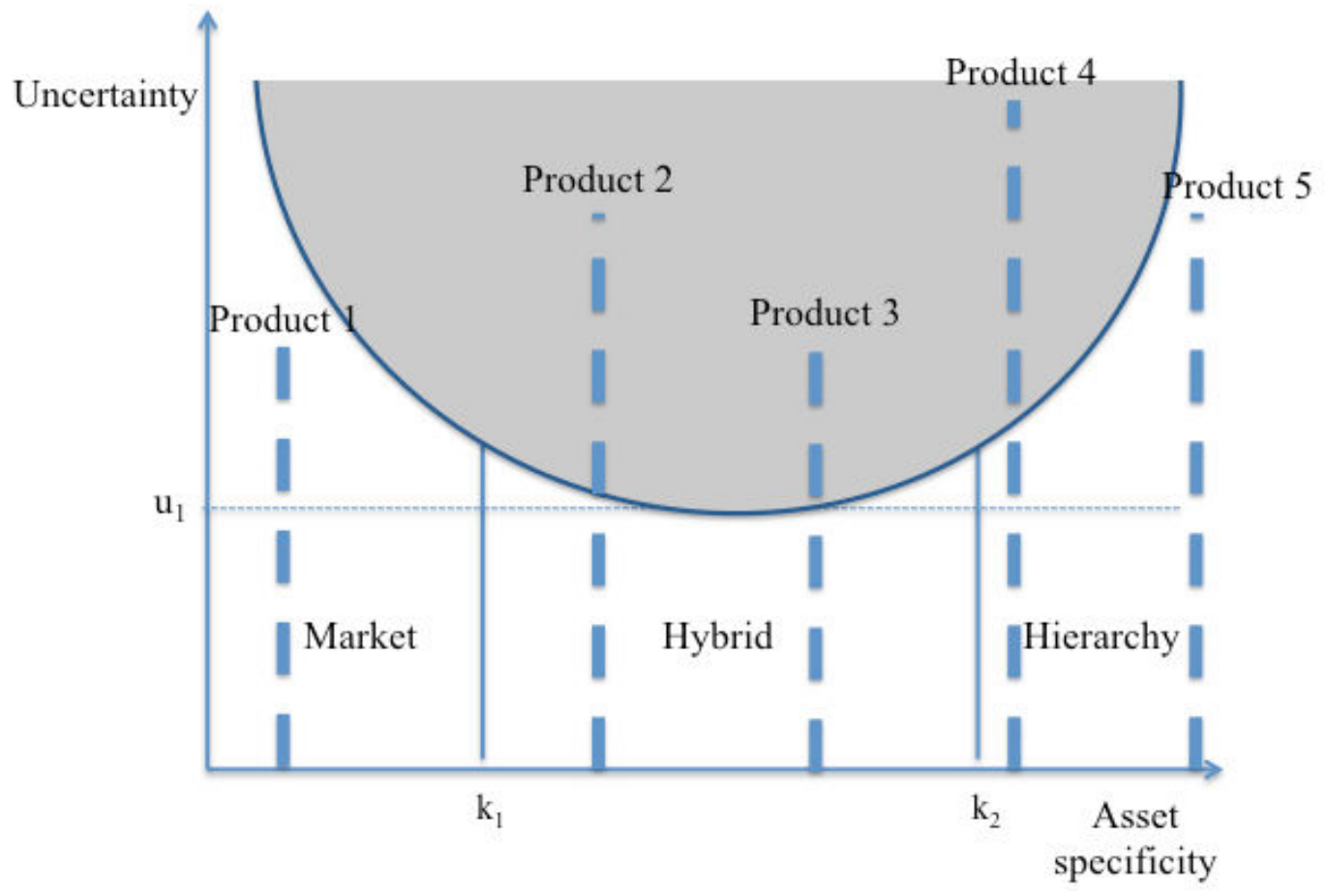

To give more substance to the argument developed above, let us consider that the transactions to procure each product (abstractly identified as 1, 2, 3, 4 and 5) in Figure 5 are subject to different levels of uncertainty and of asset specificity. Our fundamental hypothesis, derived from the framework above, is that these variables would explain why each of these products is carried out by using one or another arrangement.

For instance, because the procurement of the abstract product 1 bears very low levels of asset specificity (below $\mathrm{k}_{1}$ ), we could predict that it would be carried out in the pure spot market, even though there is quite significant uncertainty affecting such transaction (above $\mathrm{u}_{1}$ ). Conversely, because the procurement of product 5 involves highly idiosyncratic assets (above $\mathrm{k}_{2}$ ), the Williamsonian model predicts that it will be carried out in the pure hierarchical arrangement, regardless of the high uncertainty affecting it (above u1). However, and this is the hard core of our contribution, because the procurement of products 2, 3 and 4 involves intermediate levels of asset specificity (between $\mathrm{k}_{1}$ and $\mathrm{k}_{2}$, or close to them either from the left or from the right) and high uncertainty (above $\mathrm{u}_{1}$ ), plural forms would be selected to organize them. 


\subsection{Method and data collection}

To empirically verify our analytical framework, we make use of clinical case studies (Baker \& Gil, 2013). These particular types of cases are detailed descriptions (or 'stories') of a particular situation or phenomenon, making use of qualitative and sometimes of quantitative data (coming from primary and secondary sources) to provide a comprehensive account of the situation at stake (Baker \& Gil, 2013). They often contain data that is not amenable to statistical analysis (Baker \& Gil, 2013).

These descriptions (or 'stories') are the product of observation and hypotheses generation, serving, therefore, four main purposes: "(1) telling theorists what to model, (2) providing guidance on how to model these things, (3) assessing "possibility theorems", and (4) providing evidence of a certain type for testing theory." (Baker \& Gil, 2013: 196).

They are, hence, well suited to assist scientists when there is no theory or when very little is known about a given phenomenon (Eisenhardt, 1989; Baker \& Gil, 2013). This is why Eisenhardt (1989) and Eisenhardt and Graebner (2007) encourage and describe a process for building inductive theory based on this type of empirical research.

In this paper, we choose to perform a clinical case study in order to test a new theoretical model and to potentially obtain novel insights related to this model. It is, according to Eisenhardt (1989) and to Baker and Gil (2013), a well-suited technique to accomplish our objective.

Although clinical case studies can be composed of single or of multiple cases, we have chosen to perform a very particular type of single clinical case study: the embedded type of case (Yin, 2003). It consists of a single case that is composed of a number of subunits that are individually analyzed and collectively compared. For instance, this could be the case of a multidivisional firm, whereby each division is individually analyzed and compared to the others (Yin, 2003).

It is an interesting type of case because, although one is dealing with subunits of the same case, the collection of individual analysis and comparisons of each of these units may actually 
approach the characteristics of a multiple case study, although allowing us to keep constant some external variables. For instance, in the case of the multidivisional firm mentioned before, each division could be regarded as an individual firm, and therefore, their collective analyzes would be similar to that in a multiple case study. However, because they belong to the same firm, a number of variables remain the same, for example, internal policies (formal and informal rules), culture, information technology and other shared values remain constant. And because they are in the same firm, the social context where the situation takes place also remains constant. Indeed, because case studies are well suited exactly for those situations where it is hard to separate the phenomenon of interest from the social context where it takes place (Yin, 2003), having multiple units within the same context becomes a great advantage. After all, they are all subject to the same context and therefore, comparing them and isolating the variables of interest becomes a lot easier. For didactic purposes, what we mean here is that this effect would be somehow similar to that of establishing a number of control variables, but in situations where these cannot be separated from the variables of interest.

To develop this approach to a specific case with numerous subunits, we have selected the Korin company. Our choice is based on the fact that this firm procures a number of different products, both by means of non-plural and of plural forms. Therefore, the embedded clinical case will provide us with an understanding as to why Korin adopts plural forms to procure some products, but turns to non-plural forms to procure others.

By doing so we will be able to better focus on our variables of interest, since all sourcing decisions are made within the same firm. Therefore, we will fix the context where these transactions occur to better observe our phenomenon of interest. We are aware that this choice does not come free of limitations: our conclusions will of course be valid for Korin, but could not be generalized without investigating similar situations on a large set of cases. This is a well-known limitation of the case study method in general, be it for a single company or for multiple ones.

With these limitations in mind, we explore the relevance of our hypotheses through a case (Korin) composed of the following subunits operating within the same firm: poultry, regular soybeans, regular corn, organic corn and antibiotic-free eggs. These subunits consist either of

98 Predicting plural forms and diversified organizational arrangements with the combination of asset specificity and uncertainty: a case study in brazil 
the most important products in terms of revenue for the firm (poultry and eggs) or of the most important inputs to produce these products (soybeans and corn), as depicted in Figure 6 .

Figure 6. Embedded case study - subunits of analysis in the Korin case.

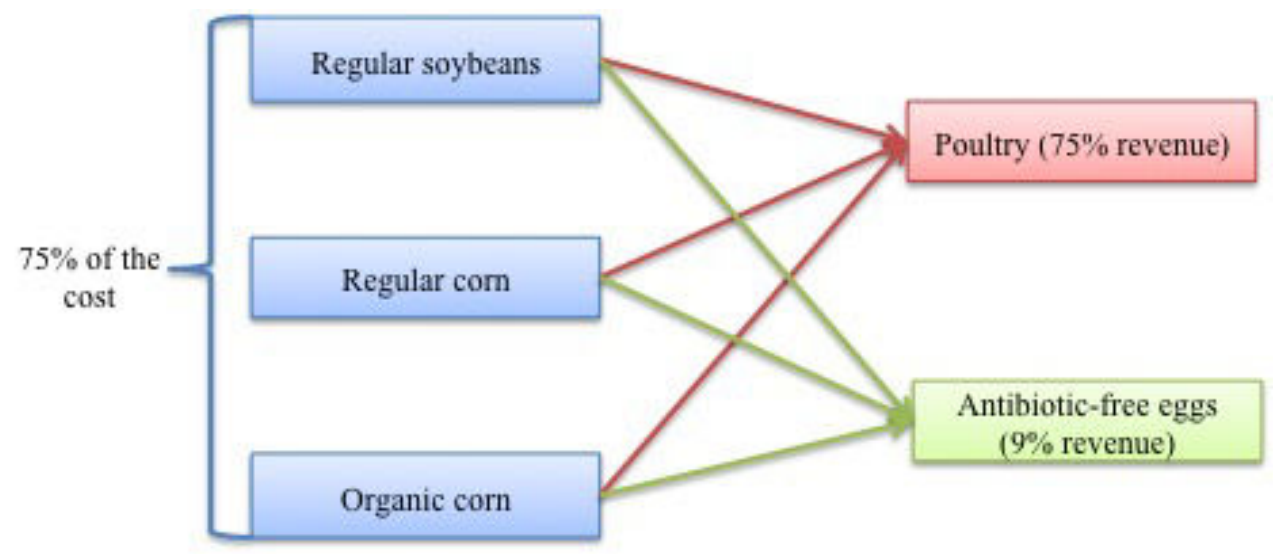

In particular, we are concerned with the ways by which each of the subunits mentioned before are procured. To keep our analyses tractable, we classify the alternative organizational arrangements in the following way: first, we divide the total quantity into what is obtained inhouse versus what is outsourced. Next, we classify the percentage that is outsourced (when available) in three ways: spot market, relational contracts and formal contracts. Finally, we take care to explore and expose different contracting particularities, whenever differences exist within each of the hybrid categories defined above. Such method is based on Menard et al (2014).

We also follow Menard et al (2014) to construct the semi-structured questionnaire that guided our interview with the company (see the appendix). Essentially, what we want to capture with our questionnaire are both general characteristics of the company (such as its history, size, products, ideals, etc.) and specific characteristics of the transactions of our interest (such as the historical path, the ways by which they are procured, the motivations for this choice, etc.). We also intend to measure both asset specificity and uncertainty for each transaction of interest, although this latter variable cannot be objectively measured by definition. However, we do make an effort to measure the manager's perception of the magnitude of this variable, although we are not interested in obtaining any metrics, but in the relative magnitudes of the uncertainty affecting the procurement of each of the subunits mentioned before. 
To this end, we develop the analysis in Menard et al (2014) further and define three types of uncertainty that capture the essential dimensions of the concept, according to the recent literature in organizational economics (Parmigiani, 2007; Menard, 2013): i. market uncertainty, which captures situations in which agents are uncertain about the fluctuations of supply and demand (Robertson \& Gatignon, 1998), ii. technological uncertainty, in which agents are uncertain about technological variety and volatility, and iii. performance assessment uncertainty, whereby observing and measuring the adherence of the transacting parties to the contractual arrangements is hard and/or it is not easy to measure the performance of these parties (Barzel, 1982). These three dimensions of uncertainty, in association with asset specificity, might push towards the adoption of plural forms.

Because 'ambiguity' (Menard et al, 2014) was measured by the perceived volatilities of supply and demand, we considered 'ambiguity' a good proxy for market uncertainty, as defined above. Hence, we decided to keep those questions assessing 'ambiguity' in Menard et al's (2014) questionnaire.

Similarly, because 'complexity' (Menard et al, 2014) was measured by a collection of questions assessing the perceptions for technological variety and volatility, we considered it a good proxy for technological uncertainty, as defined above. We, therefore, decided to keep those questions assessing 'complexity' in Menard et al's (2014) questionnaire.

Finally, to capture the third dimension of uncertainty (performance assessment uncertainty), we decided to keep some questions from Menard et al's (2014) questionnaire that assessed the perceived inability to measure the suppliers' production in terms of quantity and quality and about the potential variations in these variables; but we also introduced some complementary questions that more explicitly captured this concept. For instance, we measured the perceived possibility of measuring both employees' and suppliers' productivities and their respective possibility of concealing the actual production/quality or even that of cheating.

And because uncertainty must motivate to adopt plural forms when in association with asset specificity, we keep some questions in Menard et al's (2014) questionnaire that measured human, temporal, site and technical asset specificity. These seem to be the most relevant dimensions of asset specificity in agricultural markets because these products tend to be 100 Predicting plural forms and diversified organizational arrangements with the combination of asset specificity and uncertainty: a case study in brazil 
perishable (hence, temporal and site specificities) or they may require special knowledge or machinery (human and technical specificity), for instance, in the case of organics, where production techniques differ from the conventional process.

Therefore, most questions in our questionnaire overlapped with those in the case studies on plural forms in Menard et al (2014), with the exception of those that we introduced in order to more explicitly capture our variables of interest, as mentioned before.

It is worth mentioning, once again, that we do not attempt to objectively quantify these variables; but measure the manager's perceptions of their magnitudes. Our objective with these measures is that of getting an understanding of these variables in order to build a comparative set of analyses for our collection of subunits. Therefore, what are relevant to us are the relative magnitudes of these variables in each of the subunits composing our case.

Bearing this in mind, we present next our collection of subcases and our analyses, focusing of both asset specificity and multiple types of uncertainty. Finally, we compare all the subcases and confront them with our theoretical predictions.

\subsection{An empirical investigation}

\subsubsection{The clinical cases - Korin}

Korin was founded in 1994, based on the principles of Nature Farming laid out by Mokiti Okada, a Japanese philosopher and spiritualist (1882-1955) (Korin, 2013). Specifically, its establishment was driven by the dissemination of the alimentary ideals carried out by the World Messianic Church which, in turn, relates to Okada's concepts of Nature Farming ${ }^{35}$.

This is a philosophical model, originating in $20^{\text {th }}$ century Japan, dealing with the understanding and application of the forces of nature aimed at agricultural production and the maintenance of human health, which basically happens through the consumption of natural foods (Demattê Filho, 2004). According to the precepts of this philosophy, the

\footnotetext{
${ }^{35}$ Despite the ideals motivating it's establishment, one must recall that this is a for-profit company. Since 2007, it has been adopting practices to maximize it, such as turning to more professional managing techniques. Since then, profits have been increasing rapidly (Demattê Filho,2014).
} 
consumption of natural foods, free of the toxins coming from fertilizers and agrochemicals, is fundamental to guarantee good human health (Demattê Fillho, 2004).

This philosophy was brought to Brazil in 1954 by Japanese immigrants, members of the Messianic Church, who became rural producers in Brazil or influenced already established producers, and who began to produce vegetables in accordance with the precepts of Nature Farming. Initially, the production was for their own consumption and for sale among the members and sympathizers of the Church, which continually sought to spread the word of its agricultural model, going as far as acquiring properties to develop this model.

In the mid-1990s, an area of 174 hectares was acquired in Ipeuna, São Paulo state (Demattê Filho, 2004), where the Mokiti Okada Center for the Promotion of Nature Farming was established. In 1994, the Center was renamed the Mokiti Okada Research Center. Following this process was the need for increased access to markets for the products, which would require a firm for producing and marketing, instead of a foundation. Thus, in 1994 Korin Agropecuária LLC was founded based on the ideals of Nature Farming, which fall under the guidelines of the law that regulates the production of organic food in Brazil, thereby allowing Korin's products to obtain the Brazilian organic certification (Korin, 2013).

Korin offers Brazilian consumers a wide range of products, including chicken, eggs, fruits, vegetables, mineral water, compounds for agricultural use, instant soups, coffee powder and beans, and honey and honey products. In terms of vegetables, the firm focuses on: lettuce, broccoli, cauliflower, endive, spinach, zucchini, potato, eggplant, beets, carrots, corn, cucumber, tomato, and green beans, among others, whereas fruit production comprises mainly strawberry, mango, yellow melon, and sweet orange (Korin, 2013). It is the largest producer of these natural and organic products in Brazil (Demattê Filho, 2014).

\subsubsection{Korin and its sustainable production}

Since its establishment in mid-1994, Korin has provided consumers with the results of its ongoing investment in research and technological development, to better operationalize the ideals of Mokiti Okada. One of the most visible results so far is its pioneering creation of chicken free from antibiotics and artificial growth hormones (Demattê Filho; Mendes, 2001; 
Demattê Filho, 2004), which increased both the recognition of the brand and the company's market (Korin, 2011).

Since then, other "alternative" varieties of chicken have been developed, such as organic and free range, produced strictly in accordance with the norms and standards required by certification bodies that regulate the sector (Korin, 2011). It is important to note that in addition to meeting the guidelines required by these entities, the company has earned the Humane Farm Animal Care (HFAC) certification (Korin, 2011), since the practice of Okada's ideals corresponds exactly to the humane farming requirements imposed by this certification body.

This natural, pesticide-free agriculture (Korin, 2011), in keeping with Mokiti Okada's legacy, does not only bring its livestock into compliance with the guidelines of certifying bodies. In fact, Korin's natural production of vegetables, which anticipated its chicken farming activity, meets the requirements of the act 10.831 , as of December $23^{\text {rd }} 2003$, which regulates the production of organic food in Brazil. In other words, although the differentiated production of vegetables had been motivated by the goal of following Okada's teachings, it received organic certification because its practices meet the legal framework of the guidelines for organic products.

Korin produces and markets a wide range of organic products in addition to chicken, including eggs, fruit, vegetables, mineral water, microbiological fertilizers, coffee, and honey and derivatives. The legumes and vegetables, produced in a traditional manner in Brazil since the 1950s by Japanese immigrants following Okada's ideology, include: lettuce, broccoli, cauliflower, endive, spinach, zucchini, potatoes, eggplant, beets, carrots, corn, cucumber, tomato and green beans; while fruit production comprises mainly strawberry, mango, yellow melon, and "pear" oranges (Korin, 2011).

\subsubsection{Organizational arrangements}

Korin organizes the supply of the wide variety of products mentioned before in different ways. Some are produced in-house while others are outsourced; or even obtained by means of a combination of in-house production and outsourcing. 
Therefore, in the next subsections, we will show why Korin has chosen to obtain some products by means of plural forms and others through non-plural forms. To this end, we will first describe the situation at stake for each sub-case: poultry, regular (or standard) soybeans, regular (or standard) corn and organic corn. Next, we will analyze, for each sub-case, our variables of interest: asset specificity and uncertainty. In particular, we will show that these two variables motivate the choice of one or another organizational arrangement.

We have organized the analyses mentioned before as follows: first, we address the sub-cases for which the procurement of inputs is made by non-plural forms (they are either procured on the spot market, or integrated, or acquired through a hybrid arrangement): poultry and regular (or standard) soybeans. Next, we expose the sub-cases for which the main input is procured with plural forms: regular (or standard) corn, organic corn and antibiotic-free eggs.

\subsubsection{Poultry}

Poultry is the most important product composing Korin's portfolio. Not only does it correspond to $75 \%$ of the company's income, but it also motivated the establishment of the firm (as distinct from the Foundation) in the first place, back in the 1990's, as a pioneer in the production of organic and antibiotic-free poultry.

The development of the technology required in order to produce both the organic and the antibiotic-free varieties of poultry is by no means a trivial endeavor. Rather, it resulted from 10 years of research based on Okada's philosophy of only consuming foods that are free from chemicals and pesticides. This is because said technology must comply with the legal standards that are necessary for the product to be certified and commercialized as organic, which requires the producer to adopt a number of differentiated practices in its production process.

First, poultry is raised free within a delineated area in the farm, where the birds can circulate, run and even catch some sunlight, and in a low density of animals per square meter; rather than confined in small cages (typically the size of an "A4" sheet of paper), which often bruise the birds' feet, and with a high density of animals per square meter. 
Second, because they are raised free, these animals do not become as stressed as those raised in the conventional production process. Therefore, they are not pecked, as the conventional birds are, because they do not develop aggressive behavior. Moreover, because they are not pecked, they become less likely to develop diseases typically associated with such practice. Finally, when they do become sick, the organic animals are not treated with antibiotics, but with natural products. This is a world-renowned technology, and one of the most famous cases is the French 'Label Rouge' (for a case study on these organizational arrangements, see Menard, 1996).

Despite all these differences relative to the conventional production techniques, the greatest challenge that Korin had to overcome was that of feeding these special birds. This is due the fact that there are many restrictions in terms of what the birds can or cannot consume in order for the poultry to be certified and sold as organic (or as antibiotic-free). In that respect, it is imperative that they are fed with organic food that is also free from agrochemicals.

This is why Korin decided to feed them, first, with a mixture of organic corn, soy chaff and soybean oil. But the problem was that the oil suffered an oxidative process, which rendered the animals sick. And associating the oil with the cause of such diseases was very timeconsuming and costly. But once the problem had been identified, another challenge arose: how could the oxidative process be avoided without adding chemicals to the mixture?

After conducting a lot of research, Korin found that the birds could be fed with a mixture of organic corn, soy chaff and whole soybeans, even though these latter crops need to be boiled. Therefore, when composing the mix, they release oils that are consumed before oxidation and thus, do not render the animals sick. And because finding out the exact composition of this mixture is hard, not only does Korin integrate its production, but it remains to date the sole player in the Brazilian market for antibiotic-free poultry (which is the most restrictive special type of poultry).

Besides the specificities that are necessary to produce these special varieties of poultry, the production process of poultry in general requires large investments, especially in order to build the slaughterhouse and to meet the scale requirements in order for the firm to become competitive. 
In order to understand such requirement, one must note that the Brazilian poultry market is dominated by very large firms, exporting a significant amount of the product. The problem here is that when shocks occur in international markets, all the remaining poultry is sold in Brazil and this fact evidently lowers (a lot) the price of the product in the domestic market. But because small producers would have already incurred production costs, which are typically higher than those of large firms (because of scale economies), this lower price might even become lower than the cost itself. This is why scale constraints become so important in this market.

Take for instance what happened in 2006. It is noticeable in Figure 7 that prices dropped by $38 \%$ in Sao Paulo from January until March. This is because many foreign countries, mostly in the European Union, suspended their imports of Brazilian poultry due to the appearance of the first cases of the bird flu in Europe, back in November 2005. As a result, the exported volume of the product fell from over 250 thousand tons (October, 2005) to 182 thousand tons (January, 2006) (Dieese, 2006). And because it is impossible to instantaneously reduce the production of poultry, the domestic market had to absorb all the excess, which was not exported. As a result, prices dropped considerably in Brazil (Dieese, 2006).

Figure 7. Refrigerated chicken price and volatility

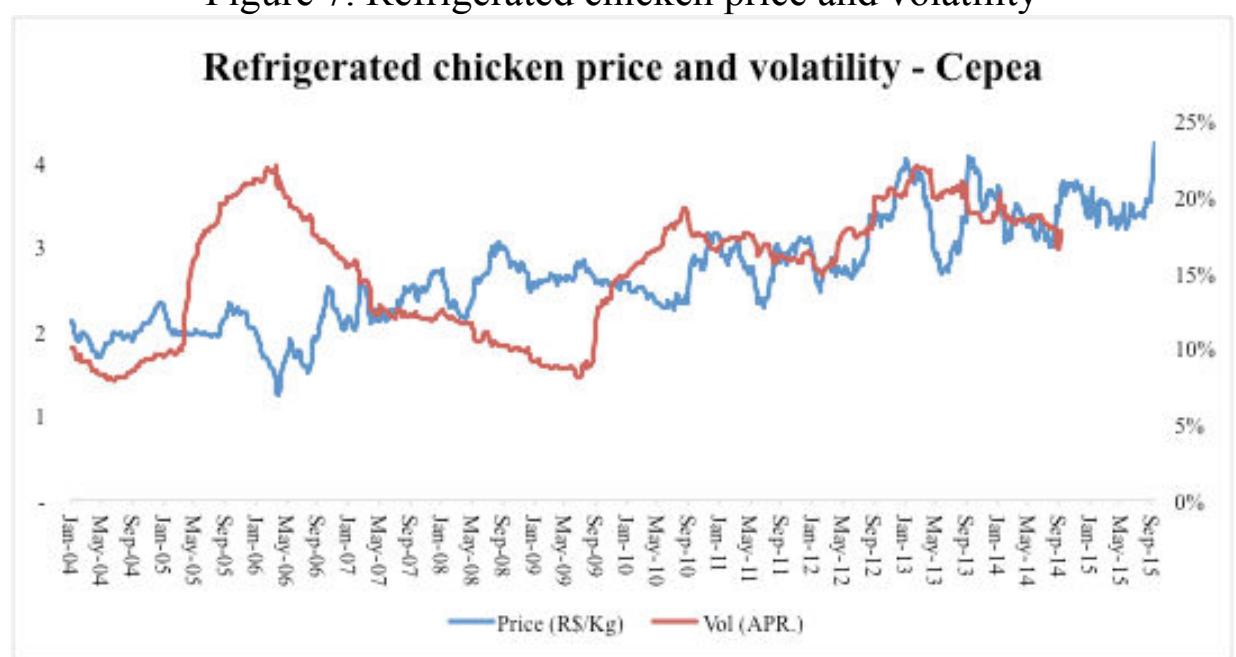

Source: Based on data retrieved from Cepea (2015)

Considering that small producers typically have a higher cost relative to large producers, they are more susceptible to present very low or even negative profits when these 'price shocks' occur. And given that there is considerable volatility in this market (see Figure 7), 
scale constraints become crucial to guarantee competitiveness in this sector.

Therefore, given all the specificities mentioned before, Korin produces in-house $100 \%$ of its needs for poultry, as shown in Table 13, below.

Table 13. Forms of obtaining chicken $(\%)$

\begin{tabular}{ll}
\hline Own production & $100 \%$ \\
Outsourced production & - \\
Spot market & - \\
Relational suppliers (no formal & - \\
contract) & \\
Suppliers with formal contracts & - \\
\hline
\end{tabular}

\subsection{Main reasons for the choice to vertically integrate the production of poultry: asset specificity and uncertainty}

\subsection{Asset specificity}

As illustrated in this section, the level of asset specificity required to produce organic or antibiotic-free poultry is very high (or even dedicated). This is not only due to the differentiated production process, which by itself increases asset specificity, but also, because of the challenge of developing the special food for the birds. And as a matter of fact, Korin is the only company that is able to produce it. Moreover, the scale constraints and the high investments that are needed in order to build the slaughterhouse increase even more such specificity.

\subsection{Uncertainty}

Market uncertainty, in the poultry supply chain in general, is quite significant. First, as already mentioned, because the market is dominated by large players selling both in domestic and in international markets, demand shocks, mainly overseas, cause great price volatility (either up or down - on average, there was $15 \%$ per year volatility over the last 11 years, with a variation from $8 \%$ per year to $22 \%$ per year). Second, because organic birds are fed solely with corn and soybeans (and their derivatives), their market price volatility introduces some 
significant uncertainty in the cost of the product (see the next subsections for more information on the price volatilities of these commodities). Therefore, because the poultry supply-chain bears significant uncertainties on both the supply and demand sides, we can consider it a highly uncertain market.

\subsection{Organizational arrangement decision}

To sum up, these are strong indicators suggesting that Korin integrates the production of poultry because there are significant uncertainty and very high levels of asset specificity. Therefore, this transaction falls outside the grey zone in our model. Moreover, because of the high level of asset specificity, the transaction is, as predicted in line with the standard Williamsonian approach, integrated (and not carried out on the market).

Regular (or standard) soybeans are used in small proportions to feed Korin's chicken, which either result in poultry or in eggs. These beans are commodities and may be substituted for the organic variety at a higher cost, if not made available in quantities enough to guarantee the desired production (regular grains may compose the animal's feed in a proportion smaller than $15 \%$ of the total weight). Therefore, even though they are used as inputs for the company's main products, regular soybeans are not as important to Korin as the organic variety or as corn, also composing the animals' feed. However, because it accounts for a large share of the company's cost (soybeans and corn, combined, correspond to $75 \%$ of the cost), it is important to obtain it in the right amount and price: substituting it for the organic variety would increase production cost.

Korin turns to suppliers with formal contracts to this end, as shown in Table 14 below.

Table 14. Forms of obtaining regular soybeans (\%)

\begin{tabular}{|c|c|c|c|}
\hline Own production & & & - \\
\hline Outsourced production & & & 100 \\
\hline Spot market & & & - \\
\hline $\begin{array}{l}\text { Relational suppliers } \\
\text { contract) }\end{array}$ & (no & formal & - \\
\hline
\end{tabular}

Suppliers with formal contracts $\quad 100 \%$ 
Korin's major concern relative to soybeans is its price volatility: in general, it tends to vary on average between $10 \%$ to $40 \%$ per year; considering both the Brazilian and the international market (see Figures 8 and 9). Moreover, said variation is not uniform (both on the up-side and on the down-side).

Figure 8. Soybean price and volatility in Brazil

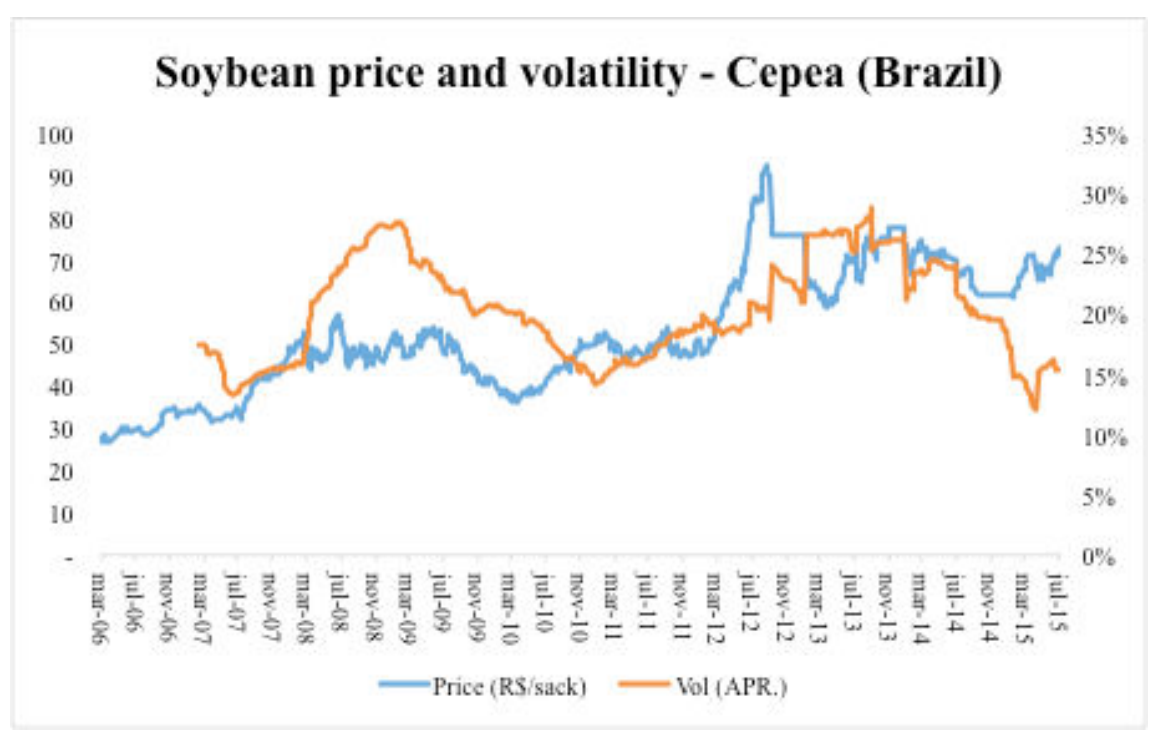

Source: Based on data retrieved from Cepea (2015)

Figure 9. Soybean price and volatility in international markets.

\section{Soybean price and volatility - The World Bank}

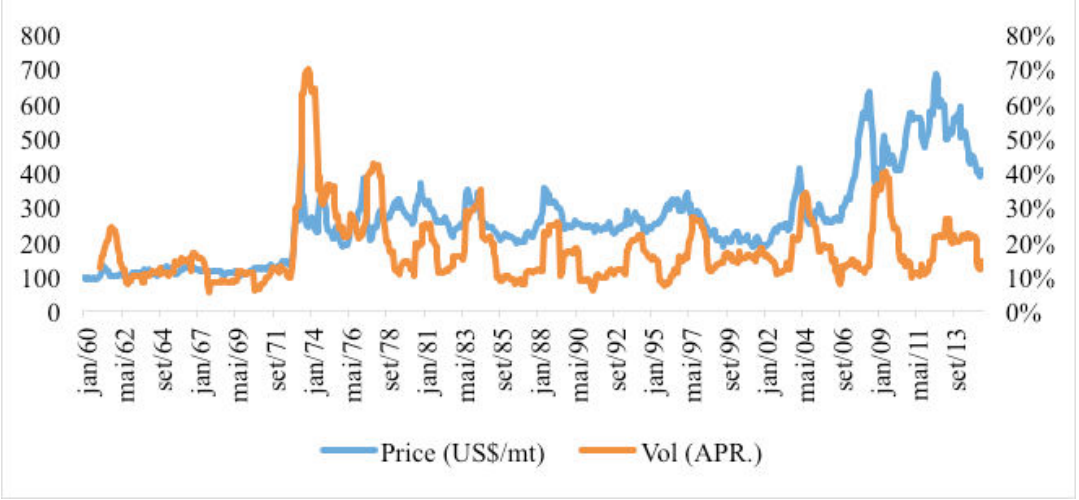

Source: Based on data retrieved from The World Bank (2015)

What is noteworthy in these figures is that soybean prices seem less volatile in Brazil than in the international market. However, it also seems like the price volatility behaves in a much more random way in Brazil relative to that in international markets: verify in Figures 8 and 9 
above that while in international markets one can notice something resembling a 2-year cycle of ups-and-downs, in Brazil, there does not seem to be eye-ball identifiable pattern in these variations. But despite this finding, of course, both markets should be highly correlated, given that we are considering the same commodity, which can be imported and exported across different markets.

In addition to that, one must remember these prices are the result of a balance between supply and demand in terms of quantities: whenever there is a shortage (demand > supply), prices go up and vice-versa.

Given that the company acquires a relatively large quantity of this input, and considering the impact of the price volatility of said commodity on the costs of producing both eggs and poultry; it is imperative that it devises mechanisms to deal with the uncertain market conditions leading to this highly volatile scenario.

One of these mechanisms consists of procuring regular soybeans by means of formal contracts, rather than relying on market relationships. By doing so, Korin both secures the delivery a given amount of the product and also safeguards against rapid soybeans appreciations. Said differently, by formally contracting, the firm is able to smooth the price paid for soybeans in an average range that is neither too high not too low; but more predictable.

\subsection{Main reasons for procuring regular soybeans by means of formal contracts (hybrid arrangements): asset specificity and uncertainty}

\subsection{Asset specificity}

Because Korin obtains and uses regular soybeans, it is a commodity that can relatively easily be found on the market. It does not require any special care and therefore, the level of asset specificity is very low. Nevertheless, the company turns to formal contracts instead of the spot market because it is important that it guarantees the necessary quantities at the right price to keep its cost low, as mentioned before in this paper.

110 Predicting plural forms and diversified organizational arrangements with the combination of asset specificity and uncertainty: a case study in brazil 


\subsection{Uncertainty}

Market uncertainty is relatively high for soybeans in general. This is because there is a high volatility in its price, as shown in Figures 4 and 5 presented before. Of course, price volatility does not come alone: it is correlated with volume volatility and therefore, market volatility in general is significant for regular soybeans.

\subsection{Organizational arrangements decision}

Korin gets regular soybeans with non-plural forms because this product requires low levels of asset specificity and considerable uncertainty. Therefore, this transaction would fall outside the grey zone in our model. However, differently from our prediction, it turns to hybrid arrangements and not to the spot-market.

\subsubsection{Plural forms - the grey zone}

From this section forward, we will show three sub-cases for which plural forms are used to procure inputs (antibiotic-free eggs, organic corn and regular or standard corn).

These arrangements are different relative to the 'standard' hybrid zone in Williamson's (1985) model because they typically involve the simultaneous adoption of more than one alternative arrangement. For instance, they may involve the simultaneous use of the spot market and the hierarchy. Or they may combine different arrangements that are typically hybrid. They are a mixture of white in markets and black in hierarchies (Lewin-Solomons, 1998).

The hybrid zone, in Williamson's (1985) model, in turn, concerns the use of a unique typology of hybrid arrangements; for example, a single type of formal contract. They are a uniform shade of grey composed of the white attributes in markets and the black attributes in hierarchies (Lewin-Solomons, 1998).

We will show, in the next subsections, that the subcases under review are of the first type, combining different arrangements simultaneously. Indeed, Korin gets antibiotic-free eggs and 
regular and organic corn through plural forms because the levels of asset specificity and uncertainty affecting these transactions place them inside the grey-zone in our model.

\subsubsection{Antibiotic-free eggs}

The sale of eggs accounts for 9\% of the Korin's revenue, corresponding to the second product in terms revenue share (it is only surpassed by that of poultry). Just like in the case of poultry, the production of organic or of antibiotic-free eggs requires differentiated techniques. Similarly to the production of poultry, the birds are raised free within a delineated area in the farm, where they can move as they like and even catch some daylight. This requires much more labor-force than the conventional process.

Also, special care is taken to assure the well-being of these animals, including adopting a much lower density of animals per square meter relative to the conventional production practices and not pecking them. Additionally, these animals' feet are not bruised because they are not kept in cages.

Add to these particularities the fact that these birds are fed with a special mixture of corn, soybeans and soy chaff that is freshly produced in order to avoid the oxidation of oils that render the animals sick. Finally, it is worth mentioning that when these birds do get sick, they are treated with natural drugs and do not receive any type of antibiotics or other chemicals.

Despite all the specificities required to produce antibiotic-free eggs, Korin obtains them by combining some in-house production with different types of contracts, as shown in Table 15 , below. 
Table 15. Forms of obtaining antibiotic-free eggs (\%)

\begin{tabular}{cc}
\hline Own production & $23 \%$ \\
Outsourced production & $77 \%$ \\
Spot market & - \\
Relational suppliers (no formal & \\
contract) & \\
Suppliers with formal contracts & $100 \%$ \\
Supplier type 1 & $29 \%$ \\
Supplier type 2 & $14 \%$ \\
Supplier type 3 & $57 \%$ \\
\hline
\end{tabular}

Besides vertical integration ( $23 \%$ of the total production), there are three types of formal contracts for the acquisition of antibiotic-free eggs, differing mainly in the degree of autonomy granted to producers. And this depends on the extent to which said producers control the supply chain.

For instance, 29\% of Korin's antibiotic-free eggs come from its first producer, controlling the entire production process and delivering the eggs clean, classified, sanitarily inspected and packaged with Korin's brand (see figure 10A). 14\% of Korin's antibiotic-free eggs come from one producer, which delivers the eggs to be cleaned, classified, sanitarily inspected and packaged by Korin, who then sells them (see Figure 10B). Finally, the vast majority of Korin's antibiotic-free eggs come from three producers who are almost integrated to the company. This is because they do not control the production process at all, but merely provide the workers and their physical structure required to produce these eggs. Korin, in turn, provides its own hens and technical assistance to these farmers (see Figure 10C). 
Figure 10. Schematic representation of the stages of the egg supply-chain which are controlled by Korin (green dotted line) and by its suppliers (black dotted line).

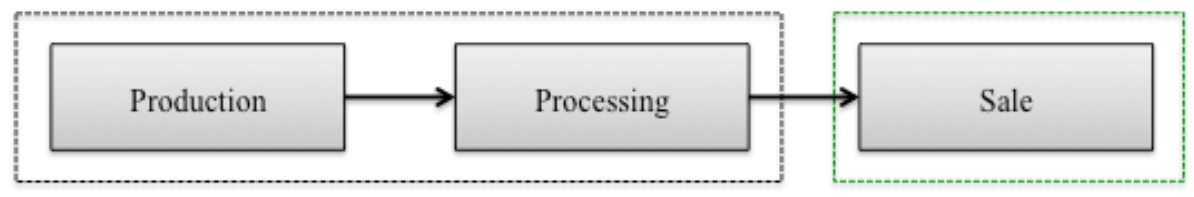

A

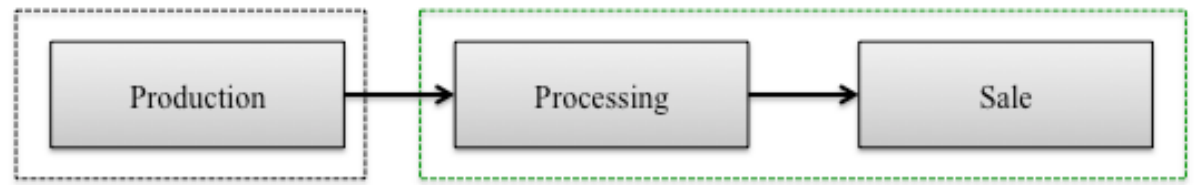

B

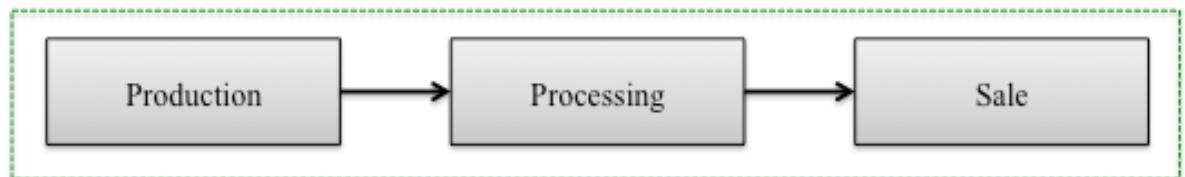

$\mathrm{C}$

Such diversity in terms of contracts and of control is not by chance. In fact, finding suppliers that are willing to adapt their production methods to these special requirements is by no means an easy task.

In its very beginning, Korin used to produce $100 \%$ of its eggs in-house. And what is noteworthy was that they did not, at the time (1996), dominate the technology of raising birds free in the farm. For this reason, the eggs came from hens that were kept in cages, just like in the regular case. This is why they decided a year later to stop producing them and therefore, quit distributing eggs. After all, accounting for the animals' well-being is part of Okada's philosophy and developing an alternative technology would require large investments which were not in the company's priorities at the time.

It was only in 2002 that Korin was able to identify and contract with an egg-producer that had developed the Natural production process (or technology), with the guidance of the Mokiti Okada Foundation. And it consisted of raising the birds free, as described at the beginning of this section.

Said producer remained the sole supplier of antibiotic-free eggs until the end of 2007, when

114 Predicting plural forms and diversified organizational arrangements with the combination of asset specificity and uncertainty: a case study in brazil 
Predicting plural forms and diversified organizational arrangements with the combination of asset specificity and uncertainty: a case study in brazil

more consumers started to become aware and concerned with organic or other special types of fresh food. Besides the growing demand, requiring a larger production scale, the increasing awareness with the origin of organics or antibiotic-free food demanded that these eggs became certified. And both increasing scale and meeting the requirements in order for the product to be certified demanded that the supplier invested a lot in its production, in a way that he was not yet ready to commit.

This is why, at the time, Korin became obliged to produce some of the eggs in-house (and therefore, turn to plural forms): it needed to gain scale and quality control to become certified. And what is interesting is that after successfully completing both challenges, the prior supplier also decided to invest to become certified and therefore, Korin then benefited from having enough certified eggs to meet the growing demand.

It is relevant to mention that the relationship with said supplier remains to date $(29 \%$ of the eggs now come from its facilities) and that this is the contracted supplier that controls the most significant part of Korin's egg supply chain (Figure 10A).

Nonetheless, over time, demand for organics or antibiotic-free eggs continued growing; even though in Brazil it can still be regarded as a niche market. In fact, these eggs represent less than $0.15 \%$ of the entire egg market (including regular eggs). But, when considering the size of this market - about 60,000,000 eggs per month - the volume attributed to the antibioticfree variety is not that small. Specially considering the technological challenge of producing them.

This growing demand led Korin to contract with 4 other suppliers, whom it managed to convince to adopt the special production process; even though only one of these managed to control the production itself (such supplier is represented in Figure 10B), except for the processing unit which required large investments to be done. The other three needed to receive technical assistance and the hens themselves, mainly because they did not master this different way of producing (they are represented in Figure 10C).

The question that yet remains unanswered is: given that it could convince other suppliers to produce antibiotic-free eggs (i.e., it is not anymore a matter of scale), why is Korin 
maintaining in-house production? In fact, what we have not mentioned so far is that ever since the beginning, Korin faced many difficulties in measuring its suppliers' productivity and therefore, developing objective measures to remunerate them for their product.

To put it differently, it was hard to determine the marginal productivity for which suppliers should be paid. And producing some eggs in-house assists Korin in this endeavor. This is because hens do not always produce the same amount of eggs along their life-cycle. Typically, there is a sharp growth in terms of productivity as the animal matures, until it reaches the peak. Finally, as it ages, productivity declines until the hen becomes so unproductive that it needs to be sacrificed and sold as meat (which is typically worse in terms of quality than chicken). An approximation of this curve is illustrated in Figure 11, below.

Figure 11. Typical egg productivity for regular techniques.

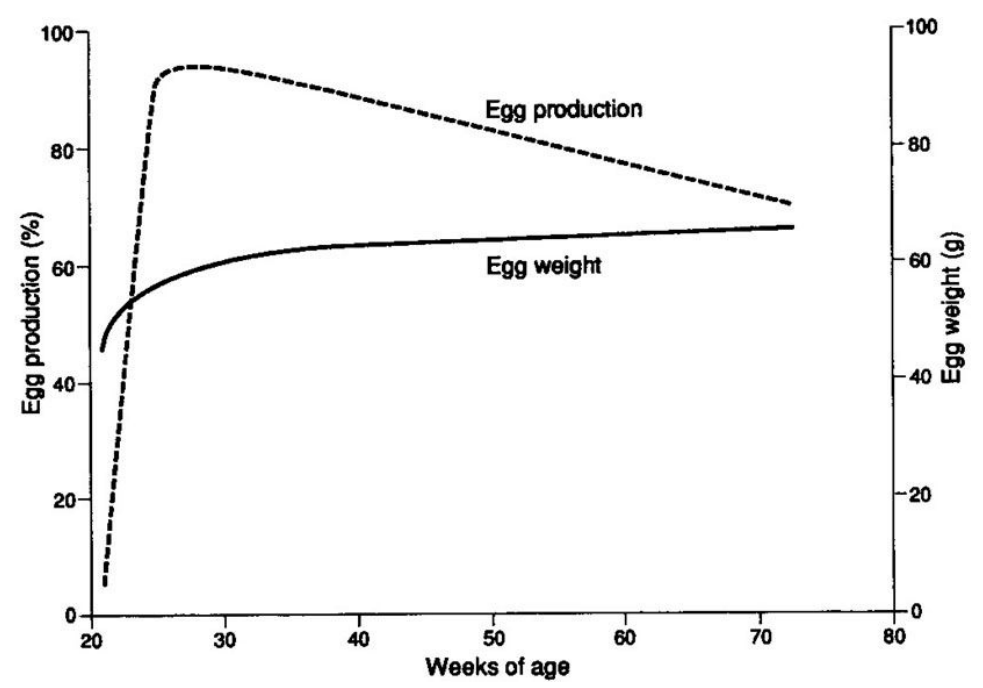

Source: Retrieved from Raising Chickens for egg production by Jacob (2015)

Of course, the productivity does not only depend on the age of the bird; but also on other factors. The chicken's breed and the way it is fed are just a few examples of the variables determining productivity. However, we stress the age of bird as an important determinant because it provides us with an easier approximation for the shape of the production curve (like the one in Figure 11).

Therefore, by producing in-house Korin first gained knowledge about how to monitor its suppliers' productivity, especially since they were both using similar production techniques 
and chicken breeds. It also knows the stage of the lifecycle where each supplier is operating and finally, it can use this information to better assist new suppliers. For instance, it can confidently tell new suppliers that raising 10,000 chickens is not as profitable as raising 2,000 at a time because they can diversify the stages in the lifecycle and get an average productivity that is more uniform. But, above all, by gaining information on the productivity, Korin can better estimate its suppliers' costs and therefore, offer them compensation accordingly.

\subsection{Main reasons for procuring regular soybeans by means of formal contracts (hybrid arrangements): asset specificity and uncertainty}

\subsection{Asset specificity}

As mentioned before, the production of antibiotic-free eggs requires quite high levels of asset specificity. This is mainly due to the differentiated production technique that is required in order to raise free birds, to feed them and to treat them when they are sick. Also, it is mandatory that investments be made in order to obtain the certification that is so valued by consumers; and to realize the inspection process that is required by the Ministry of Agriculture in order for the product to be sold. However, differently than poultry, there is neither such a strict scale constraint nor is there the need for high dedicated infrastructure investments and this is why the level of asset specificity is not dedicated, but high.

\subsection{Uncertainty}

Uncertainty is very high in the production of antibiotic-free eggs. First, there is technological uncertainty related to the differentiated production process. As mentioned before, developing said technology was by no means an easy task, and neither was it convincing suppliers to adopt it. Furthermore, maximizing productivity according to the parameters that determine it is also not as trivial as it may seem. There can be variations according to the breed or to the way birds are fed, that are still unknown and need to be experimented for.

Second, there is high performance assessment uncertainty in the case of antibiotic-free eggs because it is very hard (if not impossible) to measure the suppliers' marginal productivity 
and thus determine their cost. To begin with, it is impossible to determine at the outset the lifecycle stage on which each of the suppliers' hens are. And therefore, it is hard to determine whether or not the supplier is lying about its cost. This is why monitoring and control mechanisms are so important: they signal to the supplier that Korin has information to estimate their productivity, even though such estimation is largely approximated. This prevents suppliers from opportunistically declaring to be in an early stage in Figure 11, as to sell a smaller quantity for a higher price (because they can't always be in the early stage and because Korin can mimic their production).

\subsection{Organizational arrangements decision}

\section{Organizational arrangements decision}

Korin turns to plural forms to procure antibiotic-free eggs because this transaction is affected by considerable uncertainty and requires intermediate levels of asset specificity. Therefore, it would be placed in the grey-zone in our model. As we predicted, the procurement of eggs is made through plural forms.

\subsubsection{Regular corn}

Regular corn is crucial to Korin because it is used to feed chicken both for poultry and for eggs; even though it enters into the mixture in a smaller proportion relative to the organic variety (according to the ongoing regulations in Brazil, the mixture that is used to feed organic or antibiotic-free chickens may contain regular corn or soybeans if they do not surpass $15 \%$ of the total weight of feed and as long as they are not genetically modified). Nevertheless, its price is an important component of Korin's cost (corn and soybean combined correspond to $75 \%$ of the cost of feeding the animals) and having this product available becomes crucial for the company's operation. After all, it cannot feed the animals without corn, even if it can manage to substitute the organic type for the regular variety, albeit at a higher cost. 
Predicting plural forms and diversified organizational arrangements with the combination of asset specificity and uncertainty: a case study in brazil

It is worth mentioning that although it is merely regular corn, it is not as trivial as it may seem because in order to feed the special animals, the quality of the corn becomes a crucial asset ${ }^{36}$. This means that Korin's chicken cannot be fed indifferently with any regular corn, but solely with high quality variety of the product.

To this end, Korin obtains its regular corn according to Table 16 presented below.

Table 16. Forms of obtaining regular corn (\%)

\begin{tabular}{|c|c|}
\hline Own production & - \\
\hline Outsourced production & $100 \%$ \\
\hline Spot market & - \\
\hline $\begin{array}{l}\text { Relational suppliers } \\
\text { contract) }\end{array}$ & $99.8 \%$ \\
\hline Local producers - type 1 & $4 \%$ \\
\hline Local producers - type 2 & $5 \%$ \\
\hline Local producers - type 3 & $40 \%$ \\
\hline Cereal companies & $50 \%$ \\
\hline Suppliers with formal contracts & $<0.1 \%$ \\
\hline Futures market & $<0.1 \%$ \\
\hline
\end{tabular}

What is noteworthy is that regular corn is outsourced mostly by means of different relational contracts, although a very small quantity comes from occasional formal contracts with large suppliers or from the futures market. The main differences in terms of relational contracts are associated with the type of agent the company is dealing with (local producers vs. large cereal companies) and with the way by which the sale occurs (local producers types 1,2 and 3).

First, and most intuitive of all, the relationship with large firms and with small local producers is naturally different and therefore, the specificities of these relational contracts differ accordingly. What is most interesting within these differences is that the local producers can sell their corn in three different ways, as shown in Figure 12.

\footnotetext{
${ }^{36}$ Corn is prone to developing fungi and bacteria and the affected grains present very low quality (University of Illinois, 2012). The problem is that the low quality corn is harmful for the chickens' health, and therefore, cannot be used to feed them.
}

Predicting plural forms and diversified organizational arrangements with the combination of asset specificity and uncertainty: a case study in brazil 
Figure 12. Ways of obtaining corn from local suppliers

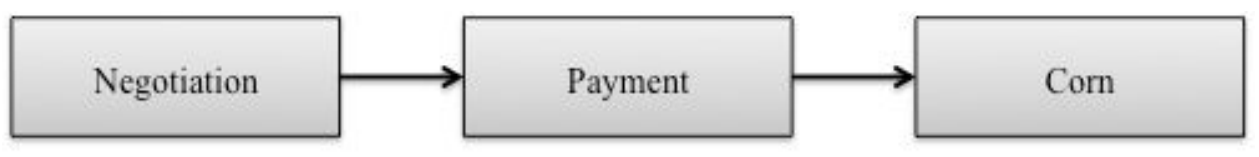

A

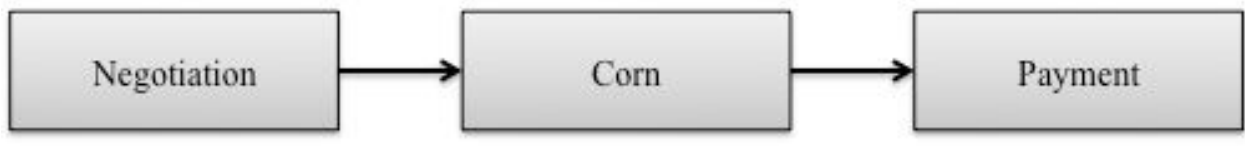

B

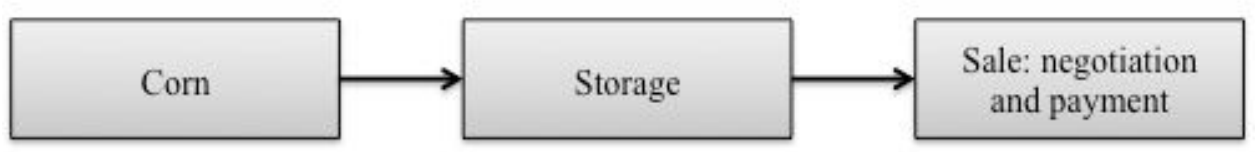

$\mathrm{C}$

In the first of these (Figure 12A), Korin pays for the corn before it is ready to be sold, according to price and quantities that are agreed upon beforehand. It therefore only receives the corn later, when it is ready. The second way of commercializing corn differs from the first in that the payment does not occur when the relational contract is agreed upon, but when the corn is actually received (Figure 12B). However, both price and quantity are fixed beforehand, when the agreement is made. Finally, the most frequent way of obtaining corn from local suppliers consists more of a partnership than of a relational contract in its strict sense.

In that respect, Korin keeps its suppliers' corn in its own storage facilities, without buying it. In fact, it only buys this corn whenever each supplier decides to sell it and what is paid for it is agreed upon at the time the sale occurs, according to the daily market price and conditions (Figure 12C). Of course, this latter way of buying corn is more costly because keeping the corn requires space (out of scarce land) and adequate conditions such that the production is not damaged (i.e., special facilities are required for keeping $\operatorname{corn}^{37}$ ); but it helps guarantee the

\footnotetext{
${ }^{37}$ Corn is likely to be affected by fungi and bacteria if not correctly stored. This is favored by high temperatures and especially by moisture, requiring that special care be taken to avoid it. Some good practices include periodic inspections on the product (as to remove those grains that developed mold) and on the storage units (cracked ones favor the appearance of fungi and bacteria) (University of Illinois, 2012).

120 Predicting plural forms and diversified organizational arrangements with the combination of asset specificity and uncertainty: a case study in brazil
} 
Predicting plural forms and diversified organizational arrangements with the combination of asset specificity and uncertainty: a case study in brazil

supply of the product. Evidently, it is implied that Korin will not keep the corn unless it knows it won't be sold by these suppliers elsewhere.

And this is a win-win agreement because on the one hand, it guarantees the supply of product and on the other; it allows local producers to freely speculate on the price of the product because they can decide when they want to sell, since they can now keep the product in safe conditions.

It is important to note that there is a lot of volatility in corn price index ${ }^{38}$, as shown in Figure 9 (volatility varied, on average, between $15 \%$ and $25 \%$ per year). Of course, this index does not reflect price differences relative to the quality of the product, but it illustrates, in a general way, how prices varied over time. Thus, one can confidently assume that even the price of the high quality corn varied this much over the same period.

Figure 13 - Daily nominal corn price index in US Dollars.

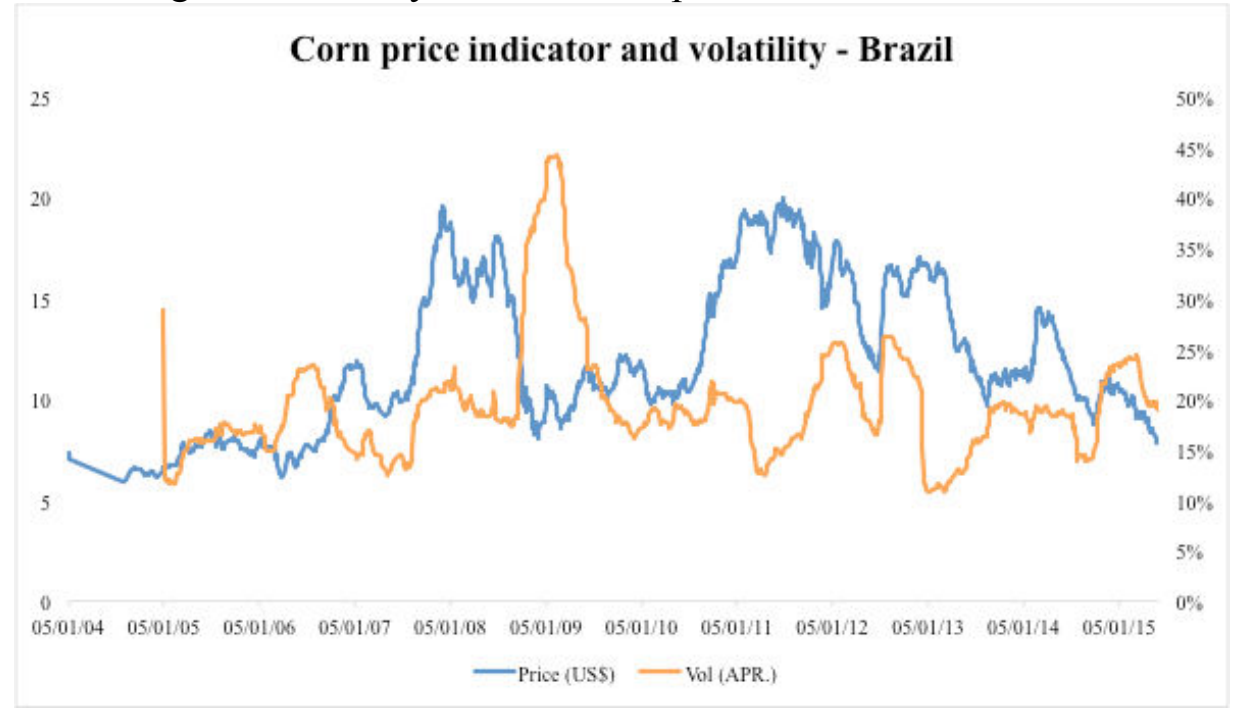

Source: Based on data retrieved from Cepea (2015).

And although large cereal companies might perform sophisticated financial analyses that would allow them to better "predict" corn prices, the same cannot be said for small local producers, who rely mostly on their intuition and experience to price their products (even though they can obtain some information on this market from secondary sources, their ability

\footnotetext{
38 The domestic market is much more important for corn because there is very low added value and transportation costs are significant. Therefore, we have collected data for the domestic market only.
} 
to properly use it is limited). This might help explain their preference for the third way of selling corn to Korin (Figure 12C).

Regardless of this fact, market volatility proves to be a threat to Korin because, as already mentioned, both corn and soybeans prices correspond to $75 \%$ of the company's cost of feeding the animals. In that respect, variations in the market price of this input lead to important cost increases (or reductions). This is why it is imperative that Korin devises mechanisms to neutralize the high market volatility.

Add to this the fact that high quality corn cannot be as easily obtained on the market as the mainstream variety, turning to organizational mechanisms that guarantee the supply of the product is as crucial as those related to prices.

\subsection{Main reasons for procuring regular soybeans by means of formal contracts (hybrid arrangements): asset specificity and uncertainty}

\subsection{Asset specificity}

One can infer from the information provided in this case that asset specificity is low for regular corn. Because Korin does not make use of the mainstream commodity, but of the high quality variety of the product, the level of specific assets involves is not zero, but somewhere close to $\mathrm{k}_{1}$ in our model. This implies that suppliers cannot be as easily replaced as in the commodity case, and therefore, more complex organizational solutions relative to spot markets become relevant.

\subsection{Uncertainty}

Market uncertainty is quite high for regular corn of high quality. First, as mentioned before, there is significant price volatility for regular corn. And this variation is most certainly present in the high quality variety market. Also, it is worth mentioning that price volatility might induce quantity volatility because when prices are low, producers might stop growing corn and start growing another commodity that can grow under the same circumstances (supply).

122 Predicting plural forms and diversified organizational arrangements with the combination of asset specificity and uncertainty: a case study in brazil 
Conversely, when the price is high, the market tends to substitute the purchase of soybeans for that of corn (demand). Therefore, there is both price and quantity volatility.

\subsection{Organizational arrangements decision}

Korin turns to plural forms to procure regular (standard) corn because this transaction involves intermediate levels of asset specificity and is affected by considerable uncertainty. Therefore, as predicted, it falls in the grey-zone in our model.

\subsubsection{Organic corn}

Just like regular corn, organic corn is used to feed Korin's chickens; to obtain poultry or eggs $(75 \%$ of the feed is composed of organic corn and organic soybeans). However, differently than in the previous case, it is the main component of their feeding and cannot be substituted for the regular variety. Therefore, it is imperative that the firm obtains enough organic corn to satisfice its needs. As of 2014, Korin consumed over one thousand tons of the product each month, considering both the organic and the regular varieties (Demattê Filho, 2014).

Moreover, because it is the most important raw-material to produce the company's main products, it is crucial that the prices paid for it do not exceed the cost baseline established by the firm. Otherwise, it loses competitiveness and potentially market share. After all, by no means does Korin obtain a small quantity of the product: it must feed enough animals to yield a production of at least 9 thousand tons of chicken and 7 million eggs per year (Avicultura Industrial, 2011).

Because of the relevance of this product, Korin obtains it in a different way relative to the regular variety and the main distinction consists of its own production as shown in Table 17 below. 
Table 17. Forms of obtaining organic corn $(\%)$

\begin{tabular}{cc}
\hline Own production & $15 \%$ \\
Outsourced production & $85 \%$ \\
Spot market & - \\
Relational suppliers (no formal & $30 \%$ \\
contract) & \\
Suppliers with formal contracts & $70 \%$ \\
Cereal companies & $100 \%$ \\
\hline
\end{tabular}

It is also interesting to note that whereas the regular variety of corn is mainly obtained by means of relational contracts, its organic version is mainly bought with formal contracts with cereal companies in Brazil. These contracts are signed for each harvest and the price of the organic corn is established ex-ante as roughly $30 \%$ more than that of regular corn.

It is interesting to mention that Korin negotiates with its suppliers through the purchase pool it is part of. Such pool, composed of many companies that require organic corn for their production, allows them to obtain a better position in the negotiation, given that all the companies together are willing to acquire a very large quantity of the product.

Despite this fact, Korin's own production is cheaper than the price paid to contracted parties. This may be due to two reasons. First, the higher price must include the producers' markup, which is absent in the case of the corn produced in-house. Second, producing organic corn is not as trivial as it may seem at the outset. It requires specific knowledge to enable a good productivity and Korin does master it. In fact, while the yield of conventional corn is on average that of 10 to $12 \mathrm{~kg}$ per hectare that of the organic variety is roughly half.

The lower productivity of the organic corn can be attributed mainly to two factors. First, organic corn grows together with other useless bushes and therefore, this not only reduces the average yield per hectare but also requires that special care be taken to ensure that most of the investments will be destined to corn rather than these useless bushes. Second and relatedly, the organic production of corn requires more labor force than the conventional variety, mostly because of the bushes and the special care that is needed to separate it. 
Predicting plural forms and diversified organizational arrangements with the combination of asset specificity and uncertainty: a case study in brazil

Because of these particularities, determining the average productivity at the outset is by no means an easy task. This is a major concern to the company because it should pay its suppliers according to their productivity. And in the absence of control mechanisms, these suppliers can easily and opportunistically declare a lower productivity. This is why, according to Korin, its own production is so strategic: first, it allows to better estimate its suppliers' productivities because it can get more information; second, as already mentioned, it is cheaper than the corn that is bought; and finally, it guarantees a minimum quantity of the product.

But if the in-house production of organic corn is so strategic, why does Korin not produce more of it? The first answer is that agricultural products cannot always be produced as desired. For instance, corn does not grow uniformly all year around, but at certain times. And these periods vary according to region of Brazil where it is being produced. While in Sao Paulo it grows only once a year, in the southern region it grows twice and at different times ${ }^{39}$.

This requires that the company buy the product from other regions when it is not being produced in Sao Paulo ${ }^{40}$. And this becomes even more relevant because organic corn cannot be stored like the regular variety. It can only be kept for about two months because no chemicals can be used in the storage facility to guarantee the integrity of the product. This fact also requires that Korin devises mechanisms to guarantee the supply (both in terms of quantity and of price) of such a strategic input, for instance, by adequately contracting with its suppliers.

Second, even if harvest were not a concerned, Korin would not have as much productive land as necessary to produce all of its corn. Finally, because of the strategic character of the organic corn to the company, it cannot risk to satisfy all of its needs from a single producer because there could be diseases or unforeseen climatic variations that could cause it to lose the entire production.

\footnotetext{
${ }^{39}$ Brazil is very large, with a surface of $8,515,767.049 \mathrm{~km}^{2}$ (IBGE, 2013). There are six different types of climate in the different regions of the country and therefore, the production of distinct commodities is favored in each of these regions and at different times of the year.

${ }^{40}$ Korin has no incentive to buy from other regions except in extreme necessity because of high transportations costs.
}

Predicting plural forms and diversified organizational arrangements with the combination of asset specificity and uncertainty: a case study in brazil 


\subsection{Main reasons for procuring regular soybeans by means of formal contracts (hybrid arrangements): asset specificity and uncertainty}

\subsection{Asset specificity}

Asset specificity is intermediate because, as mentioned in this case, not only does the corn need to present high quality, but it also requires a different production technique because of its organic origin. The difference includes more labor force (and therefore, higher cost), a different technological process (separating the corn from the bushes and not using pesticides and chemicals) and a lower average productivity. Finally, organic corn cannot be stored for as long as the regular corn. Moreover, because the product cannot be stored for more than 2 months, temporal asset specificity is also present to increase the overall level of this variable.

\subsection{Uncertainty}

Both market and performance assessment forms of uncertainty are relatively high for organic corn. First, just like in the case of regular corn, market volatility is significant. But in this case, it becomes more relevant because of the storage restriction, which prevents its suppliers from storing the product to deal with this volatility. Moreover, there is also a matter of performance assessment that increases the magnitude of the combined uncertainties in this case. The problem here is that Korin cannot easily assess its suppliers' productivity because it depends on a number of variables. To name a few, depending on how much the supplier invests in labor force, it will get a higher or lower productivity; depending on how well it masters the organic technology it will get more or less corn per hectare; and so on. Both sources of uncertainty become more of an issue to Korin because it requires a very large quantity of organic corn and hence becomes more vulnerable to the impact brought by these types of uncertainty.

\subsection{Organizational arrangements decision}

Korin gets organic corn my means of plural forms because this transaction involves intermediate levels of asset specificity and is affected by high uncertainty. Therefore, this 
transaction falls in the grey-zone in our model and, as predicted, is carried out with plural forms.

\subsubsection{A comparative perspective and discussion}

We saw that Korin obtains a number of products either by means of non-plural or of plural forms. Moreover, as stressed in each of the subcases composing the Korin case, there are distinct levels of asset specificity and of uncertainty affecting the procurement of each product related to the different subcases. Finally, as already discussed, different types of uncertainty affect each product.

Therefore, we present next a comparative perspective of all the sub-cases herein discussed, taking care to address asset specificity and uncertainty. We conclude our discussion with a confrontation of these empirical data with our theoretical model with regard to the selected organizational arrangements.

\subsubsection{Asset specificity}

Asset specificity could be found in different levels, depending on the product at stake and on the techniques required to produce it. In Table 13, below, we classify the levels of asset specificity for each of the sub-cases, representing more asset specificity with a larger number of ' + ' and less asset specificity with a smaller number of ' + '.

\begin{tabular}{ll}
\multicolumn{2}{c}{ Table 18. Levels of asset specificity } \\
\hline Product & Asset specificity \\
\hline Regular soybeans & + \\
Regular corn & +++ \\
Organic corn & ++++++ \\
Antibiotic-free eggs & ++++++++ \\
Poultry & +++++++++++ \\
\hline
\end{tabular}

In that respect, we showed first that regular products (standard corn and soybeans) present a much lower level of asset specificity than the organic or the antibiotic-free varieties. They are 
either commodities or slightly differentiated varieties of both corn and soybeans that do not require specialized technologies or other distinct production techniques. However, because quality is a major concern for corn, we argued that its level of asset specificity is higher than that for regular soybeans, although still much lower than that of the organic variety.

This is because the organic production of corn requires much more specialized knowledge as to enable productivity closer to that of the conventional product. To this end, not only are technological skills needed, but also, more labor-force and the ability to adequately match supply and demand within a short period, since the product cannot be stored for more than two months (whereas conventional corn can be kept in proper warehouses for about a year).

These specific investments are nevertheless lower than those required to produce both eggs and poultry. As we have stressed throughout this case, organic or antibiotic-free birds are raised much differently than regular animals; and are specially fed with a mixture of corn, soybeans and soy chaff. And this, of course, requires specialized knowledge related to these special techniques. Nevertheless, because poultry requires large-scale production to become competitive and demands very high investments for the slaughterhouse; we can confidently consider its level of asset specificity to be higher than that of the eggs (or even dedicated); although high asset specificity is present in both cases.

\subsubsection{Uncertainty}

High uncertainty surrounds the procurement of all the products discussed, albeit of varying type (market, technological, performance assessment) and of relative intensities. In that respect, we must stress that we did not attempt to quantify uncertainty, but rather to qualify the dominant type for the different sub-cases so as to get a better understanding of the circumstances under which each transaction takes place. However, differently than in the case of asset specificity, it was much harder to establish the relative intensity for uncertainty because this is a much more subjective variable, which we captured through assessments made in our interviews. Nevertheless, we make an effort to compare these relative intensities, according to our understanding of the cases based on the interviews, documents, and available data (e.g., volatility of prices etc.) In Table 14, below, we summarize our classification of the 
levels of uncertainty, using a larger number of ' + ' to represent more uncertainty and a smaller number of '+'to represent less uncertainty.

Table 19. Levels of uncertainty

\begin{tabular}{ll}
\hline Product & Uncertainty \\
\hline Regular soybeans & +++++ \\
Regular corn & +++++ \\
Organic corn & +++++++ \\
Antibiotic-free eggs & ++++++++++ \\
Poultry & ++++++++ \\
\hline
\end{tabular}

First, regular soybeans and corn present similar levels of high market uncertainty, given that these commodities are subject to high price volatility. Higher uncertainty is present in the procurement of the organic variety of corn. Not only is it subject to market volatility like the regular variety of the product, but also this uncertainty becomes more of an issue both because organic corn cannot be stored and therefore, price speculation becomes highly disfavored (the sale has to occur soon) and because the required quantity of organic corn is much larger that of its regular variety. Moreover, because Korin cannot assess their suppliers productivity because it depends on a number of variables related to the suppliers' production process, it is hard to precisely determine the right payment. Therefore, there is also high performance assessment uncertainty in the procurement of organic corn and this is why we consider the overall level of uncertainty for this product to be higher than that of the regular variety.

A similar level of uncertainty can be attributed to the poultry case. As mentioned before, the chickens are fed with a mixture of corn, soybeans and soy chaff (both organic and regular); which represent $75 \%$ of the cost of feeding the animals. Therefore, the market volatility of both corn and soybeans directly determines the volatility of the cost of the product, and therefore, introduces market uncertainty in the supply side of the procurement of poultry. Market volatility on the demand side for poultry is expressed in terms of the price fluctuations of this product in the global market. Therefore, once we add supply and demand market volatility, we get high market uncertainty. 
Finally, the procurement of antibiotic-free eggs is surrounded by the highest level of uncertainty, among all the products discussed in this case. This is because, as already mentioned, mastering the technology that is necessary to produce these eggs is by no means a trivial endeavor. Indeed, developing said technology was not an easy task, and neither was it to convince suppliers to adopt it. Furthermore, maximizing productivity according to the parameters that determine it is also not as trivial as it may seem. There can be important variations according to the breed or to how the birds are fed, factors that are still not extremely well understood and need to be experimented for. Therefore, technological uncertainty is quite high.

Second, there is high performance assessment uncertainty in the case of antibiotic-free eggs because, as mentioned before, it is very hard (if not impossible) to measure the suppliers' marginal productivity and thus determine their cost. Therefore, once we add high technological uncertainty with high performance assessment uncertainty, we get the highest overall uncertainty.

\subsubsection{An integrative framework and the resulting organizational arrangements}

Considering the levels of asset specificity and of uncertainty discussed in the preceding sessions, as synthesized in Tables 13 and 14 above, we have introduced each of the products examined above in our theoretical model, thus giving empirical content to Figure 5, introduced at the beginning of the chapter. 
Figure 14. An empirical illustration of the integrative framework.

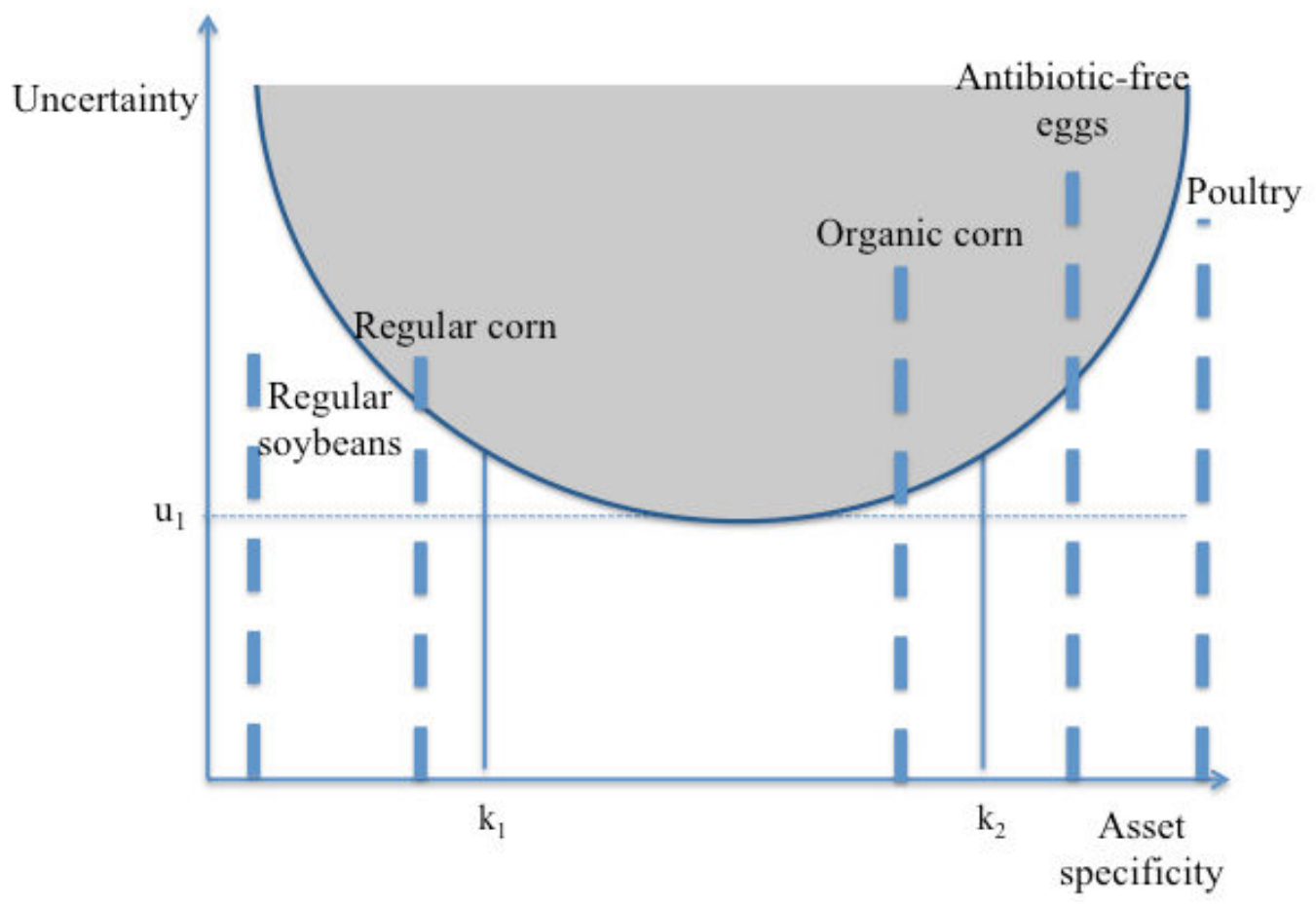

Notice that regular soybeans and poultry are the only products outside the grey zone and they are also the only ones to be obtained by means of non-plural forms. And this is consistent with our model: regular soybeans are obtained exclusively by means of formal contracts because the level of specific investments involved is low and therefore, a very high level of uncertainty would be required in order to outperform this non-plural organizational solution. Nonetheless, and this diverges from our prediction, hybrid arrangements have been used instead of the spot market. One possible explanation for this finding is that Korin is using these contracts to guarantee the supply of a crucial input. Another possibility is that under high uncertainty, more complex governance is needed.

Conversely, the production of poultry involves almost dedicated assets, so that an extremely high level of uncertainty (or even infinite) would be required in order to outperform hierarchy; as discussed in chapter 3. Therefore, this finding is highly consistent with our model.

Between these two pure 'polar' cases, there are three cases in the grey zone: regular corn, organic corn, and antibiotic-free eggs. As predicted, they present intermediate degrees of asset 
specificity (between $\mathrm{k}_{1}$ and $\mathrm{k}_{2}$ or close to them from the left or from the right) and high levels of uncertainty. Thus, their procurement is made by means of plural forms. We can argue, therefore, that these organizational arrangements help Korin to best deal with high uncertainty, at each individual level of asset specificity.

What is noteworthy in these cases, however, is that each of these products is obtained by means of a combination of different organizational arrangements. For instance, organic corn is obtained both internally and by means of formal contracts; whereas regular corn is solely outsourced, mostly with a mixture of different types of relational contracts. Finally, antibioticfree eggs are obtained in a way that is similar to organic corn: part is produced in-house and part is outsourced by means of different types of formal contracts (rather than relational like in the case of the regular corn).

What is also very interesting to see is that each of these products is subject to a different type of uncertainty: while regular corn is subject to high market uncertainty, organic corn is subject to both high market and high performance assessment uncertainties. Finally, antibiotic-free eggs are subject to both high technological and performance assessment uncertainties.

This suggests that the type of uncertainty affecting the transaction at stake might help clarify the heterogeneity of plural forms. But further developments in this respect are yet to come.

\subsection{Final remarks}

In this paper, we provided empirical evidence supporting our theoretical model. In particular, we performed a clinical and embedded case study (Yin, 2003; Baker \& Gil, 2013) of the Korin company to show that the combination of asset specificity and uncertainty might allow predicting when plural forms should or should not be observed for different activities, structured by different transactional attributes, within the same firm.

To this end, we analyzed the procurement of five products, which are either the most important products or the inputs that are required to produce them: regular and organic corn and soybeans, antibiotic-free eggs and poultry.

132 Predicting plural forms and diversified organizational arrangements with the combination of asset specificity and uncertainty: a case study in brazil 
Predicting plural forms and diversified organizational arrangements with the combination of asset specificity and uncertainty: a case study in brazil

We also showed that the combination of asset specificity and uncertainty explains the procurement by means of non-plural forms or of plural forms, depending on the intensities by which each of these variables were present in each sub-case. For instance, both poultry and regular soybeans are procured by means of non-plural forms, albeit in different ways: while Korin contracts for the acquisition of soybeans, it integrated the production of poultry. And although both products are subject to high uncertainty, it is their level of asset specificity that motivated the choice for non-plural forms. As predicted in our theoretical model, and in coherence with the model first introduced by Williamson $(1985 ; 1991)$, goods with very low or very high asset specificity will be procured with non-plural forms, either in market relationships or in-house (respectively), regardless of the level of uncertainty surrounding said transactions.

However, between these two polar cases, plural forms develop, depending on the degrees to which uncertainty and asset specificity were present. We found that regular and organic corn and antibiotic-free eggs were procured by means of plural forms because their sourcing presents intermediate levels of asset specificity and high degrees of uncertainty. And, once again, these findings are consistent with the theoretical model.

What is interesting to note in our findings is that Korin did not choose a unique combination of organizational arrangements to organize the supply of the three products procured by means of plural forms. We conjecture that this could be related to the different levels of asset specificity and of uncertainty that affect said transactions.

We also saw that each of these products is subject to distinct types of uncertainty and this could also help explain why Korin does not select a unique combination of plural forms to organize the supply of different products. But we leave this issue to future studies in this field. In particular, empirically investigating the relationship between the different types of uncertainties and the heterogeneity of plural forms is an interesting and challenging path.

Further efforts must also be made to build more generalizable empirical tests of our theoretical model. As mentioned before, our choice of conducting different case studies in a single company restricts the generalizability of our findings, even when compared to a broader set of case studies. Because on the other hand, we were able to better focus on our 
variables of interest by performing a single embedded case study; on the other hand, we might have found a firm-specific phenomenon. Therefore, further research aimed at generalizing our findings becomes required. In that respect, multiple case studies or quantitative analyzes are interesting candidates to confront our findings.

We should also mention that our embedded case study did not entirely involve independent products, but two independent but related products (eggs and poultry) and their main inputs (regular and organic corn and regular soybeans). This might have introduced biases in our analyses. For instance, Korin only procures corn and soybeans because part of the production of eggs and the entire production of poultry are integrated. Nevertheless, having asset specificity and uncertainty as motivators for the choice of the organizational arrangement for these transactions is not invalidated. This is due the fact that the logic sequence to the decision to procure these inputs is that of how to procure them (i.e., the organizational arrangement).

Despite these limitations, our study is one the first to empirically investigate the interactions of asset specificity and uncertainty as predictors of plural forms and therefore, it sheds new light into the prediction of these organizational arrangements. 


\section{Chapter 5}

\section{Heterogeneous plural forms under uncertainty: an empirical investigation}

\subsection{Introduction}

Plural forms of organization, namely the coexistence of alternative organizational arrangements to organize similar (identical) transactions, have been puzzling organizational economists since the $80 \mathrm{~s}$. This is because the most prominent theories of the firm, namely Transaction Cost Economics (TCE), the modern Property Rights Theory (PRT) and the Resource Based View of the firm (RBV) experience difficulties in explaining plural forms, in their mainstream formulations. And this is especially true for TCE.

The traditional story based on asset specificity in fact does not make room for plural forms in this framework, but, as other scholars have indicated (Dutta, 1995; Parmigiani, 2007; Menard, 2014, our chapter 2), uncertainty might help explain, in association with asset specificity, the existence of plural forms within the TCE framework. This motivated us to develop in our chapter 3 a theoretical model integrating asset specificity and uncertainty to predict plural and non-plural forms, but we remain strictly theoretical in that chapter.

Therefore, in this chapter, we intend to empirically confront our theoretical model and address the following question: Are asset specificity and uncertainty (combined) predictors of plural forms? Although we have found some support for this idea in the case study developed in chapter 4 , we intend to present a more comprehensive dataset to further confront this model.

We also stress in chapter 3 that there is a lot of heterogeneity in terms of the multiple plural form manifestations. Therefore, we are the first hypothesize on chapter 3 on the reasons that would explain the diversity of plural form configurations. In that respect, we associate multiple types of uncertainties (market, technological and performance assessment), given an intermediate level of asset specificity, to different typologies of plural forms ('between' - or 
the combination of different classes of organizational arrangements, 'within' - or the combination of different typologies of hybrid organizational arrangements, and 'combo' - or the combination of the two types described before).

In this paper, we also intend to provide some empirical evidence to confront those hypotheses. Thus, we also intend to provide an answer to the following question: Do different types of uncertainty (considering an intermediate level of asset specificity) motivate the emergence of diversified typologies of plural forms?

To compose our dataset, we survey the procurement of inputs for 24 companies operating in the Brazilian Agribusiness sector, by making use of a 4-point Likert-scale questionnaire. Such questionnaire was built and applied by Menard, Saes, Silva, \& Raynaud (2014) to measure 'ambiguity', 'complexity', 'strategic behavior' and 'asset specificity'; but was never fully used, since they relied solely on the semi-structured interviews that were carried out in the same companies ${ }^{41}$.

However, as we will demonstrate in this paper, some of the questions in Menard et al. (2014) questionnaire can be used as proxies for the three types of uncertainties, as we will define in this paper, even though they do not completely capture them.

Despite the limitations in terms of sample size and in terms of the limited proxies for our variables of interest, we perform an exploratory comparative set of analyzes, and find supportive evidence for our model and hypotheses. These are innovative results, since this paper is the first of its kind to empirically explore the diversity of plural forms and their motivators.

\subsection{Theoretical background}

Our analysis is based on the model we develop in chapter 3, in which we built a framework integrating plural forms (Bradach \& Eccles, 1989) into the Transaction Cost Economics rationale. The basic idea is that the levels of both asset specificity and uncertainty, combined,

\footnotetext{
${ }^{41}$ The questionnaire was not used in Menard et al (2014) because the case studies in plural forms focused only on the main motivation for this choice, while the questionnaire provides a more comprehensive overview of many motivations.
} 
would allow for predictions for plural and non-plural forms. In that perspective, we proposed the model shown in Figure 15.

Figure 15. An integrative model of asset specificity and uncertainty

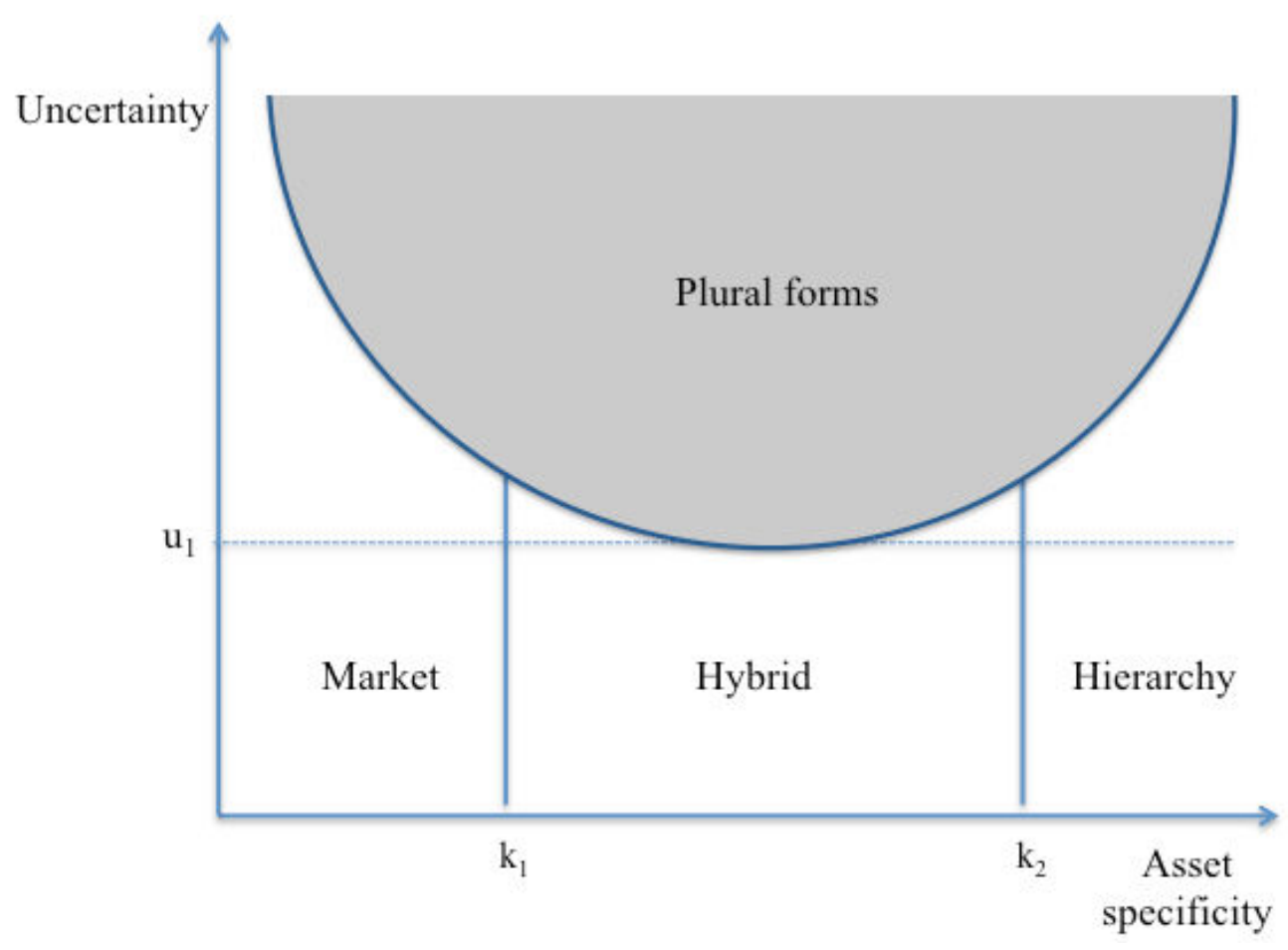

In that model, we follow Williamson (1985) and argue that when the level of uncertainty affecting a given transaction (or set of transactions) is below $\mathrm{u}_{1}$ in Figure 15, only non-plural forms should be observed. Indeed, under this condition of limited uncertainty, the expected organizational arrangements are predicted in a 'standard' transaction-cost minimizing way, depending on the level of asset specificity: for low asset specificity (to the left of $\mathrm{k}_{1}$ ) the spot market should be chosen, for intermediate levels of asset specificity (between $k_{1}$ and $k_{2}$ ) hybrid arrangements prevail whereas for high levels of asset specificity (to the right of $\mathrm{k}_{2}$ ) firms should turn to hierarchies.

However, when the level of uncertainty affecting a given transaction (or set of transactions) is higher than $\mathrm{u}_{1}$, both plural and non-plural forms are expected, depending on the degree to which specific investments are required and to which uncertainty affects the transaction(s) at stake. 
Consider, for instance, a situation in which a given transaction involves a very low level of asset specificity. In this case, transacting parties can be trivially replaced, even when there are unforeseen disturbances. This is why the spot market should prevail, even when the level of uncertainty affecting the transaction(s) at stake is very high (above $\mathrm{u}_{1}$ ). Conversely, when the level of asset specificity is very high (or dedicated), transacting parties are irreplaceable and therefore, in order to economize on safeguards, vertical integration (or hierarchy) becomes the cheapest feasible arrangement to organize such transaction(s), regardless of the level of uncertainty (Williamson, 1991).

Between these two polar cases (between $\mathrm{k}_{1}$ and $\mathrm{k}_{2}$ or close to them from the left or from the right), however, both plural and non-plural forms might develop (for $\mathrm{u}>\mathrm{u}_{1}$ ). The rationale is simple: as the level of asset specificity gradually increases, replacing transacting parties becomes increasingly harder and establishing safeguards becomes increasingly more complex. Typically, in a situation involving low levels of uncertainty (below $\mathrm{u}_{1}$ ), firms would turn to hybrid arrangements (Menard, 2004), but when uncertainty is high $\left(u>u_{1}\right)$, their efficiency is more likely to deteriorate (Williamson, 1991). But, differently than Williamson (1991), we propose that in this case firms would turn to plural forms (the grey-zone in Figure 15).

The basic idea here is that depending on the source of uncertainty (inside or outside the firm), spot markets or hierarchies (the Williamsonian solution to this problem) alone are ill-suited to deal with these hazards. Plural forms, in turn, combine the 'white' attributes in markets with the 'black' ones in hierarchies to compose a 'mix of black and white', rather than the uniform shade of grey in hybrids (Lewin-Solomons, 1998), presenting some characteristics that are similar to hybrids (in the sense that they are neither similar to pure markets nor to pure hierarchies) but that are able to efficiently respond to highly uncertain situations.

Going beyond the prediction for non-plural and for plural forms, we observe that there is a lot of heterogeneity within the 'grey-zone' (Figure 15). To put it differently, we realize that plural forms are not all the same, but they can be composed of a number of different combinations. For example, the make-and-buy type of plural forms typically found in franchise chains (whereby firms usually combine their own stores with franchised units which are contracted for) such as Bob's burgers, a Brazilian fast-food chain combining 89 
company owned stores and 534 franchised units (Portal do Franchising, 2015) is different from the way by which Minerva, a leading company in the Brazilian beef sector procures traced cattle: $65 \%$ comes from relational contracts, $25 \%$ from short-term formal contracts and the remaining 10\% via long-term formal contracts (Menard, Saes, Silva \& Raynaud, 2014). Moreover, these two arrangements (Bob's and Minerva) are different from the way by which Sao Manoel, producing $0.5 \%$ of the entire sugar production of Brazil, procures sugar-cane: $75 \%$ of the sugar-cane is obtained in its own farms, $5 \%$ with relational contracts and $20 \%$ comes from formal contracts (Menard et al, 2014).

In order to explore this variety of plural forms, we group them into three categories and build hypotheses relating different types of uncertainty (or different sources of uncertainty) to each of these multiple types of plural forms. Therefore, we present next three types of uncertainty, which capture the essential dimensions of the concept and the three groups of plural forms. We conclude this section by presenting the hypotheses that relate these two groupings.

\subsubsection{Types of uncertainty}

Following the recent literature in organizational economics (Parmigiani, 2007; Menard, 2013), we classified uncertainty into three groups, which capture the essential dimensions of the concept. We follow such classification and respective definitions to compose our three measures of uncertainty. These are, in theoretical terms, defined as follows:

a. Market uncertainty: captures the situations in which agents are uncertain about the fluctuations of supply and demand (this, both in terms of price and of quantity) (Robertson \& Gatignon, 1998).

b. Technological uncertainty: captures uncertainties relative to technological volatility (rapidly evolving technologies, rendering the current ones obsolete) and to its variety (different technological possibilities, such that it is hard to determine at the outset the best one).

c. Performance assessment uncertainty: captures the situations in which agents are uncertain about the adherence of the transacting parties to the contractual arrangements that had been established. This is more likely when there are difficulties 
in observing and measuring the performance of these parties: the harder it is to measure performance, the higher the risk of opportunism among parties (Barzel, 1982) and therefore, the higher the performance assessment uncertainty.

\subsubsection{Types of plural forms}

As mentioned before, plural forms are heterogeneous and may be found in a wide variety of manifestations. For instance, firms may combine vertical integration with acquisitions on the spot market (the well-known 'make-and-buy'), or they may contract for the procurement of a given input while producing some of it ('make-and-ally'); among other possibilities.

However, in order to keep our argumentation tractable, we group all the potential plural form manifestations into three subsets:

a. Between pure forms: captures the situations in which firms procure a given input by combining different classes of organizational arrangements (spot market, hybrids and hierarchy). The "mainstream make-and-buy", where firms acquire a given input on the spot market but also produce it in-house, is an example of this type of plural forms (we will refer to this typology as the 'between' type of plural forms).

b. Within hybrid forms: captures the situations in which firms procure a given input by combining different modalities that are typical of hybrid arrangements (ally-and-ally). To exemplify this situation, take a firm acquiring a given input, simultaneously, through relational contracts and through long-term formal contracts (we will refer to this typology as the 'within' type of plural forms).

c. 'Combo' forms: captures the situation in which firms combine (a) and (b) (make-allyand-ally, buy-ally-and-ally, or make-ally-ally-and-buy). This would be the case, for example, of a firm that, at the same time, acquires a given input on the spot market, and also contracts for part of this procurement by means of relational and of long-term contracts, or even, in some extreme cases, produces some of this given input in-house (we will refer to this typology as the 'combo' type of plural forms). 


\subsubsection{The relationship between multiple types of uncertainty and different typologies of plural forms: understanding the variety}

We have stressed in the preceding sections that the combination of asset specificity with uncertainty plays an important role in predicting plural or non-plural forms and we showed that there is a lot of heterogeneity in the composition of plural forms (Bob's burgers franchising vs. Minerva vs. Sao Manoel). In this subsection, we intend to explore and understand such heterogeneity by establishing relationships between the multiple types of uncertainty we defined before (market, technological and performance assessment) and the three categories of plural forms we created to keep our argumentation tractable ('between', 'within' and 'combo'), conditional to an intermediate degree of asset specificity (or close to it, being either slightly low or slightly high, but neither zero nor dedicated).

This idea has been more extensively explored in our chapter 3, and is based on a number of well-known empirical studies on the leading approach in TCE (markets vs. hierarchies vs. hybrids, rather than explicitly plural forms, although that is a finding that remained unexplored in many of these papers) - see Mahoney (1992). What all these contributions have in common is the finding that firms used different organizational arrangements, depending on how uncertainty was defined and treated in each one of them ${ }^{42}$.

If uncertainty plays a similar role in determining organizational arrangements in plural forms and in pure forms, than we should expect to find different types of plural forms, depending on the type of uncertainty affecting the transaction (or family of similar/identical transactions) at stake. Hence, in chapter 3, we propose the following hypothesis:

$H_{1}$ : There is a correlation between the type of uncertainty that affects a transaction (or a family of similar transactions) and the type of plural form adopted to deal with this transaction.

Following the rationale in $\mathrm{H}_{1}$, it is only logical to proceed with a discussion on these correlations, i.e., on the relationships between each type of uncertainty affecting a given

\footnotetext{
${ }^{42}$ We do not intend to discuss the controversial results of these empirical papers, but rather, present their findings to make our point. In fact, most of these papers have failed to analyze asset specificity along with uncertainty, therefore presenting ambiguous results (see already Shelanski \& Klein, 1995).
} 
transaction (or set of transactions) and the expected type of plural form, assuming specific assets to be at an intermediate level (or close to it, but never zero or dedicated). We extensively discuss and hypothesize on these correlations in chapter 3, and summarize this discussion here, as shown in Table 15.

Table 20. Hypotheses

\begin{tabular}{|c|c|c|c|}
\hline Hypotheses & $\begin{array}{c}\text { Type of } \\
\text { uncertainty }\end{array}$ & $\begin{array}{l}\text { Expected type of } \\
\text { plural form }\end{array}$ & Why? \\
\hline $\mathrm{H}_{1 \mathrm{a}}$ & Market & Between & $\begin{array}{l}\text { Gain flexibility and } \\
\text { secure specific } \\
\text { investments }\end{array}$ \\
\hline $\mathrm{H}_{1 \mathrm{~b}}$ & Technological & Between & $\begin{array}{l}\text { Gain/disseminate } \\
\text { information and } \\
\text { capabilities }\end{array}$ \\
\hline $\mathrm{H}_{1 \mathrm{c}}, \mathrm{H}_{1 \mathrm{~d}}$ & $\begin{array}{l}\text { Performance } \\
\text { assessment }\end{array}$ & $\begin{array}{l}\text { Between or } \\
\text { within, depending } \\
\text { of the level of } \\
\text { asset specificity }\end{array}$ & $\begin{array}{l}\text { Monitor and control } \\
\text { transacting parties and } \\
\text { secure specific } \\
\text { investments when these } \\
\text { are significant }\end{array}$ \\
\hline $\mathrm{H}_{1 \mathrm{e}}{ }^{a}$ & $\begin{array}{c}\text { Market and } \\
\text { technological or } \\
\text { Performance } \\
\text { assessment with } \\
\text { market or with } \\
\text { technological }\end{array}$ & $\begin{array}{l}\text { Between or } \\
\text { combo, } \\
\text { depending on } \\
\text { what is being } \\
\text { combined }\end{array}$ & $\begin{array}{l}\text { Linear combinations of } \\
\text { the plural forms used to } \\
\text { deal with each type of } \\
\text { uncertainty in isolation }\end{array}$ \\
\hline
\end{tabular}

Note: These relationships are developed with details in on our chapter 3.

${ }^{a}$ This hypothesis summarizes $\mathrm{H}_{1 \mathrm{e}}, \mathrm{H}_{1 \mathrm{f},} \mathrm{H}_{1 \mathrm{~g}}, \mathrm{H}_{1 \mathrm{~h}}, \mathrm{H}_{1 \mathrm{i}}$ in chapter 3 .

The basic notion underlying these correlations is that the organizational arrangements composing the plural form are complementary (Bradach, 1997), such that their combination allows firms to combine the strengths and neutralize the weaknesses of each arrangement alone. Take for instance the case of market uncertainty alone (the first line in Table 15). We argue that in this case, firms would choose to combine different classes of arrangements (market and hierarchy; market and hybrids; hybrids and hierarchy; or market, hybrids and hierarchy) - the 'between' type of plural forms - because by doing so they gain the flexibility required to deal with market uncertainty by using a less complex arrangement, while securing specific investments with a more complex arrangement. This is why we hypothesize in chapter 3 that:

$H_{\text {la: }}$ High market volatility (on the demand side or on the supply of inputs) pushes towards the adoption of the 'between' type of plural forms. 
Similarly, in the case of technological uncertainty, firms turn to the 'between' type of plural forms to absorb or disseminate information about the best technological choice or to gain/disseminate capabilities on how to operate it (for further details, see chapter 3). The underlying assumption here is similar to that in the Resource Based View of the firm (RBV), whereby firms are heterogeneous in terms of resources and capabilities. Therefore, by combining different classes of arrangements, firms can batter allocate these resources and capabilities, when they are uncertain about the best technological choice. This is why we hypothesize in chapter 3 that:

$H_{l b}$ : Technological uncertainty pushes towards the adoption of the 'between' type of plural forms.

Finally, the expected type of plural form associated with performance assessment uncertainty is due to the now classical notion of complementarities in franchising (Bradach, 1997). When specific assets are high (for example the brand name in the franchising case), firms must turn to the 'between' type of plural forms to prevent both company managers and transacting parties from acting opportunistically - they can better monitor and control both sides by benchmarking performance, while protecting these specific investments. But the same logic holds for when specific investments are rather low: because external parties have highpowered incentives, they tend to be more efficient than company employees. Yet, because performance assessment uncertainty is high, it hard to determine precisely the performance of these external parties. Therefore, firms must turn to the 'between' type of plural forms to benchmark performance and monitor and control both internal and external parties. This is why we hypothesize in chapter 3 that:

$H_{1 c}:$ Performance assessment uncertainty, when combined with low or high asset specificity, pushes towards the adoption of the 'between' type of plural forms.

Differently but still within the complementarities rationale, when asset specificity is at an intermediate level and performance assessment uncertainty is high, firms turn to the 'within' type of plural forms (or to a combination of hybrid arrangements) because hybrid arrangements best economize on transaction costs at this level of asset specificity. However, because of high performance assessment uncertainty, they must devise mechanisms to 
neutralize the possibility of opportunism and therefore enforce each type of hybrid arrangement with other. This is why we hypothesize in chapter 3 that:

$H_{1 d}$ : Performance assessment uncertainty, when combined with intermediate level of asset specificity, pushes towards the adoption of the 'within' type of plural forms.

We also admit that the 'real world' is complex and that, therefore, more than one type of uncertainty might affect a given transaction (or set of transactions) at the same time. This is why we also discuss the relationship between the combination of more than one type of uncertainty and the expected type of plural form. Our logic here is very simple: to deal with multiple types of uncertainty, firms will turn to a linear combination of the plural forms that would have been used to deal with each type of uncertainty alone.

For example, assume that a given firm uses both the spot market and long-term formal contracts to deal with high market uncertainty; and that the same firm uses relational contracts and hierarchy to deal with technological uncertainty. In this example, this given firm would use the spot market, relational contracts, long-term formal contracts and hierarchy (i.e., a 'combo') to deal with both high market and high technological uncertainty.

Of course, the expected type of plural form will depend upon the types of uncertainty affecting the transaction, and most importantly, on each particular plural form that is used to deal with each type of uncertainty alone, by the same given firm. In the example mentioned above, the resulting plural form was a 'combo' because of that firm combined two different 'between' types of plural forms (market and long-term contracts and relational contracts and hierarchy), each of which containing a different type of hybrid arrangement (long-term formal contracts and relational contracts, in this case). However, if the same firm turned to the spot market and to relational contracts to deal with market uncertainty and to relational contracts and hierarchy to deal with technological uncertainty, then, when resulting combination would be a 'between' type of plural form (spot market, relational contracts and hierarchy). Therefore, we summarize $\mathrm{H}_{1 \mathrm{e}}, \mathrm{H}_{1 \mathrm{f}}, \mathrm{H}_{1 \mathrm{~g}}, \mathrm{H}_{1 \mathrm{~h}}, \mathrm{H}_{1 \mathrm{i}}$ in chapter 3 into the following hypothesis:

$H_{l e}$ : Two types of uncertainty simultaneously affecting a given transaction push towards the adoption of the 'between' or the 'combo' types of plural forms. 
We should also mention that by definition, the 'within' type of plural forms should never be observed when more than one type of uncertainty affects a given transaction (or set of transactions). This can be justified by the fact that, when combining two types of uncertainties, it would only be possible to observe the 'within' type of plural forms when 'within' types of plural forms are used to deal with each type of uncertainty affecting this transaction ('within' = 'within' + 'within', but never 'within' = 'within' + 'between' for instance, by definition). But, if only performance assessment uncertainty alone pushes towards the 'within' type of plural forms, that scenario becomes impossible.

\subsection{Method and data}

We survey the procurement of the main inputs ( $\mathrm{T}^{*}$ in Figure 2 ) by 24 companies operating in the Brazilian Agribusiness sector. This selection was made by Menard et al (2014), taking care to guarantee a diversity of firms in terms of the inputs that are procured (11 different inputs: organic lettuce, meat, milk, 'cachaça ${ }^{43}$, coffee, cocoa, rubber, leather, grapes, sugarcane and cellulose pulp) and in terms of the way by which they are procured.

Figure 16. The transaction at stake: procurement of the main input.

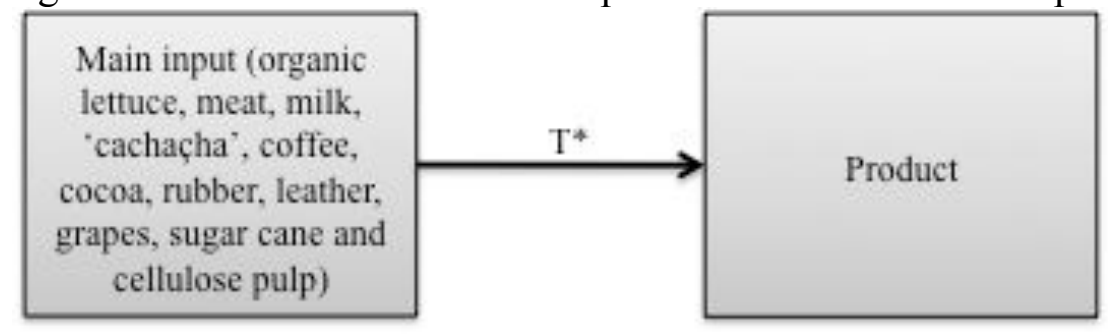

In that respect, an effort was made to select at least two companies procuring each input, so that at least one would do so by means of plural forms and one would choose to carry it out with non-plural forms. However, for some inputs (organic lettuce, sugar-cane, and milk), we were unable to find companies that would carry their procurement with non-plural forms, and therefore, only those using plural forms were selected.

\footnotetext{
${ }^{43}$ Brazilian type of rum made from sugar-cane.
} 
Moreover, special care was taken to fix the level of specific assets in $\mathrm{T}^{*}$, for each of the selected inputs. This is why, to compose the groups of companies procuring each input, special care was taken to guarantee that these were procuring very similar inputs ${ }^{44}$.

To construct our survey, we make use of a 4-point Likert-scale questionnaire (see the appendix), which was built and applied by Menard et al (2014) to measure 'ambiguity', 'complexity', 'strategic behavior' and 'asset specificity'; but was not exploited in their book, since they relied solely on the semi-structured interviews that were carried out in the same 24 companies $^{45}$.

Although we do not make use of all the questions in Menard et al. survey (2014), some of these questions can be used as proxies for the three types of uncertainties identified above, even though they do not completely capture them (see Error! Reference source not found., expressing our selection of questions, variables and proxies). For instance, questions assessing the predictabilities of supply and demand (1) can be used as proxies for market uncertainty, as it specifically captures those situations where agents are uncertain about the fluctuations of supply and demand.

\footnotetext{
44 This is not as relevant here as it was in Menard (2014) because in our case, we do not make an effort to compare the decisions of the pairs (or triplets) of companies procuring each input (requiring therefore that this variable remains as much as possible the same), but treat them independently, associating each type of uncertainty to the observed organizational arrangement.

${ }^{45}$ The questionnaire was not used in Menard et al (2014) because the case studies in plural forms focused only on the main motivation for this choice, while the questionnaire provides a more comprehensive and joint overview of many motivations.
} 
Table 21. Questions, variables and proxies

\begin{tabular}{ccc}
\hline Question & Variable & Proxy for \\
\hline $\begin{array}{c}\text { The demand for my inputs is highly } \\
\text { unpredictable }\end{array}$ & Demand volatility & Market \\
$\begin{array}{c}\text { The supply of my inputs varies a lot } \\
\text { during the harvest-year (climatic } \\
\text { issues, single harvest, no stocks, } \\
\text { etc.) }\end{array}$ & Supply volatility & \\
& & \\
\end{tabular}

It is hard to measure the quality of my inputs

Measurement cost

It is hard to determine the quantity

of inputs that is produced by my suppliers

Measurement cost

Measurement cost

Performance assessment

My inputs are certified so I don't have issues in measuring the quality offered by my suppliers (reversed: the higher uncertainty the value, the lower the measurement cost)

The quality of my inputs varies Measurement significantly cost/control

There are many different ways of producing my inputs

It is hard to determine the best technology to produce my inputs
Technological variety

Technological uncertainty

Technological variety/volatility

In order to control for the quality of my inputs I must rely in specialized personnel

The quality of my inputs is affected by time constraints

My suppliers can commercialize their production in various ways because they have many buyers

Quality is my main concern relative to my inputs
Human asset specificity

\section{Temporal asset specificity}

Quasi-rents (reversed: the higher the value, the lower the quasi-rent)

General asset specificity
Asset specificity 
(2) There are also questions that evaluate performance assessment uncertainty in the procurement of inputs by each firm. Since these are agricultural goods, this type of uncertainty was measured by de difficulty in evaluating quality and quantity of the inputs that are produced by outside suppliers, as well as by the perceived variations in terms of quality see Table 16.

Of course, these questions do not completely capture all dimensions of performance assessment uncertainty. For example, there are no questions directly assessing the possibility of measuring the supplier's productivity, nor are there any questions related to the internal measurement issues that could originate if the transaction were integrated. Despite this limitation, these questions could indeed provide us with some useful and interesting insights, especially when considering that, to our knowledge, this is the first paper that empirically relates different types of uncertainties (in association with asset specificity) with a variety of plural form manifestations.

(3) Finally, to capture technological uncertainty, we choose those questions assessing the perceived technological variety and volatility (see Table 16). These variables are good proxies for technological uncertainty because they capture essential dimensions of the concept, but are perhaps not enough to capture the entire concept. For example, there are neither questions measuring the possibility of technological change. But, once again, we stress that the available measures are enough to provide us with some initial insights on the relationship between multiples types of uncertainties and different typologies of plural forms.

Also, it worth mentioning that Menard et al (2014) took special care to select those measures of asset specificity that would be more relevant in the Agribusiness sector. Therefore, we keep all the questions measuring human, temporal and general asset specificity, as well as the perceived level of quasi-rents (we will get a reverse measure of the quasi rent: the higher the value, the lower the quasi-rent and vice-versa. This is because we asked firms if their suppliers had many buyers and therefore, the more buyers, the lower the quasi rent and viceversa)- see Table 16.

When it comes to the implementation of our model and the test of our hypotheses, what follows will remain exploratory and largely based on a qualitative analysis. Our procedure 
involved multiple steps and different levels of analyzes. We begin by establishing some descriptive statistics to get an overview of the responses for all the questions listed above (see Table 16). Next, we perform two groupings, both with respect to out variables and to the companies composing the sample, according to way by which they procure their inputs.

First, we group our questions into the four constructs we intend to capture: market uncertainty, technological uncertainty, performance assessment uncertainty and asset specificity (see Table 16) and valuate them. To this end, we compute the average scores and the standard deviations for all the questions belonging to each of these groups. We take care to estimate the internal consistency of the questionnaire by computing the Cronbach's alpha for each group. We do the same for the scores of each firm (to compose a measure of each type of uncertainty and asset specificity for each firm) and compute the overall level of uncertainty affecting each firm in our sample by adding together all the three scores mentioned before (minimum 0 , maximum 12). We choose to proceed that way for simplicity and, since we are not going to perform any econometrics, we are neither concerned with potential correlations between these variables nor with potential differences in terms of their relative weights in each firm. What we want to capture is each firm's perception of the overall level of uncertainty, assuming for simplicity that all types of uncertainty are equally important.

Next, we group the companies in our sample according to the way by which their inputs are procured: plural forms (3 categories: between, within and combo) vs. non-plural forms (a single category). By doing so, we are aware that we put aside the heterogeneity that also characterizes non-plural forms (spot market, standard hybrid arrangements, and hierarchy). But this is consistent with our objectives, since we are interested in determining the motivations to the existence and choice of various types of plural forms as an alternative to the use of non-plural forms, whatever their type.

Finally, we construct a table to connect each dimension of uncertainty and of asset specificity for each of the groups of companies described above. In that respect, once again, we rely on descriptive statistics, so that our investigation remains exploratory. Indeed, our sample is not suitable for more sophisticated statistical analyzes, especially considering its size and the limited number of questions on which we rely. 
For interpretation purposes, we consider a score of 1 as minimum (completely disagree) and a score of 4 as maximum (completely agree). Since there is no neutral point in a 4 point scale, we consider the average value between 1 and 4 (which is 2.5) as the intermediate value.

\subsection{Main findings and discussion}

We obtain 23 valid responses to the questionnaire, representing companies procuring 11 different inputs in the Brazilian Agribusiness sector and organize the presentation of our findings as follows: first, we present an overview of the responses considering the entire sample. Next, we classify the respondents into three groups, according to way by which they procure their inputs and present the main findings relative to these groupings.

\subsubsection{An overview of our entire sample}

In order to get an overview of our findings, we compute the average and the standard deviation for each question, considering our entire sample, as shown in Error! Reference source not found.. 
Table 22. Some descriptive statistics

\begin{tabular}{|c|c|c|c|c|}
\hline Variable & Question & Average & $\begin{array}{l}\text { Standard } \\
\text { deviation }\end{array}$ & $\begin{array}{l}\text { Cronbach's } \\
\text { alpha }\end{array}$ \\
\hline \multirow[b]{2}{*}{$\begin{array}{c}\text { Market } \\
\text { uncertainty }\end{array}$} & $\begin{array}{l}\text { The demand for my inputs is } \\
\text { highly unpredictable }\end{array}$ & 1.88 & 0.85 & \multirow[b]{2}{*}{0.56} \\
\hline & $\begin{array}{l}\text { The supply of my inputs varies } \\
\text { a lot during the harvest-year } \\
\text { (climatic issues, single harvest, } \\
\text { no stocks, etc) }\end{array}$ & 2.75 & 0.94 & \\
\hline \multirow{4}{*}{$\begin{array}{l}\text { Performance } \\
\text { assessment } \\
\text { uncertainty }\end{array}$} & $\begin{array}{l}\text { It is hard to measure the } \\
\text { quality of my inputs }\end{array}$ & 1.50 & 0.78 & \multirow{4}{*}{0.46} \\
\hline & $\begin{array}{l}\text { It is hard to determine the } \\
\text { quantity of inputs that is } \\
\text { produced by my suppliers }\end{array}$ & 1.96 & 1.04 & \\
\hline & $\begin{array}{l}\text { My inputs are certified so I } \\
\text { don't have issues in measuring } \\
\text { the quality offered by my } \\
\text { suppliers }\end{array}$ & 2.29 & 1.20 & \\
\hline & $\begin{array}{l}\text { The quality of my inputs varies } \\
\text { significantly }\end{array}$ & 2.88 & 1.08 & \\
\hline \multirow{2}{*}{$\begin{array}{l}\text { Technological } \\
\text { uncertainty }\end{array}$} & $\begin{array}{l}\text { There are many different ways } \\
\text { of producing my inputs }\end{array}$ & 2.83 & 1.09 & \multirow[b]{2}{*}{0.22} \\
\hline & $\begin{array}{l}\text { It is hard to determine the best } \\
\text { technology to produce my } \\
\text { inputs }\end{array}$ & 1.96 & 0.86 & \\
\hline \multirow{4}{*}{$\begin{array}{c}\text { Asset } \\
\text { Specificity }\end{array}$} & $\begin{array}{l}\text { In order to control for the } \\
\text { quality of my inputs I must } \\
\text { rely in specialized personnel }\end{array}$ & 3.29 & 0.81 & \multirow{4}{*}{0.54} \\
\hline & $\begin{array}{l}\text { The quality of my inputs is } \\
\text { affected by time constraints }\end{array}$ & 3.00 & 1.10 & \\
\hline & $\begin{array}{l}\text { My suppliers can } \\
\text { commercialize their production } \\
\text { in various ways because they } \\
\text { have many buyers }\end{array}$ & 2.88 & 1.03 & \\
\hline & $\begin{array}{l}\text { Quality is my main concern } \\
\text { relative to my inputs }\end{array}$ & 3.33 & 0.87 & \\
\hline
\end{tabular}


First, notice that when considering all questions, the average scores were very close either to 2 or to 3. Since there is no middle value in the 4-point scale (we defined it at 2.5), we can argue that the range between 2 and 3 is very close to the intermediate value we defined. This means that average scores were in the intermediate range, but were either quite high or quite low. We also realize that the standard deviations were very close to 1 and sometimes even slightly higher than that value. This could indicate that although the averages converged to the levels mentioned before, there is quite some heterogeneity in the respondents of all questions. In practical terms, this reflects the fact that in our entire sample, there are companies that responded high scores, companies that responded intermediate scores and companies that responded low scores. This expresses quite some heterogeneity in the sample and will potentially allow us to see some differences once we perform our groupings.

In a more detailed perspective of each of the variables, it is interesting to see is that, on average, companies claiming to face market uncertainty are more often disturbed by supply than by demand volatility. This is expressed by the difference in terms of the average scores resulting from the responses for the two questions related to market uncertainty. Nonetheless, market uncertainty alone, in general, was not significantly high, as the average values were either close to low or to intermediate values. However, because the standard deviation was close to 1 (quite high when considering a 4 point scale), there is significant dispersion in the responses for this variable, when considering our entire sample. Once again, this indicates that because market uncertainty was very high for some companies, but intermediate for others or even low; we might be able to see some differences in terms of the level of uncertainty once we perform our groupings.

When it comes to performance assessment uncertainty, the average score for the variation in terms of the quality of the procured input stands out. It presents the highest average level among all the questions measuring this dimension of uncertainty. However, because the standard deviation is considerable, we can infer that there is significant dispersion in the companies' perceptions of this type of uncertainty. Once again, this indicates that our sample is heterogeneous in terms of performance assessment uncertainty and that this could bring interesting insights once we perform our groupings. Besides results for the variation in the quality of the input, on average, there are either low or intermediate levels for all questions assessing performance assessment uncertainty. 
Finally, we can infer from the average scores that technological uncertainty (average 2.40) is, on average, slightly higher than performance assessment uncertainty (average 2.16). This is potentially more due to the various ways by which the input can be produced than to the inability to determine the best technology at the outset. But, because the difference in terms of the average scores for these questions is not very high and because there is a significant standard deviation in terms of the scores, we cannot jump to conclusions in that respect.

We found an intermediate to high level of asset specificity, considering our entire sample, since the average score on this variable was $2,92^{46}$. This is an important finding because in our model, the level of asset specificity is fixed at an intermediate level, or close to it from the left or from the right (indeed, it suffices that it is neither dedicated nor zero, as expressed in Figure 15). Therefore, we consider our findings to be, on average, close to $\mathrm{k}_{2}$ from the right, and hence, on average, our findings are at the 'intermediate' level in our model. This will allow us to focus on the different levels of uncertainty as motivators for distinct plural form manifestations (as shown in the hypotheses presented before).

Moreover, because of the considerable standard deviation in terms of asset specificity, we can infer that our sample also includes companies perceiving these investments as very high or as very low. Therefore, we will also be able to verify if these 'polar' scores tend to be associated with non-plural forms, as predicted in our model.

To verify the internal consistency of our groupings of questions (market, technological and performance assessment uncertainty and asset specificity), we rely on the Cronbach's alpha for each group and although these measures were barely acceptable, we choose to maintain our groupings to keep our analysis more tractable.

We suspect that these barely acceptable values were due to the way by which the groups have been defined. For instance, take the case of market uncertainty. Some firms could face high supply volatility, while other would be affected by high demand volatility. There also cases in which firms are affected by a combination of high supply and high demand volatility. Therefore, establishing a pattern in terms of the inter-item correlations becomes harder: these variables are sometimes negatively correlated and sometimes positively correlated. And as

\footnotetext{
${ }^{46}$ We computed the average after having reversed the scale for the question measuring the level of quasi rents: "My suppliers can commercialize their production in various ways because they have many buyers".
} 
Duhacheck and Coughlan (2005) argue, these inter-item correlations do affect the value of Cronbach's alpha.

We are aware of this and choose to eschew internal consistency in favor of combining the different questions to compose our 4 constructs (market, technological and performance assessment uncertainties and asset specificity). These questions capture different dimensions within these 4 constructs and provide a more comprehensive view of them.

Therefore, considering the argumentation above, we choose to keep our groupings, despite the low internal consistency.

To conclude this discussion, we summarize our main findings in terms of the average values for our entire sample. First, and in a more general perspective, we find that although our sample is small, our respondents seem to be quite heterogeneous and diversified; just as expected in a 'real world population of firms'.

Also, we find that on average, most of the variables were close to an intermediate level, although the high standard deviation indicated that there were also companies responding high and low scores for every question. This will potentially allow us to see some important differences once we perform our groupings in the next section. However, in preliminary terms, this finding indicates that on average, the level of uncertainty might not have been as high as expected and that the level of asset specificity is on average within our desired threshold (allowing us to focus on the different types of uncertainty as motivators for different types of plural forms).

\subsubsection{Groupings according to way by each firm procures its inputs}

Turning to more specific analyzes of the way through which the inputs are procured, we found three groups: plural forms of the 'between' and of the 'combo' types and non-plural forms - see Error! Reference source not found.. However, we found no cases for which the 'within' type of plural forms was used. And this is consistent with our hypothesis, predicting this arrangement only when there are intermediate levels of asset specificity and performance 
assessment uncertainty alone. Since there were no cases satisfying both conditions, we could not observe the 'within' type of plural forms, as expected.

Table 23. Summary of results

\begin{tabular}{|c|c|c|c|c|c|c|c|}
\hline \multirow[b]{2}{*}{ Company } & \multicolumn{5}{|c|}{ Uncertainty } & \multirow[b]{2}{*}{$\begin{array}{c}\text { Asset } \\
\text { Specificity }\end{array}$} & \multirow[b]{2}{*}{ Governance } \\
\hline & Market & Performance & Technological & Overall & $\begin{array}{l}\text { Average } \\
\text { by group } \\
\text { excluding } \\
\text { outliers }\end{array}$ & & \\
\hline Adecoagro & 3.50 & 2.00 & 3.00 & 8.50 & \multirow{9}{*}{7.39} & 3.75 & \multirow{9}{*}{$\begin{array}{l}\text { Plural } \\
\text { forms } \\
\text { between }\end{array}$} \\
\hline Miolo & 3.50 & 1.75 & 2.00 & 7.25 & & 3.75 & \\
\hline $\begin{array}{l}\text { Imbaúba } \\
\text { Laticínios }\end{array}$ & 3.00 & 2.50 & 3.00 & 8.50 & & 3.00 & \\
\hline $\begin{array}{c}\text { Café } \\
\text { Itamaraty }\end{array}$ & 2.00 & 1.75 & 2.50 & 6.25 & & 2.75 & \\
\hline Café Atalaia & 1.00 & 3.25 & 2.50 & 6.75 & & 3.25 & \\
\hline $\begin{array}{l}\text { Calçados } \\
\text { Doctor Pé }\end{array}$ & 2.00 & 2.25 & 2.50 & 6.75 & & 3.00 & \\
\hline Vibor & 1.50 & 1.75 & 1.00 & 4.25 & & 2.25 & \\
\hline Korin & 3.00 & 2.25 & 2.50 & 7.75 & & 3.00 & \\
\hline Average & 2.44 & 2.19 & 2.38 & 7.00 & & 3.09 & \\
\hline Bertin Ltda. & 3.50 & 3.00 & 1.50 & 8.00 & \multirow{7}{*}{8.15} & 2.25 & \multirow{7}{*}{$\begin{array}{l}\text { Plural } \\
\text { forms } \\
\text { combo }\end{array}$} \\
\hline São Manoel & 2.50 & 2.25 & 3.00 & 7.75 & & 3.00 & \\
\hline Minerva & 2.50 & 3.25 & 3.00 & 8.75 & & 2.50 & \\
\hline Klabin & 2.00 & 2.25 & 1.00 & 5.25 & & 2.50 & \\
\hline Porto Alegre & 2.50 & 1.75 & 4.00 & 8.25 & & 3.25 & \\
\hline Cultivar & 2.50 & 2.50 & 3.00 & 8.00 & & 3.25 & \\
\hline Average & 2.58 & 2.50 & 2.58 & 7.67 & & 2.86 & \\
\hline Pirassununga & 1.50 & 3.75 & 2.50 & 7.75 & \multirow{10}{*}{6.28} & 4.00 & \multirow{10}{*}{$\begin{array}{l}\text { Non-plural } \\
\text { forms }\end{array}$} \\
\hline ViniBrasil & 1.00 & 1.25 & 3.00 & 5.25 & & 4.00 & \\
\hline $\begin{array}{c}\text { Don } \\
\text { Laurindo }\end{array}$ & 2.50 & 1.75 & 2.50 & 6.75 & & 3.25 & \\
\hline Astro Café & 2.00 & 2.25 & 3.00 & 7.25 & & 3.00 & \\
\hline Indeca & 2.00 & 2.75 & 2.50 & 7.25 & & 2.50 & \\
\hline $\begin{array}{l}\text { Carmen } \\
\text { Steffens }\end{array}$ & 3.00 & 2.50 & 2.00 & 7.50 & & 2.75 & \\
\hline Amazonas & 2.50 & 1.75 & 2.00 & 6.25 & & 2.75 & \\
\hline Orsa & 1.50 & 1.00 & 1.00 & 3.50 & & 1.25 & \\
\hline Angelelli & 1.50 & 2.50 & 2.50 & 6.50 & & 2.25 & \\
\hline Average & 1.94 & 2.17 & 2.33 & 6.44 & & 2.72 & \\
\hline
\end{tabular}

First, as mentioned before, the overall level of asset specificity, considering our entire sample was 2,92. Very similar levels were found, on average, for all three groups: plural forms 'between', plural forms 'within' and 'non-plural forms'. This indicates that the level of asset specificity is close to $\mathrm{k}_{2}$ from the right (in Figure 1) for all groups (the intermediate point we defined is 2.5). And this is consistent with our model: for intermediate levels of asset specificity (or close to it from the left of $k_{1}$ or from the right of $k_{2}$ in Figure 15), both plural 
and non-plural forms are expected, depending on the levels of uncertainty affecting the transaction.

Another interesting finding relative to asset specificity is that the standard deviation of this variable is much smaller in both plural form groups $(0.50$ and 0.43 for the 'between' and 'combo' groups) than in the non-plural form group (0.86). This indicates that the procurement of inputs by the companies placed in both plural form groups always involves intermediate levels of asset specificity (according to the criteria mentioned before), while those procuring their inputs through non-plural forms are subject to low, intermediate and high levels of asset specificity. In fact, all the companies placed in both plural form groups present a level of asset specificity between 2 and 3. In contrast, the non-plural form group is much more diverse, whereby 4 out of the 9 companies present either low or high levels of asset specificity (Pirassununga, ViniBrasil, Don Laurindo and Orsa). Once again, these findings are consistent with our model, because we only predict plural forms for intermediate levels of asset specify but predict non-plural forms for low, intermediate and high levels of asset specificity, depending on the degree to which uncertainty affects these transactions.

As far as the overall average level uncertainty is concerned, we found intermediate or slightly high levels for both plural form groups ${ }^{47}$ (7.39 and 8.15), but we found a slightly low value for the non-plural form group (6.28). This is consistent with our model, since we only predict plural forms when uncertainty is above $\mathrm{u}_{1}$ in Figure 15, i.e., when uncertainty is rather high. In turn, we predict non-plural forms when uncertainty is below $\mathrm{u}_{1}$, regardless of the level of asset specificity.

Nonetheless, we must mention that the threshold level of uncertainty $\mathrm{u}_{1}$ was not as high as expected. This suggests that intermediate levels of uncertainty suffice to switch the choice of non-plural forms to that of plural forms, and therefore, that $\mathrm{u}_{1}$ should be lowered. This does not invalidate our prediction because lowering $\mathrm{u}_{1}$ is a matter of changing the scale of the graph, but what is interesting and deserves attention is the interpretation of such adjustment: the non-negligible possibility of being affected by the hazards brought by uncertain conditions

\footnotetext{
${ }^{47}$ Considering that the scale for this variable ranges from 1 to 12 because we add together three 4-point scales, and that in each of these scales the neutral or intermediate point is 2.5 , the intermediate value for the overall average level of uncertainty is 7.5 .
} 
suffices to push firms into devising mechanisms to deal with these problem, such as turning to plural forms.

Once we jointly analyze our findings for both asset specificity and uncertainty, we find support for the 'U-shaped curve' shown in Figure 1: plural forms are associated with higher levels of uncertainty and with intermediate levels of asset specify (the grey zone in Figure 15). Furthermore, there are no cases of plural forms for very low or very high levels of asset specify (the 'polar cases' in our model). On the other hand, non-plural forms are associated either with (a) lower levels of uncertainty, regardless of asset specificity (below $u_{1}$ ) - see the cases of ViniBrasil, Orsa and Amazonas (b) very high or very low levels of asset specificity, regardless of uncertainty (the 'polar cases' in our model, close to zero or to dedicated assets) see the case of Pirassununga and Angelelli. All these findings provide support for the ' $U$ shaped' curve in Figure 1, although $\mathrm{u}_{1}$ is lower than predicted, as mentioned before.

As far as the relationship between multiple types of uncertainty and the different types of plural forms is concerned, the first thing that stands out is the fact that all three types of uncertainties affected all companies in our sample. To put it more sharply, we could not observe any cases where a unique type of uncertainty affected the procurement of inputs. This means that the 'real world' is complex and that each type of uncertainty taken in isolation is a stylized case designed to help us in understanding a more complex situation. Therefore, we could not confront our hypotheses relative to each individual type of uncertainty alone $\left(\mathrm{H}_{1 \mathrm{a}}\right.$, $\mathrm{H}_{1 \mathrm{~b}}$ and $\left.\mathrm{H}_{1 \mathrm{c}}\right)$.

Despite this fact, we found some indications that market uncertainty would push towards the 'between' type of plural forms (i.e., in favor of $\mathrm{H}_{1 \mathrm{a}}$ ) because this variable is what most distinguished the 'between' plural form group from the 'non-plural' form group. We found a difference of 0.5 in terms of the market uncertainty scores between the two groups and this is the largest difference in both groups when considering market, technological and performance assessment uncertainty ${ }^{48}$ and that both groups are subject to similar levels of asset specificity.

We were also unable to explicitly confront our hypotheses relative to the combinations of market and technological uncertainty or that of market or technological uncertainty with

\footnotetext{
${ }^{48}$ We found a 0.02 difference for performance assessment uncertainty and 0.05 for technological uncertainty.
} 
performance assessment uncertainty because we methodologically remained limited to these three combinations of pairs of uncertainties, and we were only able to find the combination of all three types of uncertainty. Nevertheless, our findings were consistent with our predictions for each pair $\left(\mathrm{H}_{1 \mathrm{~d}}\right)$ : both the 'between' type of plural forms' and the 'combo' were observed, but never the 'within' type. This provides insights in favor of our hypothesis $\mathrm{H}_{1 \mathrm{~d}}$, although this confrontation deserves further empirical studies.

Another aspect worth mentioning in that respect is that although we were indeed able to observe both the 'between' type of plural forms and the 'combo', we could not determine the underlying mechanisms that generated such combinations. To say it differently, although in theoretical terms we can isolate which plural form is used to deal with each type of uncertainty that simultaneously affects the transaction, in empirical terms this cannot be made: we can observe the resulting plural form combination, but we cannot isolate the parts associated with one or another type of uncertainty.

Relatedly and to conclude, a novel finding relative to our hypotheses is that the 'combo' type of plural forms group presented the highest level of uncertainty among all three groups. And not only is this relative to the overall level, but also to each individual level of uncertainty in isolation. This could indicate that more complex modes of organization are well-suited to deal with high levels of multiple types of uncertainties. An implication of this finding could be the inclusion of following additional hypothesis:

$H_{l e}:$ For intermediate levels of asset specificity, the combination of high market, high technological and high performance assessment uncertainties pushes towards the adoption of the 'combo' type of plural forms.

\subsubsection{Limitations}

Our findings were limited in some aspects and must be regarded as exploratory indications about theoretical model and hypotheses. First, as mentioned before, our analyses were based on the questionnaire developed and applied by Menard et al (2014), but that was only partially exploited in that book. Hence, although we did have enough data to measure all our variables 
of interest, these were incomplete measures, limited to the information available in that questionnaire.

Second, our database did not allow us to perform quantitative analyses because of its size and lack of control variables. Therefore, we remained limited to some descriptive statistics. We were also unable to determine the statistical significance of our findings, which limits the possibility generalizing our results. This becomes more of an issue because we did find some interesting results.

Perhaps the major limitation in our analyses was a measurement problem. Because the Likert scales were composed of only 4 points, we found very little dispersion in our data. We do not mean that the standard deviation was low or that the sample was not heterogeneous, but rather, that the difference in terms of the scores for each variable, in the multiple cases, was very small. As a result, all three groups (plural forms 'between' and 'combo' and 'non-plural forms') received very similar scores. But, if the scale had more points, 7 for instance, we would perhaps be able to observe more significant differences between these scores and draw more consistent conclusions. With our current data, we must only stress that we are aware of this limitation and that our results are indeed based on very small differences.

\subsection{Final remarks}

In this chapter, we introduced some empirical evidence to confront our theoretical model and hypotheses relative to the existence and to the variety of plural form manifestations. To our knowledge, we were the first to develop such evidence and to do so in relation to a model that we consider innovative.

Despite all the limitations in our study, we found evidence supporting the hypotheses derived from our theoretical model, to the effect that the combination of the levels of uncertainty and of asset specificity can predict the emergence of plural or non-plural forms. There is, therefore, empirical support for our model incorporating plural forms in the Transaction Cost Economics framework. 
In that respect, as expected we found that plural forms prevail when specific investments are neither zero nor dedicated, but fall within the intermediate range between these 'polar' cases, and when uncertainty is significant, exceeding a threshold that we have identified as $\mathrm{u}_{1}$ and that we explicated by discussing three types of uncertainty.

However, differently from our prediction, these organizational arrangements prevail even when the level of uncertainty is not as high as expected. Although reducing the threshold level for uncertainty does not invalidate the model, it could indicate that firms turn to these more complex organizational arrangements because they feel the need to avoid the hazards brought by some non-negligible uncertainty. Therefore, an intermediate level of uncertainty (or close to it) is enough to push decision-makers into devising mechanisms to deal with it, rather than the high expected levels.

This required level $\left(\mathrm{u}_{1}\right)$, that is lower than initially expected, may also indicate that in the presence of specific investments, even if this specificity is moderate, decision-makers still look for arrangements that can secure these investments. If it is so, this consequence would consolidate the importance given to the specificity of assets as a determining attribute of transactions in the Williamsonian approach. Although potential measurement errors could have contributed to artificially pushing this average value of uncertainty downward, the idea that the threshold level might not be as high as expected still holds and does not invalidate our model.

We could also find some indications supporting our hypotheses relative to the diversity of plural form manifestations. As predicted, we found that the combination of more than one type of uncertainty affecting a given transaction (or set of transactions) pushes towards the adoption of the 'between' or the 'combo' types of plural forms, but never to the 'within' type. In that perspective, however, two remarks deserve particular attention.

First, going beyond the combinations in terms of the pairs of uncertainty (market and technological, market and performance assessment, technological and performance assessment), we found that all three types of uncertainties affected the procurement transactions of all the companies in our sample. However, the idea that their combinations would never push towards the 'within' type of plural forms still held empirically. 
Nonetheless, because the 'combo' group presented the highest level for all three types of uncertainty when compared to the other two groups, we proposed the inclusion of a novel hypothesis capturing the three combinations and proposing that these three, together with intermediate levels of asset specificity, push towards the adoption of the 'combo' type of plural forms. But this hypothesis deserves further empirical studies.

Second and relatedly, we were able to observe the plural organizational arrangements that were used in order to deal with all three types of uncertainty. However, differently than what we had expected from our theoretical model, we were unable to verify the underlying mechanisms that led to this result. More explicitly, we could not observe which arrangements, within the 'between' or the 'combo' types of plural forms, were selected to deal with each type of uncertainty. This finding, together with the fact that all three types of uncertainties affected all transactions, indicates that the 'real world' is complex and that the hypotheses relative to each individual type of uncertainty constitute mere stylized formalizations to enable a better understanding of this complex situation. But after all, this is what models are about. And looking at the data collected, we found indications that market uncertainty would be the leading motivation for choosing the 'between' type of plural forms, that is, the combination of different classes of organizational arrangements; which is already an interesting result.

Notwithstanding the limitations already mentioned, which prevented our statistics to be conclusive, our empirical investigation provided interesting indications that support our model and several hypotheses we derived from that model. These are important findings, given that this was the first work to assess the existence of various plural forms, even though we are fully aware that our investigation still remains exploratory. Nevertheless, our supportive evidence certainly makes room for further analyses in that direction. 


\section{Chapter 6}

\section{Conclusion}

In this dissertation, I addressed a challenging topic in organizational economics: plural forms of organization. I showed, through the bibliometric survey developed in chapter 2 , how the field has evolved over time, especially focusing on the multiple theoretical explanations for the existence of plural forms. I concluded that the combination of asset specificity and multiple types of uncertainty underlies most of the explanations used over time. I also found that there are almost no papers addressing the heterogeneity of plural forms.

I used these results to make two novel theoretical contributions of my own: first, I built a theoretical model integrating asset specificity and uncertainty to predict when plural forms or non-plural forms should prevail. Second, I stressed that plural forms are heterogeneous and derive a number of hypotheses to clarify this variety (see chapter 3 ).

The empirical contributions in chapter 4 and 5 provided some interesting insights in favor of my model and hypotheses, as well as additional ideas that should be incorporated in my framework. First, I found evidence on both chapters 4 and 5 in favor of my "U" shaped curve associating asset specificity and uncertainty to predict plural forms. However, my findings in chapter 5 indicate that the threshold level of uncertainty $\left(\mathrm{u}_{1}\right)$ in my model is not as high as expected, but closer to an intermediate level. This does not invalidate my model, since adjusting $\mathrm{u}_{1}$ to the correct level is a matter of slightly modifying the scale (or moving the curve downwards). But an important implication of this finding is its interpretation: intermediate levels of uncertainty suffice to push towards more complex arrangements because companies wish to avoid the consequences brought by uncertain situations.

I also found support for the idea that transactions affected by different levels of asset specificity and uncertainty are distributed distinctly along my model, and therefore, should be 
organized with different arrangements (see Figure 14). These two findings, together, provide some strong empirical evidence in favor of my theoretical model. Nonetheless, I should mention that both chapters 4 and 5 remained essentially qualitative and limited in terms of the generalizability of my results and of the statistical significance of these findings. Therefore, additional empirical contributions, particularly of the quantitative type, become required in order to conclude with more confidence that the model holds empirically. However, given that my papers were the first to assess this model, their results gain additional relevance and indicate that the model should hold elsewhere.

I also found support for some of my hypotheses. Although only chapter 5 explicitly addressed them empirically, a careful examination of my findings in chapter 4 also provides some insights in their favor. For instance, the idea that the combination of more than one type of uncertainty pushes towards the 'between' type of plural forms or towards the 'combo' type (but never the 'within' type $-\mathrm{H}_{1 \mathrm{e}}, \mathrm{H}_{1 \mathrm{f}}, \mathrm{H}_{1 \mathrm{~g}}, \mathrm{H}_{1 \mathrm{~h}}, \mathrm{H}_{1 \mathrm{i}}$ ) was explicitly verified and confirmed in chapter 5 , but is also a finding in chapter 4 , since the cases of the eggs and organic corn are affected by market and performance assessment or by technological and performance assessment uncertainties (respectively) and are organized with the 'combo' type of plural forms.

Relatedly, I found that each individual type of uncertainty in isolation is more of a stylized representation to assist us in understanding a more complex reality than a model per se. In fact, except for the case of regular corn in chapter 4, which is only affected by market uncertainty, a unique type of uncertainty affected no other cases. Rather, at least two types of uncertainty were combined in all the remaining 18 cases of plural forms, and three types affected 16 of these cases.

As expected, the combination of two (or more) types of uncertainty pushed towards the 'between' or the 'combo' type of plural forms in both chapters 4 and 5. And because of the complex reality mentioned before, no evidence was found for $\mathrm{H}_{1 \mathrm{~b}}$ (technological uncertainty alone) and $\mathrm{H}_{1 \mathrm{c}}$ (performance assessment uncertainty alone). However, I could find some indication that market uncertainty pushes towards the 'between' type of plural $\left(\mathrm{H}_{1 \mathrm{a}}\right)$ forms in chapter 5 because it was this variable that best differentiated the plural form of the 'between' type group and the non-plural form group. However, in the case regular corn shown in chapter 
4, this type of uncertainty alone pushes towards the 'within' type of plural forms. Given this divergence, I cannot jump to conclusions: on the one hand, chapter 5 comprises a more comprehensive set of firms but on the other, chapter 4 presents the only case where a single type of uncertainty alone affected the procurement transaction. Error! Reference source not found. summarizes my conclusions relative to my hypotheses.

Table 24. Conclusions

\begin{tabular}{ccc}
\hline Hypotheses & Evidence & Chapter \\
\hline $\mathrm{H}_{1 \mathrm{a}}$ & Yes & 5 \\
$\mathrm{H}_{1 \mathrm{a}}$ & No & 4 \\
$\mathrm{H}_{1 \mathrm{~b}}$ & No & - \\
$\mathrm{H}_{1 \mathrm{c}}, \mathrm{H}_{1 \mathrm{~d}}$ & No & - \\
$\mathrm{H}_{1 \mathrm{e}}, \mathrm{H}_{1 \mathrm{f}}$ & Yes & 4 and 5 \\
$\mathrm{H}_{1 \mathrm{~g}}, \mathrm{H}_{1 \mathrm{~h}}, \mathrm{H}_{1 \mathrm{i}}$ & Yes & 4 and 5 \\
\hline
\end{tabular}

My results in chapter 5 also suggest that an additional hypothesis be made, considering the combination of all three types of uncertainty and intermediate levels of asset specificity: The combination of high market, high technological and high performance assessment uncertainties with an intermediate level of asset specificity pushes towards the 'combo' type of plural forms. This is supported by the finding that the 'combo' group of plural forms presented the highest levels of overall uncertainty and of each individual level of uncertainty in isolation, in chapter 5 . Add to this result the finding that the cases of the eggs and organic corn, in chapter 4 , were affected by the highest perceived levels of uncertainty and were organized with the 'combo' type of plural forms.

To conclude, I found support for my theoretical model and for some of my hypotheses, as summarized in Error! Reference source not found., below. Moreover, my empirical papers provided some feedback to my theoretical contribution, both in terms of the model and the hypotheses. 
Table 25. General conclusions

\begin{tabular}{cc}
\hline $\begin{array}{c}\text { Theoretical model } \\
\text { Hypotheses }\end{array}$ & $\begin{array}{c}\text { Supported } \\
\text { Partially supported }\end{array}$ \\
\hline Feedback \\
\hline Theoretical model & $\begin{array}{c}\text { Lower threshold } \mathrm{u}_{1} \\
\text { Add prediction to the } \\
\text { Hypotheses }\end{array}$ \\
& $\begin{array}{c}\text { combination of the three } \\
\text { types of uncertainty }\end{array}$ \\
\hline
\end{tabular}

As mentioned before, they suggested that I lower the threshold in my theoretical model and that I add a hypothesis predicting the 'combo' type of plural forms when three types of uncertainty are combined.

I found interesting results, given that my theoretical contributions are novel and that I could find some support for them. However, as expected, some new questions arose and others remained unanswered. I could not verify the effects of technological and performance assessment uncertainties in isolation, when combined with intermediate asset specificity. Neither could I tell which parts of the observed organizational arrangements were used to deal with each type of uncertainty, when more than one type affected a given transaction. To say it differently, when two or more types of uncertainty, together with intermediate asset specificity affected a given transaction (or set of transactions) and pushed towards the 'between' or the 'combo' type of plural forms, I was unable to tell which arrangements within those observed were used to deal with one or another type of uncertainty alone (differently than in my theoretical explanation for these hypotheses, whereby I predict the linear combination of the organizational arrangements used to deal with each type of uncertainty alone).

An emerging question related to the diversity of plural forms concerns the relative weights of each organizational arrangement composing the plural form: why is it that some companies combine $50 \%$ spot market and $50 \%$ hierarchy while others rely $10 \%$ on the spot market and $90 \%$ on hierarchy, although they are both using the 'between' type of plural forms and the same classes of organizational arrangements? 
Another emerging path for future research concerns a potential relationship between the relative weights of the organizational arrangements composing the plural form and the type of plural form at stake. For instance, could a more uniform distribution of these weights (e.g. $50 \% 50 \%, 33 \%, 33 \%, 33 \%$, etc.) be associated to a particular group of plural forms (e.g. 'between' or 'combo') while a non-uniform distribution (e.g. 90\% 10\%, 10\%, 10\%, 80\%, etc.) would be associated with another group of plural forms? If so, which associations are expected and why? 


\section{Appendices}

\section{Korin - Interview Guide}

1. Describe a brief history of your business and its focus.

2. What are the products produced by your firm (fine wines, table wines; Milk A, Milk B; specialty coffee traditional coffee, etc.)? Mention percentages.

3. Are there different ways to capture the raw material for each product to be produced? (e.g. fine wines, table wines; Milk A, Milk B; specialty coffee; traditional coffee, sugar, ethanol etc.)

4. Name some key raw materials:

5. How do you obtain these raw materials? (Mention percentages). Are there are different ways obtain the raw material(s) for different end products? (Use the Table below).

\begin{tabular}{|c|l|l|l|}
\hline Means of acquiring & RM1 & RM2 & $\ldots$ \\
\hline Own production (Vertical integration) & & & \\
\hline Outsourced production & & & \\
\hline Spot market & & & \\
\hline $\begin{array}{l}\text { Relational suppliers (no formal } \\
\text { contract) }\end{array}$ & & & \\
\hline \begin{tabular}{l} 
Suppliers with formal contract \\
\hline
\end{tabular}
\end{tabular}

Notes: If there is a contract, are price and volume defined?

6. Has the raw material always been obtained in this way? (Cite history, and if there were changes, why?)

7. Indicate the main reason for using this way of obtaining the raw material.

8. Do you provide any benefits to some suppliers? If so, which benefits and to which 
suppliers? (Example: seedlings, manure, fertilizer, technical assistance etc.)

9. Describe the production stages coordinated by the firm (seed delivery, harvest, transportation etc). What are the most critical steps?

10. How many suppliers (total)? How do you choose your suppliers? Why? (Proximity, raw material quality, raw material price, suppliers' technological level etc.). Are they always the same?

11. Are there many raw material suppliers? (Easy to obtain on the market). Does the supply vary throughout the year? (Weather problems, single crop in a limited period of time, and no possibility to stock). How to deal with price or demand fluctuations? Are these fluctuations seen as an opportunity or a risk?

12. How and by whom is the raw material quality measured? And why? (Certification, regulation, ways to measure quality-explain, give examples: local inspection, lab analysis etc.). Is it difficult to measure quality? How is the raw material supplier monitored?

13. Are breaches of contract frequent on the part of the suppliers (non-compliance with terms, prices, quality, and quantity). What are the procedures to solve disputes? Are they formally defined? Are there punishments? What are they?

14. Is the demand of raw material predictable (stable consumption)?

15. Are there different ways/processes/technologies to produce your raw material? (Mechanical cultivation and harvest, drying, different seeds-GMO, GMO-Free, varietals, irrigation, GPS, etc.). Is it difficult to assess which is the best?

16. Have there been technological changes over the last years? If so, were they imposed by the government? How have they been disseminated? (Briefly cite which) Are you and your suppliers equally prone to technological change and its dissemination? (Cite and comment).

17. Does the raw material quality vary significantly? Is it affected by time restrictions? (Perishability of the produce in the field, need to do the harvesting quickly, or scheduling of the industrial processing etc.)

18. Are specialized professionals necessary to assess the raw material quality? (Own personnel, an external firm or agency etc.).

19. Do your suppliers have other buyers for their raw material? Do raw material suppliers wield bargaining power?

20. Do you have special suppliers (who receive technological information or technical assistance which others do not)? Why?

22. Is it hard to measure the performance/productivity of your employees? (Describe and 
comment). Do you offer any special compensation? What about your suppliers? Can you tell their productivity?

\section{Questionnaire (free translation from Portuguese)}

Case:

We are grateful for your participation in this research and kindly ask you to fill out the following questions.

a. Main input:

b. For the following statements, indicate your level of agreement or disagreement considering the scale: 1 (strongly disagree), 2(disagree), 3(agree), 4 (strongly agree).

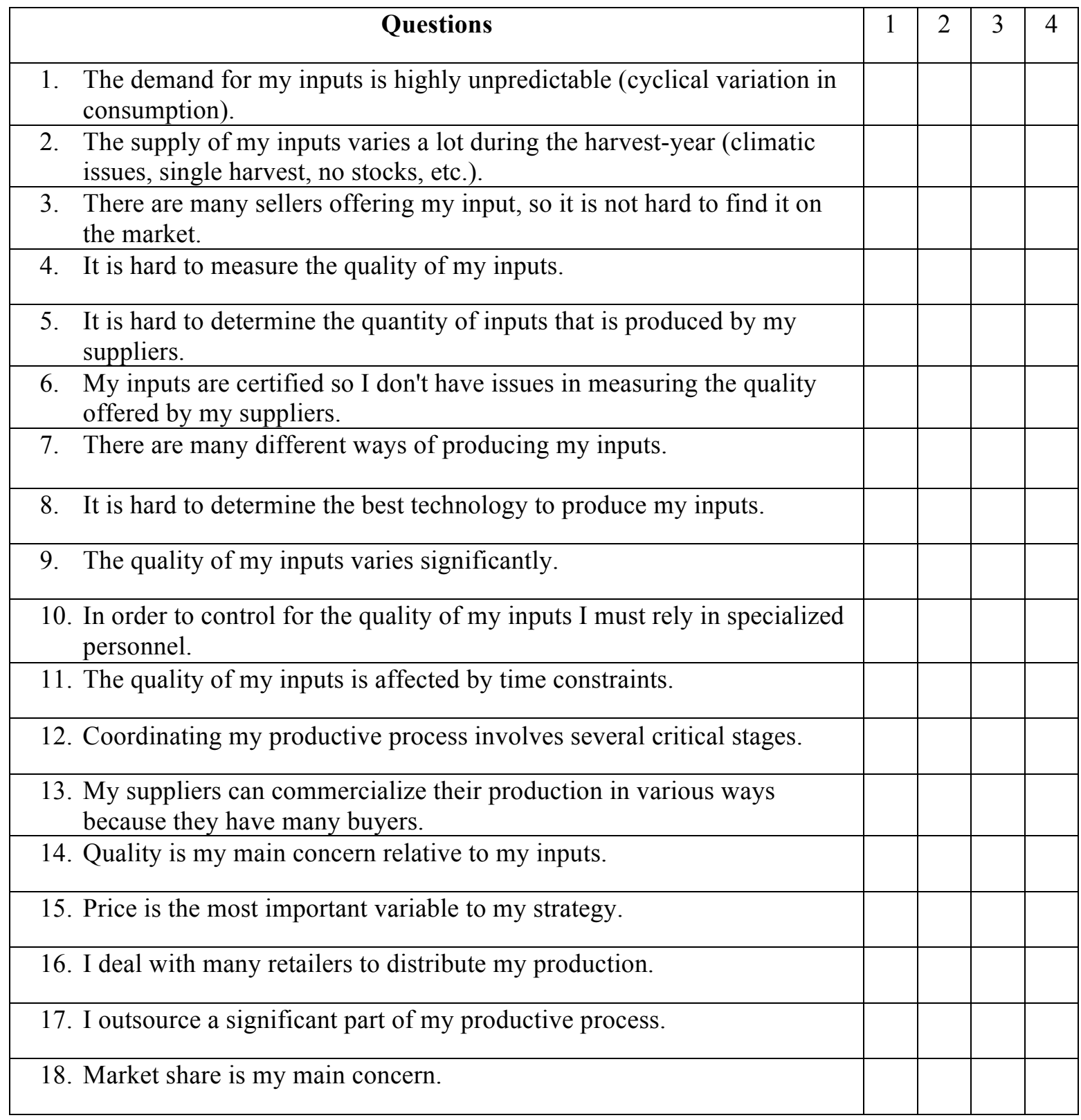



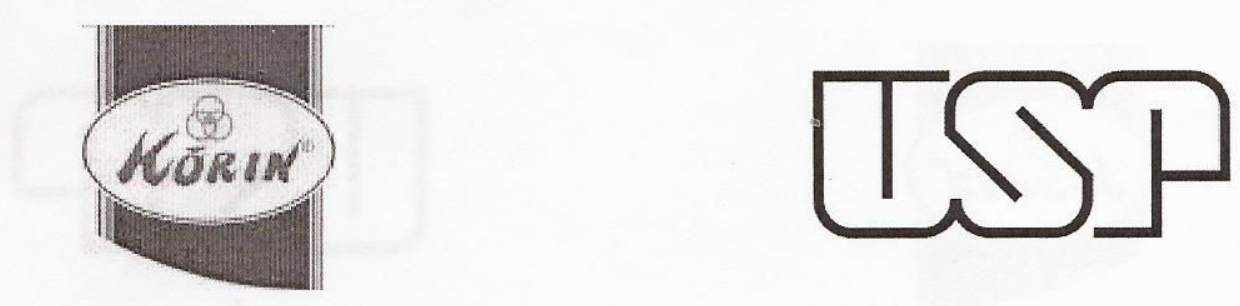

\section{TERMO DE COMPROMISSO E CONFIDENCIALIDADE}

Pelo presente instrumento e na melhor forma de direito, de um lado Luiz Carlos Demattê Filho, representando a Korin Agropecuária Ltda., inscrita no CNPJ sob o número 00.153.705/0003-00, por sua filial de Ipeúna-SP, lograda na Estrada Municipal de Camaquã, s/ nº, Município Ipeúna, Estado de São Paulo, aceita participar como voluntário no estudo em questão, de outro lado:

a) Estudante Paula Sarita Bigio Schnaider, doutoranda em Ciências Econômicas pela Université Paris 1 - Panthéon-Sorbonne e em Administração pela Universidade de São Paulo.

b) USP - Universidade de São Paulo, Faculdade de Economia Administração e Contabilidade. Rua Professor Luciano Gualberto, 908 FEA I - sala C16 Butantã 05508-900 - Sao Paulo, SP - Brasil, neste representado pela Professora Dra. Maria Sylvia Macchione Saes.

I - Os termos:

Manter sob sigilo toda e qualquer informação confidencial, que não tenha sido obtida de fontes usuais e de domínio público e que tenha sido obtida em razão das atividades desempenhadas na pesquisa exposta no projeto de pesquisa. Entende-se como informação confidencial, toda informação obtida relativa a área de atuação do(s) experimento(s) que tenha acesso, sob forma escrita, verbal, pela mídia eletrônica ou por outros meios audiovisuais.

Também não será permitido divulgar, publicar ou noticiar resultados, dados, técnicas gerais ou específicas ou qualquer outra informação oriunda do projeto de pesquisa de forma escrita, verbal ou audiovisual sem prévia e formal autorização da Korin Agropecuária Ltda.

A dissertação ou tese na sua versão integral, deverá ser submetida a Korin Agropecuária Ltda. para avaliação e autorização antes de que a mesma seja depositada, comunicada ou catalogada oficialmente em qualquer base de dados pública ou privada, a qual não implica em autorização automática para a publicação de resumos, notificações, comunicados ou artigos técnicos e científicos sobre os dados e resultados do projeto de pesquisa. Tais publicações serão tratadas oportunamente mediante acordos específicos.

Ipeúna, 19 de junho de 2015. 

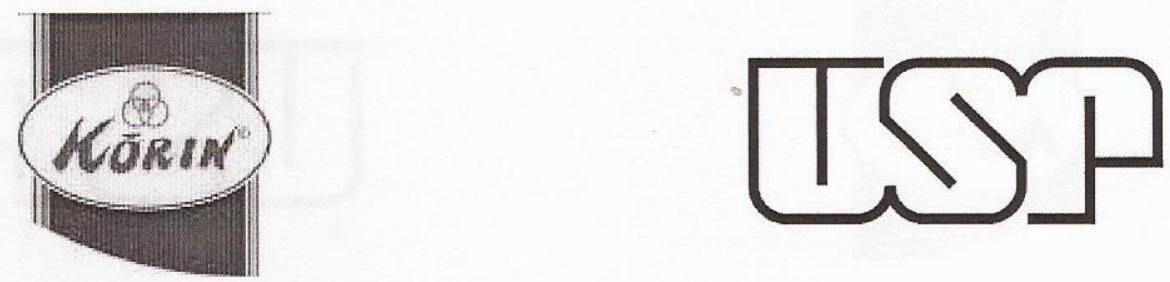

Prof. Dr. Maria Sylvia/Macchione Saes Universidade de São Paulo
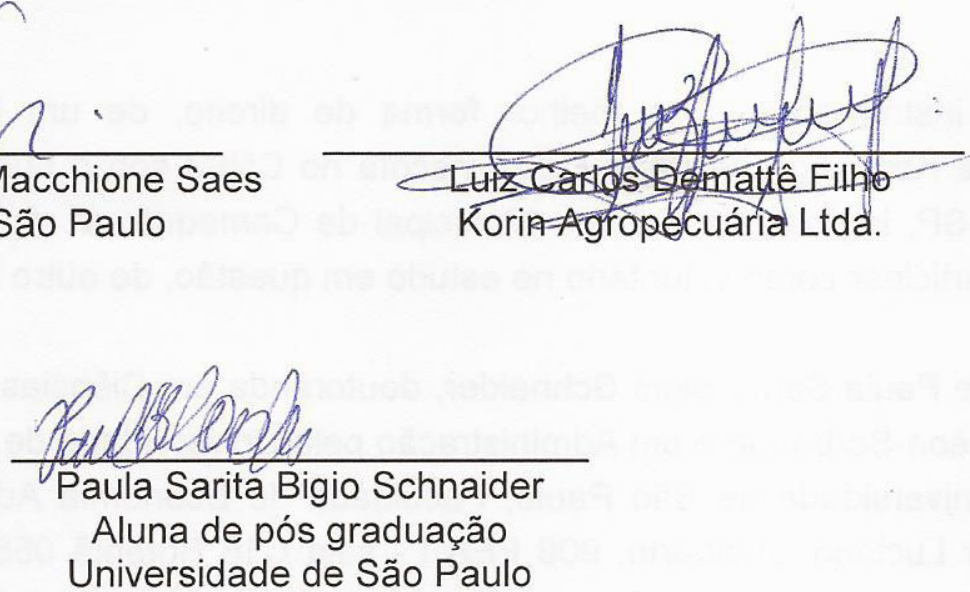


\section{DECLARAÇÃO}

Eu, LUIZ CARLOS DEMATTE FILHO, declaro que concordo em participar, como voluntário do estudo e autorizo o uso das informações relativa a KORIN AGROPECUÁRIA LTDA., por mim prestadas em entrevista realizada no dia 08 de junho de 2015, bem como a divulgação do nome da empresa, em trabalhos, assim como tese, artigos e livros, provenientes da tese da discente PAULA SARITA BIGIO SCHNAIDER, doutoranda em dupla titulação entre a FEA-USP e a Universidade de Paris 1 - Panthéon - Sorbonne. A pesquisa é realizada sob orientação da profa. MARIA SYLVIA MACCHIONE SAES, da Universidade de São Paulo, e do prof. CLAUDE MENARD, da Universidade de Paris 1 . Os responsáveis pela presente pesquisa assumem o compromisso de compartilhar o material produzido antes de sua publicação e de não divulgar informações que não estejam de acordo com a política de privacidade da empresa. Esta declaração vincula-se como parte inseparável do termo de compromisso e confidencialidade assinado entre as partes.

São Paulo, 08 de junho de 2015.

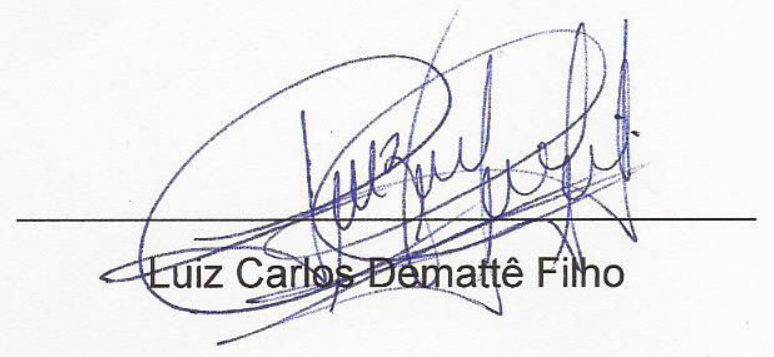




\section{DECLARATION}

I, LUIZ CARLOS DEMATTÊ FILHO, hereby declare that I agree to participate as a volunteer to this study and that I authorize the use of information relating to KORIN AGROPECUÁRIA LTD. that I provided in an interview held on June $8^{\text {th }}, 2015$, as well as the disclosure of the company name, in works such as doctoral dissertations, articles and books originating from the doctoral dissertation by PAULA SARITA BIGIO SCHNAIDER, a student in a dual degree between FEA-USP and the University of Paris 1 - Panthéon - Sorbonne. The above-mentioned research is conducted under the supervision of Prof. MARIA SYLVIA MACCHIONE SAES, from the University of São Paulo, and Prof. CLAUDE MENARD, from the University of Paris 1. Those responsible for this research are committed to share the produced material before its publication and not to disclose information that is not in accordance with the privacy policy of the afore-mentioned company. This declaration is linked to and is an inseparable part of the commitment and confidentiality agreement signed by both parties.

Sao Paulo, June $8^{\text {th }}, 2015$.

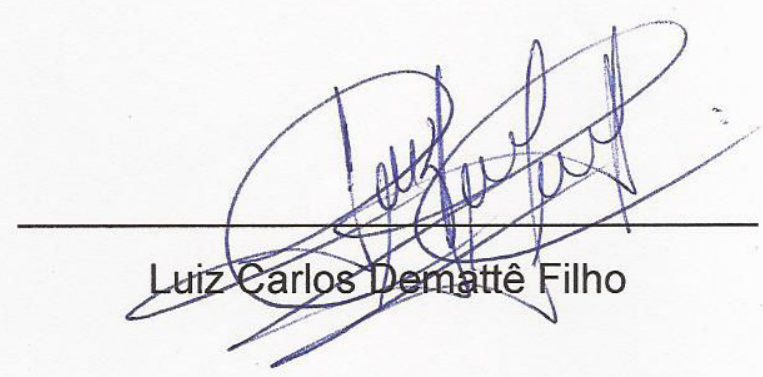




\section{Bibliography}

Adelman, M. A. (1949). The large firm and its suppliers. The Review of Economics and Statistics, 113-118.

Agrawal, D., \& Lal, R. (1995). Contractual arrangements in franchising: an empirical investigation. Journal of Marketing Research, 213-221.

Alchian, A. A., \& Demsetz, H. (1972). Production, information costs, and economic organization. The American economic review, 777-795.

Anderson, E., Day, G.S. \& Rangan, V.K. (1997) Strategic channel design, Sloan Management Review, 38(4): 59-69.

Anderson, E., \& Schmittlein, D. C. (1984). Integration of the sales force: an empirical examination. The Rand Journal of Economics, 385-395.

Argyres, N., \& Liebeskind, J. (1999). Contractual commitment, bargaining power and governance inseparability: incorporating history into transaction cost theory. Academy of Management Review, 24(1), 49-63.

Arrow, K. J. (1963). Uncertainty and the welfare economics of medical care.The American economic review, 941-973.

Arthur, W. B. (1988). Self-reinforcing mechanisms in economics. The economy as an evolving complex system, 5, 9-31.

Arthur, W. B. (1989). Competing technologies, increasing returns, and lock-in by historical events. The economic journal, 116-131.

Azevedo, P. F., \& Silva, V. L. (2001, September). Contractual mix analysis in the Brazilian franchising. In Fifth Conference of the International Society for New Institutional Economics (ISNIE), Berkeley-CA.

Azevedo, P. F., \& Silva, V. L. (2007). Governance inseparability in franchising: Multi-case study in France and Brazil. In Economics and Management of Networks (pp. 97-115). Physica-Verlag HD.

Azevedo, P. F., \& Silva, V.L.S. (2012a). Os opostos se completam! Revisando a teoria econômica sobre mix contractual (ou formas plurais). In: Silva, V.L.S. \& Azevedo, P. F. (Orgs.). Teoria e prática do franchising: Estratégia e organização de redes de franquias. São Paulo: Atlas, 2012a. Cap. 9. 
Azevedo, P. F., \& Silva, V.L.S. (2012b). Um novo olhar! A proposta de interdependência estratégica. In: Silva, V.L.S. \& Azevedo, P. F. (Orgs.). Teoria e prática do franchising: Estratégia e organização de redes de franquias. São Paulo: Atlas, 2012b. Cap. 13.

Bai, C. E., \& Tao, Z. (2000). Contract Mixing in Franchising as a Mechanism for Public Good Provision. Journal of Economics \& Management Strategy, 9(1), 85-113.

Baker, G., Gibbons, R. \& K. Murphy (2008). "Strategic alliances: bridges between islands of conscious power". Journal of the Japanese and International Economics, 22, 146-163.

Baker, G. P.; Gil, R. (2013). Clinical papers in Organizational Economics. In: Gibbons, R. \& Roberts, J. The Handbook of Organizational Economics. (pp.193-212) Princeton, NJ: Princeton University Press.

Balakrishnan, S. and B. Wernerfelt (1986). Technical change, competition, and vertical integration, Strategic Management Journal, 7(4), pp. 347-359.

Barney, J. (1991). Firm resources and sustained competitive advantage. Journal of management, 17(1), 99-120.

Barzel, Y. (1982). Measurement cost and the organization of markets. Journal of law and economics, 27-48.

Bradach, J. L., \& Eccles, R. G. (1989). Price, authority, and trust: From ideal types to plural forms. Annual review of sociology, 97-118.

Brickley, J. A., \& Dark, F. H. (1987). The choice of organizational form the case of franchising. Journal of financial economics, 18(2), 401-420.

Brickley, J. A., Dark, F. H., \& Weisbach, M. S. (1991). An agency perspective on franchising. Financial Management, 27-35.

Cannon, J. P., Achrol, R. S., \& Gundlach, G. T. (2000). Contracts, norms, and plural form governance. Journal of the Academy of Marketing Science, 28(2), 180-194.

Carney, M., \& Gedajlovic, E. (1991). Vertical integration in franchise systems: agency theory and resource explanations. Strategic Management Journal, 12(8), 607-629.

Caves, R. E., \& Murphy, W. F. (1976). Franchising: Firms, markets, and intangible assets. Southern Economic Journal, 572-586.

Carlton, D. W. (1979). Vertical integration in competitive markets under uncertainty. The Journal of Industrial Economics, 189-209.

Cliquet, G., \& Pénard, T. (2012). Plural form franchise networks: a test of Bradach's model. Journal of Retailing and Consumer Services, 19(1), 159-167.

Coff, R. W. (1999). When competitive advantage doesn't lead to performance. Organization Science, 10(2), 119-133. 
Cohen, W. M., \& Levinthal, D. A. (1990). Absorptive capacity: a new perspective on learning and innovation. Administrative science quarterly, 128-152.

Combs, J. G., \& Ketchen, D. J. (2003). Why do firms use franchising as an entrepreneurial strategy?: A meta-analysis. Journal of Management, 29(3), 443-465.

Dahlstrom, R., \& Nygaard, A. (1999). An empirical investigation of ex post transaction costs in franchised distribution channels. Journal of marketing Research, 160-170.

Dant, R. P., Paswan, A. K., \& Kaufman, P. J. (1996). What we know about ownership redirection in franchising: A meta-analysis. Journal of Retailing, 72(4), 429-444.

Dant, R. P., \& Schul, P. L. (1992). Conflict resolution processes in contractual channels of distribution. The Journal of Marketing, 38-54.

Darr, E. D., Argote, L., \& Epple, D. (1995). The acquisition, transfer, and depreciation of knowledge in service organizations: Productivity in franchises. Management science, 41(11), 1750-1762.

David, P. A. (1985). Clio and the Economics of QWERTY. The American economic review, 332-337.

Demattê Filho, L.C. (2004) Aditivos em dietas para frangos de corte criados em sistema alternativo. Masters thesis: Faculdade de Medicina Veterinária e Zootecnia, Universidade Estadual Paulista, Botucatu.

Demattê Filho, L.C. (2014) Sistema agroalimentar da avicultura fundada em princípios da Agricultura Natural: multifuncionalidade, desenvolvimento territorial $e$ sustentabilidade. Doctoral dissertation: Escola Superior de Agricultura Luiz de Queiroz, Piracicaba.

Dieese. Departamento Intersindical de Estatísticas e Estudos Econômicos (2006). Nota à imprensa, 09 de Maio de 2006. Retrieved from: < www.dieese.org.br/analiseicv/2006/2006004GripeAviaria.pdf $>$ on 21/09/2015.

Duhacheck, A.; Coughlan, A. T \& Iacobucci, D. (2005). Results on the standard error of the coefficient Alpha Index of reliability. Marketing Science, Vol. 24, No. 2, pp. 294-301.

Dutta, S., Bergen, M., Helde, J. B., \& John, G. (1995). Understanding dual distribution: the case of reps and house accounts. JL Econ. \& Org., 11, 189.

Dyer, J. H., \& Singh, H. (1998). The relational view: cooperative strategy and sources of interorganizational competitive advantage. Academy of management review, 23(4), 660679.

Eisenhardt, K. M. (1989). Building theories from case study research. Academy of management review, 14(4), 532-550.

Eisenhardt, K. M., \& Graebner, M. E. (2007). Theory building from cases: opportunities and challenges. Academy of management journal, 50(1), 25-32. 
Fladmoe-Lindquist, K., \& Jacque, L. L. (1995). Control modes in international service operations: The propensity to franchise. Management Science, 41(7), 1238-1249.

Foss, N. (2005). Strategy, economic organization, and the knowledge economy: the coordination of firms and resources. Oxford University Press.

Gallini, N. T., \& Lutz, N. A. (1992). Dual distribution and royalty fees in franchising. Journal of Law, Economics, \& Organization, 471-501.

Gibbons, R., J. Roberts (eds.) (2013). Handbook of Organizational Economics, Princeton University Press.

Gillis, W. E., Combs, J. G., \& Ketchen, D. J. (2014). Using Resource-Based Theory to Help Explain Plural Form Franchising. Entrepreneurship Theory and Practice, 38(3), 449472.

Grossman, S. J., \& Hart, O. D. (1986). The costs and benefits of ownership: A theory of vertical and lateral integration. The Journal of Political Economy, 691-719.

Harrigan, K.R. (1984) Formulating vertical integration strategies, Academy of Management Review, 9(4): 638-52.

Harrigan, K. R. (1986). Matching vertical integration strategies to competitive conditions. Strategic Management Journal, 7(6), 535-555.

He, D., \& Nickerson, J. A. (2006). Why do firms make and buy? Efficiency, appropriability and competition in the trucking industry. Strategic Organization,4(1), 43-69.

Heide, J. B. (1994). Interorganizational governance in marketing channels. The Journal of Marketing, 71-85.

Heide, J. B. (2003). Plural governance in industrial purchasing. Journal of Marketing, 67(4), $18-29$.

Heide, J. B., Kumar, A., \& Wathne, K. H. (2014). Concurrent sourcing, governance mechanisms, and performance outcomes in industrial value chains. Strategic Management Journal.

Holmstrom, B., \& Milgrom, P. (1991). Multitask principal-agent analyses: Incentive contracts, asset ownership, and job design. Journal of Law, Economics, \& Organization, 24-52.

Hunt, S. D. (1972). The socioeconomic consequences of the franchise system of distribution. The Journal of Marketing, 32-38.

Hunt, S. D. (1973). Trend toward company-operated units in franchise chains. Journal of Retailing, 49(2), 3-12. 
Hunt, S. D. (1977). Franchising: promises, problems, prospects. Journal of Retailing, 53(3), $71-84$

IBGE - Instituto Brasileiro de Geografia e Estatística (2013). Área territorial brasileira. Retrieved from: $<$ http://www.ibge.gov.br/home/geociencias/cartografia/default_territ_area.shtm $>$ on $08 / 07 / 2015$.

Jacob, J. (2015). Raising chickens for egg production. Retrieved from: $<$ http://www.extension.org/pages/71004/raising-chickens-for-eggproduction\#.VX7cFhNViko> on 15/06/2015.

Jacobides, M. G., \& Hitt, L. M. (2005). Losing sight of the forest for the trees? Productive capabilities and gains from trade as drivers of vertical scope. Strategic Management Journal, 26(13), 1209-1227.

Jensen, M. C., \& Meckling, W. H. (1976). Agency Costs and the Theory of the Firm. Journal of Financial Economics, 3(4), 305-360.

John, G., \& Weitz, B. A. (1988). Forward integration into distribution: an empirical test of transaction cost analysis. Journal of Law, Economics, \& Organization, 337-355.

Klein, B., Crawford, R. G., \& Alchian, A. A. (1978). Vertical integration, appropriable rents, and the competitive contracting process. Journal of law and economics, 297-326.

Knight, F. H. (1921). Risk, uncertainty and profit. New York: Hart, Schaffner and Marx.

Kraaijenbrink, J., Spender, J. C., \& Groen, A. J. (2010). The resource-based view: a review and assessment of its critiques. Journal of management, 36(1), 349-372.

Kranz, S., \& Lewin-Solomons, S. B. (2008). Decision structures in franchise systems of the plural form (No. 2008, 8). Bonn econ discussion papers.

Krzeminska, A. (2008). Determinants and Management of make-and-buy: and extension to TCE. Wiesbaden: Gabler.

Krzeminska, A., Hoetker, G., \& Mellewigt, T. (2013). Reconceptualizing plural sourcing. Strategic Management Journal, 34(13), 1614-1627.

Lafontaine, F. (1992). Agency theory and franchising: some empirical results. Rand Journal of Economics, 23(2), 263-283.

Lafontaine, F., \& Kaufmann, P. J. (1994). The evolution of ownership patterns in franchise systems. Journal of Retailing, 70(2), 97-113.

Lafontaine, F., \& Shaw, K. L. (2005). Targeting managerial control: evidence from franchising. RAND Journal of Economics, 131-150.

Lafontaine, F., \& Slade, M. E. (1997). Retail contracting: Theory and practice. The Journal of Industrial Economics, 45(1), 1-25. 
Lafontaine, F., \& Slade, M. (2007). Vertical integration and firm boundaries: the evidence. Journal of Economic Literature, 629-685.

Lal, R. (1990). Improving channel coordination through franchising. Marketing Science, 9(4), 299-318.

Lee, E., \& Staelin, R. (1997). Vertical strategic interaction: Implications for channel pricing strategy. Marketing Science, 16(3), 185-207.

Levy, D. (1985). The transaction cost approach to vertical integration: An empirical examination, Review of Economics and Statistics, 67, pp. 438-445.

Lewin-Solomons, S. (1998). The plural form in franchising: a synergism of market and hierarchy. Unpublished manuscript, Cambridge University and Iowa State University.

Lewin-Solomons, S. B. (1999). Innovation and authority in franchise systems: an empirical exploration of the plural form. Department of Applied Economics, University of Cambridge.

Lillis, C. M., Narayana, C. L., \& Gilman, J. L. (1976). Competitive advantage variation over the life cycle of a franchise. The Journal of Marketing, 77-80.

McAfee, R. P., \& Schwartz, M. (1994). Opportunism in multilateral vertical contracting: Nondiscrimination, exclusivity, and uniformity. The American Economic Review, 210230.

MacMillan, I. C., C. Hambrick \& J. M. Pennings (1986). Uncertainty reduction and the threat of supplier retaliation: Two views of the backward integration decision, Organizational Studies, 7(3), pp. 263-277.

Mahoney, J. T. (1992). The choice of organizational form: vertical financial ownership versus other methods of vertical integration. Strategic Management Journal, 13(8), 559-584.

Martin, R. E. (1988). Franchising and risk management. The American Economic Review, 954-968.

Meiseberg, B. (2013). The prevalence and performance impact of synergies in the plural form. Managerial and Decision Economics, 34(3-5), 140-160.

Ménard, C. (2004). The economics of hybrid organizations. Journal of Institutional and Theoretical Economics (JITE)/Zeitschrift für die gesamte Staatswissenschaft, 345-376.

Ménard, C. (2013). Plural Forms of Organization: Where do we stand?. Managerial and Decision Economics, 34(3-5), 124-139.

Ménard, C.; Saes, M. S. M.; Silva, V. L. S.; Raynaud, E. (2014) Challenges to economic organization: plural forms. São Paulo: Atlas. 
Michael, S. C. (2000). Investments to create bargaining power: the case of franchising. Strategic Management Journal, 21(4), 497-514.

Milgrom, P. R., \& Roberts, J. (1995). Complementarities and fit: strategy, structure and organizational change in manufacturing. Journal of Accounting and Economics, 19, 179-208.

Milgrom, P. R., \& Roberts, J. (1992). Economics, organization and management . Englewood Cliffs, NJ: Prentice-hall.

Minkler, A. P. (1990). An empirical analysis of a firm's decision to franchise. Economics Letters, 34(1), 77-82.

Moriarty, R. T., \& Moran, U. (1990). Managing Hybrid i Viarl< eting Systems.Harvard Business Review.

Mols, N. P. (2000). Dual channels of distribution: a transaction cost analysis and propositions. The International Review of Retail, Distribution and Consumer Research, 10(3), 227-246.

Mols, N. P. (2010). Economic explanations for concurrent sourcing. Journal of Purchasing and Supply Management, 16(1), 61-69.

Mols, N. P., Hansen, J. R., \& Villadsen, A. R. (2012). Plural governance: The effect of internal production on supplier performance. Industrial Marketing Management, 41(5), 874-885.

Monteverde, K., \& Teece, D. J. (1982). Supplier switching costs and vertical integration in the automobile industry. The Bell Journal of Economics, 206-213.

Nickerson, J. A., \& Silverman, B. S. (2003). Why aren't all Truck Drivers Owner-Operators? Asset Ownership and the Employment Relation in Interstate for-hire Trucking. Journal of Economics \& Management Strategy, 12(1), 91-118.

Norton, S. W. (1988). An empirical look at franchising as an organizational form. Journal of Business, 197-218.

Oxenfeldt, A. R., \& Kelly, A. O. (1969). Will successful franchise systems ultimately become wholly-owned chains. Journal of Retailing, 44(4), 69-83.

Ozanne, U.B.; Hunt, S.D. (1971). The economic effects of franchising. In: US Senate Select Committee on Small Business, US Government Printing Office, Washington, D.C,

Parmigiani, A. (2007). Why do firms both make and buy? An investigation of concurrent sourcing. Strategic Management Journal, 28(3), 285-311.

Parmigiani, A., \& Mitchell, W. (2009). Complementarity, capabilities, and the boundaries of the firm: the impact of within firm and interfirm expertise on concurrent sourcing of complementary components. Strategic Management Journal, 30(10), 1065-1091. 
Pénard, T., Raynaud, E., \& Saussier, S. (2003). Dual distribution and royalty rates in franchised chains: An empirical analysis using French data. Journal of Marketing Channels, 10(3-4), 5-31.

Portal do Franchising (2015). Franquia - Bob's alimentos. Retreived from: < http://www.portaldofranchising.com.br/franquia-bobs-alimentacao>.

Porteus, E. L., \& Whang, S. (1991). On manufacturing/marketing incentives. Management Science, 37(9), 1166-1181.

Puranam, P., Gulati, R., \& Bhattacharya, S. (2013). How much to make and how much to buy? An analysis of optimal plural sourcing strategies. Strategic Management Journal, 34(10), 1145-1161.

Rangan, V.K., Corey, E.R. \& Cespedes, F. (1993) Transaction cost theory: inferences from clinical field research on downstream vertical integration, Organization Science, 4(August): 454-77.

Robertson, T. S., \& Gatignon, H. (1998). Technology development mode: a transaction cost conceptualization. Strategic Management Journal, 19(6), 515-531.

Rothaermel, F. T., Hitt, M. A., \& Jobe, L. A. (2006). Balancing vertical integration and strategic outsourcing: effects on product portfolio, product success, and firm performance. Strategic Management Journal, 27(11), 1033-1056.

Russo, M. V. (1992). Power plays: Regulation, diversification, and backward integration in the electric utility industry. Strategic Management Journal, 13(1), 13-27.

Shelanski, H. A., \& Klein, P. G. (1995). Empirical research in transaction cost economics: a review and assessment. Journal of Law, Economics, \& Organization, 335-361.

Scott, F. A. (1995). Franchising vs. company ownership as a decision variable of the firm. Review of industrial organization, 10(1), 69-81.

Sorenson, O., \& Sørensen, J. B. (2001). Finding the right mix: Franchising, organizational learning, and chain performance. Strategic Management Journal, 22(6-7), 713-724.

Stump, R. L., \& Kim, S. K. (2015, January). Plural Governance in Industrial Purchasing: An Exploratory Study of Combinations in Actual Use. In Proceedings of the 2008 Academy of Marketing Science (AMS) Annual Conference (pp. 156-156). Springer International Publishing.

Szulanski, G., \& Jensen, R. J. (2006). Presumptive adaptation and the effectiveness of knowledge transfer. Strategic Management Journal, 27(10), 937-957.

Veugelers, R., \& Cassiman, B. (1999). Make and buy in innovation strategies: evidence from Belgian manufacturing firms. Research policy, 28(1), 63-80. 
Walker, G., \& Weber, D. (1984). A transaction cost approach to make-or-buy decisions. Administrative science quarterly, 373-391.

Walker, G., \& Weber, D. (1987). Supplier competition, uncertainty, and make-or-buy decisions. Academy of Management journal, 30(3), 589-596.

Williamson, O.E. (1985). The Economic institutions of capitalism: firms, markets and relational contracting, New York, Free Press.

Williamson, O.E. (1991). "Comparative economic organization: the analysis of discrete structural alternatives”, Administrative Science Quarterly, 36(2), 269-296.

Williamson, O. E. (1996). The mechanisms of governance. Oxford University Press.

Winter, S. G., \& Szulanski, G. (2001). Replication as strategy. Organization science, 12(6), 730-743.

Yin, X., \& Zajac, E. J. (2004). The strategy/governance structure fit relationship: Theory and evidence in franchising arrangements. Strategic management journal, 25(4), 365-383.

Zylbersztajn, D. Measurement Costs and Governance: bridging perspectives of transaction cost economics., 2008. In seminar on Internal Organization, Cooperative Relations among firms and competitiveness. Lucca, Italy, organized by the Universitá di Pisa. Lucca, Italy.

Zylbersztajn, D., \& Nogueira, A. C. L. (2002). Estabilidade e difusão de arranjos verticais de produção: uma contribuição teórica. Economia e Sociedade, 11(2), 329-346. 


\section{Hétérogénéité des formes plurielles: une approche par les coûts de transaction revisée.}

Abstract

Cette thèse est composée de quatre chapitres et analyse une régularité empirique très mal connue et très peu analysée : les «formes organisationnelles plurielles ». Dans le premier chapitre, j'examine les diverses tentatives de théoriser les formes plurielles et comment ce domaine a évolué au fil du temps. Cela me permet d'identifier deux variables qu'on retrouve au cœur des idées exprimées dans ces tentatives pour expliquer l'existence et la stabilité des formes plurielles : la spécificité des actifs ainsi que les facteurs d'incertitude. Néanmoins, ces variables sont restées très mal explorées, ce qui pointe la nécessité de nouvelles contributions théoriques sur ce sujet. Dans le deuxième chapitre, je cherche à comprendre ce qui explique la variété des formes plurielles. Je propose un modèle théorique intégrant la spécificité des actifs et l'incertitude pour pronostiquer l'existence des formes plurielles et non plurielles. Ensuite, je souligne que les formes plurielles sont hétérogènes et je construis des hypothèses mettant en relation différents types d'incertitude avec des formes plurielles différentes. Dans les deux chapitres suivants, le modèle théorique et les hypothèses sont confrontés à des données empiriques qualitatives. Le troisième chapitre confronte le modèle théorique à une étude de cas clinique menée au sein d'une entreprise, l'entreprise Korin (Brésil), qui produit et vend divers produits bios. Enfin dans le chapitre quatre, le modèle théorique et les hypothèses sont confrontés à des données recueillies à partir d'une enquête sur l'approvisionnement en 'inputs' auprès de 24 entreprises opérant dans le secteur agricole brésilien. Je trouve dans ces deux articles des concordances fortes à l'appui de mon modèle et des hypothèses que j'en ai dérivées, ce qui ouvre la voie à de nouvelles recherches.

Mots-clés : coûts de transaction, formes organisationnelles plurielles, incertitude, spécificité des actifs.

\section{Heterogeneity of plural forms: a revised transaction cost approach}

\section{Abstract}

This dissertation is composed of four chapters and addresses an empirical regularity about which very little is known: "plural forms". In the first chapter, I intend to verify what has been theorized about plural forms and how this field has evolved over time. I identified two variables that underlie most of the theoretical explanations for the existence and stability of plural forms: asset specificity and uncertainty. However, these variables are very seldom explored, which points towards the need for novel contributions. In the second chapter, I am concerned with explaining the variety of plural form manifestations. I built a theoretical model integrating asset specificity and uncertainty to predict plural and non-plural forms. Next, I stressed that plural forms are heterogeneous and built hypotheses relating different types of uncertainty to different types of plural forms. In the next two chapters, I empirically confront my theoretical model and hypotheses with qualitative data. In the third chapter, I confront my model by performing an embedded clinical case study on the Korin company (in Brazil), which produces and commercializes multiple organic products; while in the final chapter, I intend to empirically confront both my theoretical model and my hypotheses and survey the procurement of inputs by 24 companies operating in the Brazilian Agribusiness sector. I find support for my model and for my hypotheses on both of these papers, indicating a path for further analyses.

Keywords: transaction cost, plural forms, uncertainty, asset specificity. 